\title{
NIVEIS DE CALCÁRIO E DE POTÁSSIO EM UM LATOSSOLO VERMELHO-AMARELO PARA QUATRO CULTIVARES DE ALFAFA
}

MONICA SUTTON

Zootecnista

Qrientador: Prof. Dr. FRANCISCO ANTONIO MONTEIRO

Dissertaçéco apresentada a Escola Superior de Agricultura "Luiz de Queiroz", da Universidade de Sáo Paulo, para obtençáo do titulo de de Mestre em Agronomia. Ároa de concentraçáo: Ciencia Animal e Pastagens.

\author{
P I R A C I C A B A \\ Estado de 8so Paulo - Brasil \\ Dezembro - 1993
}


Ficha catalografica prepargda pela seça de Livros da Divisão de Bitilioteca e Documentaça - FCLQ/USF

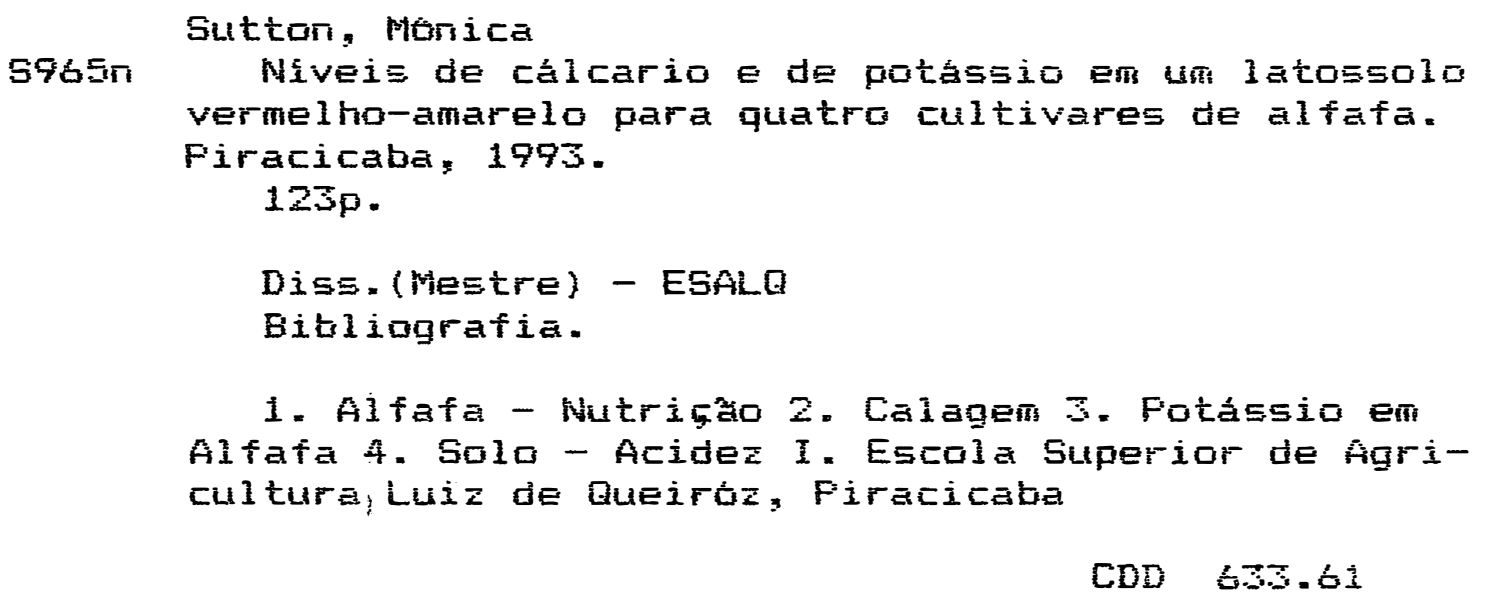




\section{NIVEIS DE CALCÁRIO E DE POTÁSSIO EM UM LATOSSOLO \\ VERMELHO-AMARELO PARA QUATRO CULTIVARES DE ALFAFA}

MONICA GUTTON

Aprovada $=04.02 .94$

Comissato julgadora:

Prof. Dr. Francisco Antonio Monteiro ESALQ/USP

Dr. Herbert Barbosa de Mattos IZ/SAA

Prof. Dr. Quirino A. de Camargo Carmello ESALQ/USP

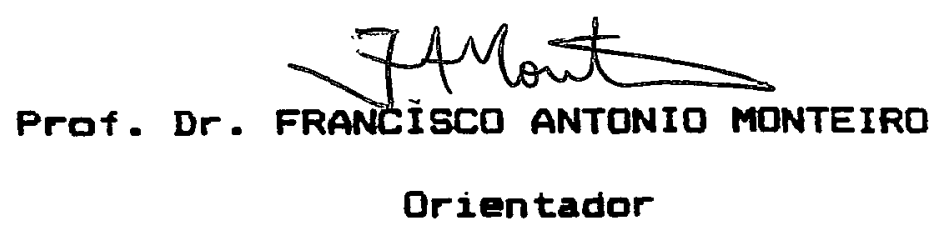

Orientador 
iii

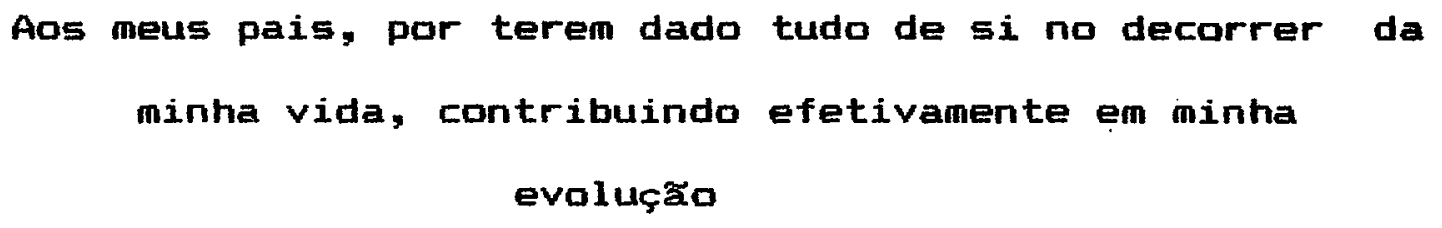

Ofereço

A minha irma, pela eterna

amizade

A meus afilhados, Manuela e Daniel, mensageiros do céu 


\title{
AGRADECIMENTOS
}

\author{
São apresentados os sinceros agradecimentos as \\ seguintes pessoas e instituiços:
}

Ao Prof. Dr. Francisco Antonio Monteiro, pela orientação, disposição amizade dedicados à nossa pessoa.

Ao Prof. Dr. Raul Machado Neto, pela compreensão e afeto que sempre nos distinguiu.

Aas dacentes da Escola Superior de Agricultura "Luiz de Queiroz" - USP, pelos cursos oferecidos.

Ao Conselho Nacional de Pesquisa (CNPq), pela concessão de bolsa de estudo.

Ao Jockey Club de São Paulo, pelo financiamento da pesquisa, demonstrando interesse pela ciéncia.

Ao Dr. Luiz Alberto Marinho, pelo apoio e confiança indispensaveis en nosso trabalho.

Aos fieis amigos Marca Antonio, Fablola, Laranja, Carlos Eduardo, Valeria e Soraia pela compreensao dedicada nos momentos mais dificeis.

Aos laboratoristas, Fernando Eder Ré, Nivanda Maria de Moura, Mirtes Ventura Sesso, Lurdes Ap. Dário de González, Edinéia Cristina S. Mondoni e Lúcia H. S. Pavan Forti, pela colaboração na execução de análises químicas de solo e de plantas. 
A Fatricia Pessini pela dedicação indispensável na parte experimental do nosso trabalho.

A bibliotecária Kátia M. de Andrade Ferraz, pela ajuda na citação de literatura pela doçura dispensada a todos.

En especial ao Zago, pelo companheirismo, carinho e paciéncia indispensaveis para conclusão deste trabalho.

$E$ a todos que, de alguma forma, contribulram à realização do presente trabalho. 
SUMARID

Pagina

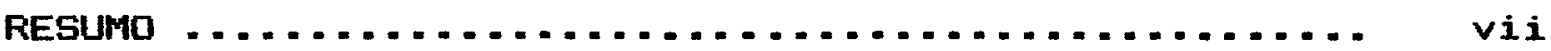

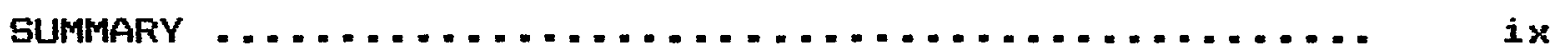

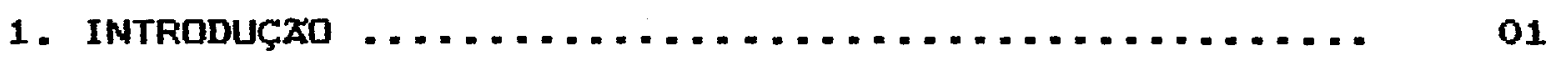

2. REVISÃ dE LITERATURA ....................... 04

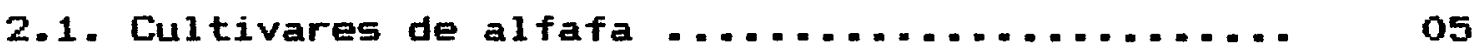

2.2. Acidez do solo e sua correção para alfafa .... 09

2.3. Potássio e a nutrição da alfafa ............ 17

3. MATERIAL E METODDS .......................... 31

3.1. Forrageira ............................ 31

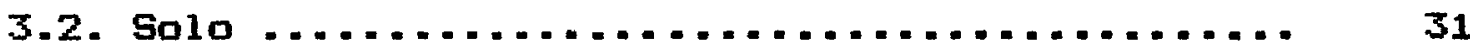

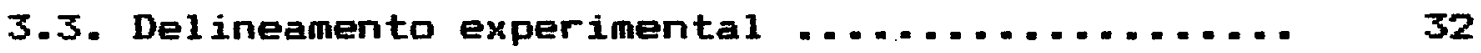

3.4. Calagem e incubação da terra ............. 32

3.5. Plantio e condução do experimento .......... 33

3.6. Análises químicas das plantas ............ 35

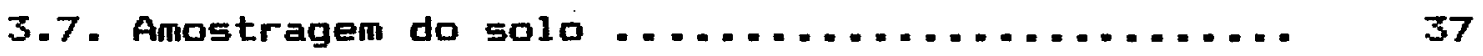

3.8. Análises químicas do solo ................ 37

3.9. Análises estatísticas ................... 39

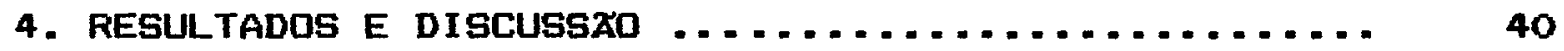

4.1. Efeitos de calcário e potássio no solo ....... 40

4.2. Efeitos na planta ...................... 55

4.2.1. Produção de matêria seca e nitrogenio na planta 55

4.2.2. Teqres de macro e micronutrientes na planta . = 75

5. CONCLUSOES ................................ . . 107

REFERENCIAS BIBLIGGRAFICAS ...................... 109 


\section{NIVEIS DE CALCÁRIO E DE POTÁSSIO EM UM LATOSSOLO \\ VERMELHO-AMARELO PARA QUATRO CULTIVARES DE ALFAFA}

Autor: MONICA SUTTON

Orientador: PROF. DR. FRANCISCO ANTONIO MONTEIRO

RESUMO

a presente trabalho foi desenvolvido com o objetivo de estudar a influencia de niveis de calcário e de adubação potássica na produção de matéria seca, na quantidade total de nitrogênio e na composição mineral de quatro cultivares de alfafa (Hedicago sativa L.).

o experimento foi conduzido en vasos, en casa de vegetação situada na Escola Superior de Agricultura "Luiz de Queiroz", en Piracicaba, Estado de Săo Paulo. Utilizou-se um solo classificado como Latossolo Vermelho-Amarelo fase argilosa. Foram testados em um esquema fatorial $4 \times 3 \times 4$, quatro niveis de calcário 105950 ; 1900 e 2850 quilogramas de calcário dolomitico por hectare), trés niveis de adubação potássica (0; 100 e 300 quilogramas de potássio por hectare) e quatro cultivares de alfafa (Crioula, Moapa, Florida 77 e CUF 101). Ds quarenta e oito tratamentos foram dispostos em blocos ao acaso, com quatro repetiçశes. 
A aplicação do calcário dolomítico foi realizada quarenta e oito dias antes do plantio da alfafa, enquanto o potássio foi aplicado na forma de soluçăo três dias após o plantio. Realizou-se uma adubação básica, em todos os vasos, com fósforo, enxofre, boro, cobre, molibdénio e zinco.

Setenta dias após o plantio, efetuou-se o primeiro corte enquanto a segundo corte foi realizado entre cento e quatro e cento e onze dias apos o plantio.

Os cultivares de maior produção de materia seca no primeiro corte foram Florida 77 e CUF 101, os quais se igualaram aos cultivares Crioula e Maapa no segundo corte. a cultivar florida 77 teve menor produção de materia seca de raizes que os demais cultivares.

Al teraçજ̄es consideráveis nas concentraçð̋es de macro e micronutrientes na alfafa foram verificadas, em função das aplicaçós de calcário dolomitico e de cloreto de potássio.

As máximas produçớes de materia seca e quantidades totais de nitrogenio, foram atingidas com os niveis de calcário dolomitico entre 2200 e $2750 \mathrm{~kg} / \mathrm{ha}$, correspondendo a uma saturação por bases de 54 e 67,5\%.Para a potássio esses pontos de máximo estiveram entre 100 e $185 \mathrm{~kg}$ K/ha.

Sintomas visuais de deficiencia de potassio foram observados na alfafa desenvolvida nos tratamentos que não receberam esse nutriente na adubaçăo. 


\section{LIME AND POTASSIUM RATES IN A RED YELLOW LATOSOL FOR ALFALFA FOUR CULTIVARS}

Author: MONICA SUTTON Adviser: PROF. DR. FRANCISCO ANTONIO MONTEIRO

SUMMARY

This study was undertaken to determine the effects of lime and potassium fertilization rates in the dry matter yield, in the total amount of nitrogen and in the mineral composition of four cultivars of alfalfa (Hedicago sativa L.).

The experiment was carried out in a greenhouse located at the Escola Superior de Agricultura "Luiz de Queiroz", in Piracicaba, State of Săo Paulo. A clay Red Yel low Latosol was placed in the plastic pots. A $4 \times 3 \quad \times 4$ factorial was used. Four lime rates $10 ; 950 ; 1900$ and 2850 kg dolomitic limestone/ha), three potassium fertilizer rates $10 ; 100$ and $300 \mathrm{~kg} \mathrm{~K} / \mathrm{ha}$ ) and four alfalfa cultivars (Crioula, Moapa, Florida 77 and CUF 101) were studied. The forty-eight treatments were set in a randomized complete block design; with four replications.

Liming was done forty-eight days before sowing whereas potassium chloride was applied as water solution 
three days after legume sowing. A basic fertilization with phosphorus, sulphur, boron, copper, molybdenum and zinc was performed.

Plants were cut seventy days after sowing and allowed to regrow. A second harvest was done at 104 to 111 days after soucing and allowed to regrow.

Florida 77 and CUF 101 cultivars had the highest dry matter herbage yield at the first harvest, but all the cultivars had similar yields at the second harvest. Florida 77 cultivar showed the lowest root dry matter.

Changes in nutrient concentration in the plant tissue, as a result of lime and potassium applications, were evident.

Maximum forage yield and total amount of nitrogen were attained with dolomitic limestone rate between 2200 and $2750 \mathrm{~kg} / \mathrm{ha}$, which corresponded to soil basis saturation between 54 and $67,5 \%$. For potassium these maximum were reached between 100 and $185 \mathrm{~kg} \mathrm{~K} / \mathrm{ha}$.

Visual symptoms of potassium deficiency were observed in plants grawn in the treatments that did not receive potassium fertilization. 


\section{INTRODUÇAO}

0 estabelecimento e a manutenção de plantas forrageiras em pastagens depende em grande parte da fertilidade do solo. A baixa fertilidade dos solos destinados à exploração agropecuária é un dos motivos da baixa produtividade das pastagens na maior parte do território brasileiro.

A alfafa (Nedicago sativa L.), que \& uma leguminosa forrageira rica en protelnas, sais minerais, vitaminas, energia bruta, alem de conter cálcio, fósforo, betacaroteno e outros elementos importantes para a nutriçăo animal, tem sido amplamente cultivada nas mais variadas partes do mundo. Originaria do Oriente Médio, \& uma planta forrageira que conquistou os cinco continentes, e hoje já ultrapassa os $30 \mathrm{mi} 1$ hợes de hectares cultivados (MICHAUD et al., 1988).

0 centro geográfica de origem frequientemente mencionado para a alfafa é a Irã (BOLTON et al., 1972).

Essa leguminosa forrageira entrou no Brasil no seculo passado pelo Rio Grande do Sul, atraves da imigraça europeia. Sofreu ao longo dos anos processos de adaptaçăo à 
condiçơes climáticas e edáficłs do sul do Brasil. Surgiu então, pelo processo de seleçăo natural, uma população de plantas com uma identidade genetica bastante estreita, que com o passar do tempo recebeu a nome de Criaula.

Naturalmente, um incremento nas produçôs das plantas deve-se à alguns fatores como: cultivares e/ou manejo da cultura; pragas e doenças; irrigação e a programa de fertilização. A obtenção de altas produtividades de alfafa conduz à remoção de elevadas quantidades de nutrientes, se comparadas com as culturas produtoras de grăos.

A busca de espécies e/ou cultivares, en função dos problemas de diferentes sistemas de produção, justifica a introdução de material genético previamente conhecido e ja consagrado em outras regibes.

Em se tratando de uma leguminosa forrageira de grande importancia justifica-se a tentativa de introduzi-la em regiós com solos ácidos de baixa fertilidade. Porém, nessas condiçoses, pela ocorrencia de excessos de aluminio e manganes na solução do solo e pela baixa disponibilidade de nutrientes minerais, tornam-se indispensáveis a correção da acidez do solo e a aplicação de fertilizantes para a obtençăo de sucesso no seu estabelecimento. Um dos fatores de produçăo, limitante ao desenvolvimento da alfafa e, sem dúvida, a ausencia de um programa de adubação compatível com suas necessidades e as caracteristicas edaficas regionais.

o objetivo do presente trabalho foi estudar o 
efeito de aplicaçơes de calcário e potássie sobre as caracteristicas químicas do solo, sobre a produção de matéria seca e a composição mineral de quatro cultivares da alfafa (Crioula: Moapa; Florida 77 e CuF 101) em um latossolo vermel ho-amarelo do Município de Campinas. 


\section{REVISAO DE LITERATURA}

As exigéncias de uma determinada espécie forrageira, quanto as qualidades do ambiente, devem ser consideradas na seleça da espécie para o local a que se destina. As condiçర̋es requeridas para o crescimento de uma espécie podem ser impróprias para outra (SIQUEIRA, 1987).

Pesquisas envolvendo a adubação da alfafa são escassas no Brasil, concentrando-se no fio Grande do Sul, o que possivelmente contribuiu para a definiçăo das recomendaçôes atuais de adubaçăo para essa forrageira naquele Estado (SIQUEIRA, 1987).

Geograficamente, a cultura da alfafa localiza-se no Sul do Brasil, particularmente na região do Norte do Paraná e parte do Rio Grande do Sul. o não cultivo en maior escala talvez se deva ao manejo inadequado do solo. 0 crescente interesse por sua utilização demanda cultivares adaptados as condiç̧es climaticas e as caracteristicas do 5010 dessa região (HONDA \& HONDA, 1990).

Pode-se considerar, que a fator solo $\&$ de fundamental importância no que diz respeito à produtividade e longevidade da cultura. 0 solo poderá ser alterado en suas 
propriedades quimicas e fisicas, atraves de tratos culturais, tais como calagem, adubação química e orgánica, sendo que a intensidade dessas práticas será função da fertilidade própria do solo, que poderá ser determinadas em principio, pela análise do solo (HONDA \& HONDA, 1990).

0 solo é um dos componentes de um ecossistema agricola que podem ser modificado mais facilmente pelo homem. Nos trópicos úmidos, há uma predominância de solos ácidos, e como a correça da acidez dos solos e feita atraves da calagem, lembra-se de imediato que ela é necessária para se obter boa produtividade das forrageiras. A necessidade de calagem vai depender da interação do solo com a especie forrageira.

a desenvolvimento inadequado da alfafa em solos ácidos tem sido motivo de muitas investigaçôes. Assim, nesta revisão de literatura serão enfocados aspectos relacionados a competição entre cultivares, aos fatores limitantes da produção da alfafa em solos ácidos, bem como a influência do calcário e da adubação potássica sobre a produção dessa forrageira.

\subsection{Cultivares de alfafa}

- Estado do Rio Grande do Sul possui uma população naturalmente selecionada de alfafa Crioula, que tem demonstrado uma série de vantagens e que já provou em muitos 
experimentos ser superior aos outros cultivares (SAIBRO et a1.. 1972; BASSOLS \& PAIM, 1978; MEDEIROS \& ZAMBFA, 1987).

A importância que tem essa cultura ao nivel mundial e principalmente a grande variabilidade que apresenta, permite adaptar-se às mais diversas regióes. Toda essa variabilidade encontra-se en algumas espécies de interesse agricola (DEL POZO, 1971), o que significa um grande número de cultivares e populaçర̃es adaptadas e selecionadas a cada situação.

Durante séculos, a alfafa sofreu adaptaçôes à novos ambientes, acompanhando a imigraçăo dos homens em diferentes zonas climaticas pelo mundo, havendo dificuldades no estabelecimento dos estandes, nas variadas condiçชes climáticas (HANSON, 1972).

Segundo SAIBRO (1985), nas últimas décadas foran desenvolvidas vários esforços integrados de instituiçช̌ses públicas e privadas, intensificando a pesquisa com a alfafa, principalmente, fora da região tradicional de cultivo da especie. Assim, várins trabalhos de avaliaçăo de cultivares foram realizados não só no Rio Grande do Sul, mas en outros Estados, como så Paulo e Ceará.

Num trabalho de competição entre onze cultivares de alfafa oriundos dos Estados Unidos, ARAUJO FILHO et al. (1971) obtiveram para o cultivar sonora rendimento medio anual de 32,15 toneladas de materia seca por hectare. Também destacaram-se os cultivares Moapa, African, 
AZSW $\cdots 17$ Indian que tiveram rendimentos médios anuais de 31,$0 ; 30,9 ; 30,4$ e 30,3 tha, respectivamente.

BASSOLS \& PAIM (1978) conduziram un estudo comparativo entre seis cultivares de alfafa introduzidas no Rio Grande do Sul, con a objetivo de comparar com o cultivar Crioula. Foram analisadas as produçßes de matéria seca e de proteina bruta, a relação caule/folha e as alturas médias dos cultivares cortados em dois estágios de crescimento (pré-crescimento e $50 \%$ de floração). Verificaram que o cultivar Crioula sobrepujou os demais na produção de matéria seca e de proteina bruta. Esse resultado concorda com a obtido por SAIBRO et al. (1972), onde tambem a cultivar Crioula foi superior en produção de matéria seca aos demais cultivares testados.

Segundo SAIBRo (1985), a identificaçăo de cultivares de alfafa adaptados e produtivos, para utilizaçăo nos solas ácidas corrigidas em seus aspectos de fertilidade, foi inicialmente, uma das preocupaçб̌es de vários pesquisadores do Rio Grande do Sul. En 1965 foram estabelecidos os primeiros estudos comparativos de cultivares de alfafa. A alfafa cultivar Crioula, apresentou rendimento de máteria seca superior em relação aos outros treze cultivares introduzidos em Gual ba e Montenegro.

Trabalhando con vinte e seis cultivares de alfafa, OLIVEIRA (1986) constatou que o cultivar Florida 77 destacou-se en produtividade, não diferenciando 
significativamente do CUF 101 e Moapa. No que se refere a sobrevivencia, observou que os cultivares florida 77, CUF 101 e Moapa apresentaram alta porcentagem de cobertura do solo no final do experimento. Também concluiu que os cultivares Florida 77, Cuf 101 e Crioula så equivalentes em qualidade nutricional.

No Estado de São Paulo, nos anos de 1984 e 1985, OLIVEIRA \& CORSI (1987), avaliaram a produçãa e a qualidade da forragem de vinte e seis cultivares de alfafa, entre elas, o cultivar Crioula. Obtiveram, num total de oito cortes, a produtividade média de matéria seca en todos as cultivares de 17,3 t/ha, onde destacou-se o cultivar florida 77, porém năo diferindo significativamente dos dezesseis de maior produtividade. 0 cultivar Crioula ficou en décimo-nono na ordem de rendimento, com uma produçăo media em oito cortes de 13,6 t/ha. Para o teor de protelna bruta da matéria seca, năo houve diferenças entre os cultivares florida 77, CuF 101, Moapa e Crioula, e a média foi de $20,6 \%$ de proteina bruta na materia seca.

MEDEIROS \& ZAMBRA (1987) em Augusto Pestana, na regiăo das Missชes (RS), Conduziram no perído de 1977 a 1981, um trabalho de avaliação do potencial de produçăo de dezesseis cultivares de alfafa comparados com alfafa Crioula. Os resultados obtidos mostraram a superioridade do cultivar Crioula sobre os demais. 
2.2. Acidez do solo e sua correçáo para alfiffa

Dentre as respostas de diversas espécies normalmente cultivadas na regiăo sul dos Estados Unidos, ADAMS \& PEARSON (1967) concluiram que a alfafa e a mais responsiva à calagen.

As respostas das culturas à calagem, dependem de fatores ligados à planta, ao solo e ao corretivo empregado, de tal modo que, quando esses fatores să corretamente considerados, obtém-se a máxima eficiencia com essa prática agricala. Segundo quAGgio (1985), vários métodos de laboratório têm sido empregados para determinar a necessidade de calagem em solos no Pals, entre os quais estão - critério baseado no teor de alumínio trocável, no método do tampão SMP e no metodo baseado na elevação da saturação por bases do salo.

A determinaçăo da necessidade de calagem para a elevação da saturaçăo por bases foi introduzida no laboratorio de rotina do Instituto Agronómico de Campinas, em 1983. Desde então vem sendo utilizada no Estado de sao Paula, com a vantagen principal estando na facilidade dos cálculos e na flexibilidade de adaptação para diferentes culturas, de acordo com as exigencias destas.

FREITAS \& PRATT (1969), estudando as respostas de tres leguminosas, entre as quais estava a alfafa, a aplicação de calcario en diversos solos acidos, obtiveram as 
maiwres medias de produçăo de materia seca de siratro (Hacroptiliua atropurpureu= D.C. CV. Siratra), em todos as solos, em pH 6,1 e os de Stylosanthes em pH 6,4. Com a alfafa obtiveram resposta ao calcário na faixa de $\mathrm{pH} 4,5$ a 6,0. Concordando com ADAMS \& PEARSON (1967), referiram-se aqueles autores a outros experimentos reportados na literatura com resposta da alfafa ao calcário desde pH 5,5 ate 6,5 .

ROBSDN \& LONERAGAN (1970) estudaram o efeito do pH e da concentração de cálcio da soluçăo do solo, através do crescimento e da absorção e distribuição de manganes em duas espécies anuais de Medicago comparadas com Trifoliua subterraneum L. Os resultados do experimento indicaram que ambas as espécies anuais de Medicago foram mais sensiveis a toxidez de manganés do que a de Trifoliuw. Essa maior sensibilidade pareceu estar relacionada à maior taxa de absorção e maior transporte de manganés das ralzes para a parte aérea da planta, en condiçס̋es de suprimento de luxo. Os autores sugeriram ainda, que a maior sensibilidade da Hedicago a toxidez de manganes deveria estar associada a baixa toleráncia ao encharcamento. Quanto ao calcio, ficou confirmado que seu acrescimo aliviou a toxidez de manganes, sendo possivel que os efeitos de calcio e pH na absorção e distribuição de manganés se confundiram com os efeitos da adsorça propriamente do que a absorçăo desse micronutriente. A magnitude do efeito do cálcio e do pH na absorção de 
manganes e na sua distribuição foi diferente para as diferentes espécies.

KORNELIUS (1972) estudau a influencia da calagem e das adubaçóes fosfatada e potássica na produção de materia seca da alfafa en seis solos do Rio Grande do Sul. Concluiu que a aplicação de calcário e de fósforo aumentaram significativamente $(P<0,01)$ a produção de matéria seca nos seis solos testados, enquanto que a potássio aumentou a produção de matéria seca da forragem apenas no Oxissolo Erexim.

Estudando a comportamento da alfafa cultivada em casa de vegetação, em seis tipos de solos ácidos, STAMMEL \& KORNELIUS (1973) concluíram que na auséncia de calcário, o cloreto de potássio causou redução no pH e aumento no teor de manganés tracável dos seis solos, aumentando a absorcão desse micronutriente pela alfafa. Sem calcário, a aplicaçăo de 400 $\mathrm{mg} \mathrm{K} 2 \mathrm{O} / \mathrm{kg}$ determinou aumentos de 22 a $103 \%$ no teor de manganés trocável do solo, enquanto que no tecido da alfafa aumentou de 19 a $68 \%$ dependendo do tipo de solo. A aplicação do calcario eliminou os efeitos negativos do cloreto de potássio, o que é um aspecto positiva, há necessidade de praticar a adubação potássica juntamente com a calagem.

McLEAN \& CARBONELL (1972) estudaram en casa de vegetação, as produçớes de matéria seca de setaria italica e Medicago sativa, utilizando cinco niveis de saturaçăo de ca Mg e dois niveis de potássio. A produçăo de alfafa nă foi 
afetada pela orden de saturação de Ca - Mg $M g$ s\% - Ca $75 \%$ e Mg 25\% - Ca 55\%). Entretanto, ocorreu resposta ao magnesio com o acréscimo inicial de magnésio e de cálcio de 3 e $18 \%$ para 5 e $75 \%$, respectivamente, e concomitantemente, o pH ( $\mathrm{H}_{2} \mathrm{O}$ ) passado de 5,4 para 6,8. Concluiran que o conteúdo de magnesio no tecido das plantas aumentou quando houve acréscimo na saturação de magnésio, porém $a$ acréscimo de potássio no solo diminuiu o teor de magnésio contido nos tecidos. Ressaltaram os autores, a titulo de precaução, que a aplicação de potássio pode ser em doses baixas, porém, com maior frequência, de tal forma que a conteúdo de magnesio na forragem se estabilize.

JOHN et al. (1972) utilizaram sete solos para estudos com alfafa e verificaram que cinco deles propiciaram incrementos significativos $(P<0,05)$ na produçăo de matéria seca da alfafa quando receberam calcário para atingir saturação por bases de 70\%, enquanto que, os outros dois solos responderam até a dose calculada para alcançar 100\%. Isso sugere que a elevação do pH para a neutralizaçăo do aluminio geralmente será suficiente para a maximização da produção de materia seca da alfafa.

JONES \& FREITAS (1970) estudaram respostas de quatro leguminosas tropicais à aplicaçßes de fósforo, potássio e calcáio nun latossolo vermelho-amarelo de campo cerrado. Encontraram resposta no aumento de produção de materia seca das leguminosas stylosanthes gracilis. 
Centrosena pubescens, Neonotonia Highitii e hacroptilium atropurpureum, desde $250 \mathrm{~kg}$ de Ca/ha até $1000 \mathrm{~kg}$ de Ca/ha. Doses mais elevadas de calcário resultaram em decréscimo de produção de materia seca. Foran ben distintas as curvas de respostas das quatro leguminosas a aplicação de calcário, indicando para cada uma das especies estudadas uma diferente necessidade de calcário. As respostas dessas leguminosas tropicais ao potássio não foram estatisticamente significativas $(P>0,05$ ). O efeito da aplicação de doses de cálcio e magnésio sobre o teor de potássio das plantas diminuiu com a aplicação de calcio e magnésio até cerca de $250 \mathrm{~kg}$ de Ca/has aplicaçós de calcário acima desse nivel pouco afetaran os niveis de potássio, porén aplicaçós de 1.000 e $2.000 \mathrm{~kg}$ Ca/ha voltaram a elevar os teores de potássio na planta.

Experimentos conduzidos por FREITAS \& PRATT (1969), en casa de vegetaçăo avaliaram as respostas de Medicago sativa, Macroptilium atropurpureun e stylosanthes gracilis à aplicacão de calcário em aito solos do Estado de să Paulo, sendo quatro latossolos e quatro podzolicos vermelho-amarelos. As respostas da alfafa ao calcario, em produção de materia seca, foran significativas ( $P<0,05$ ) em todos as solos. As produç̧̌s máximas de materia seca foram abtidas en todos os solos uo pH 6,4 ou acima, mas os maiores acréscimos de produção foram observados quando o pH foi elevado de 4,5 para 6,0 . Ds resultados, segundo os autores, 
sugeriram que aplicaç⿸es de calcário para obtenção de valores de pH acima de 6,0 seriam de pouca valia no caso da alfafa para a maioria desses solos. No caso de Stylosanthes a maior produção média correspondeu ao pH de 6,4 e para Macroptiliu. ao $\mathrm{pH} \mathrm{6,1} \mathrm{verificando-se} \mathrm{um} \mathrm{ligeiro} \mathrm{decréscimo} \mathrm{de} \mathrm{produçăo}$ quando a pH passou para 6,2. Ds autores recomendaram a aplicação de calcário para se quiser obter resultados satisfatórios com as trés leguminosas nos vârios tipos de salas.

Em tres solas do Rio Grande do sul (Erexim, Passo Fundo e Santo Angelo), o emprego do potássio mesmo na presença do fósforo, inibiu o crescimento da alfafa, segundo KORNELIUS (1972). Esse acentuado efeito depressivo sobre a produção de matéria seca desapareceu com o emprego do primeiro nivel de calcário. A aplicação de potássio com calcário proporcionou, en geral, uma grande resposta ma produção de alfafa, concordando com os dados de YoRk Jr. et al. (1954a) JACKSON et al. (1966) e SILVA \& STAMMEL (1969). A falta de resposta ou os efeitos depressivos da adiçăo de KCl ao solo sem calcário, está ligada a um aumento na disponibilidade de manganes no solo e a uma maior absorçăo desse micronutriente pelas plantas (KORNELIUS, 1972).

KORNELIUS (1972) estudando alfafa, concluiu que o pH foi decisivo para a produção de alfafa, a qual atingiu produçőes máximas de matéria seca entre pH 6,3 e 7,8, ressaltando que a elevação do pH acima de 6,5 causou 
deficiencia de micronutrientes nas plantas.

o trabalho de CRUZ \& STAMMEL (1978) teve por objetivo avaliar o efeito residual da calagem em salos cam diferentes teores de aluminio trocável e de diferentes classes texturais, atravess de modificaçợes em algumas propriedades quimicas e rendimentos de culturas. Ds solos utilizados foram Vacaria (argila pesada), Săo Jerónimo (franco argilo - arenoso) e Tupanciretã (areia franca). Decorridas 80 meses, os autores encontraram efeito residual da calagem avaliado através de análises químicas do solo e rendimentos das culturas, concluindo que corrigida a acidez, - potencial produtivo da alfafa nesses solos está relacionado com as distintas classes texturais.

SANZONOWICZ \& VARGAS (1980) estudaram o efeito de niveis de calcário e potássio na produção e composição quimica do stylosanthes guianensis em um latossolo vermelho-escuro do cerrado. Efetuados tres cortes, obtiveram uma produção máxima de matéria seca com $270 \mathrm{~kg} \mathrm{K/ha} \mathrm{e} \mathrm{4,5} \mathrm{t}$ de calcário/ha, o que elevou o pH de 4,6 a 5,7. A adiçăo de calcário resultou em aumentos nos teores de nitrogenio, fósfora, cálcio, porén resultou en reduçăo nos teores de potássio e magnésio e na quantidade total de magnésio nas plantas. o potássio teve efeito positivo na produção de materia seca, no teor de potássio e na quantidade extraida de nitrogenio, fósforo e potássio porem provocou redução nos teores de nitrogénio, fósforo, cálcio e magnésio no tecido 
Jas plantas, concordando com os resultados abtidos por JaNES \& FFEITAS (1970).

Sendo a alfafa uma cultura que requer concentraçớes relativamente elevadas da maioria dos elementos minerais, as niveis desses nutrientes no solo devem corresponder a um suprimento compativel com as necessidades dessa planta (LEACH \& CLEMENTS, 1985).

RANDO (1992), pesquisando o desenvolvimento da alfafa em niveis de $\mathrm{pH}$, de potássio e de enxofre no solo, constatou que o desenvolvimento da alfafa foi significativamente $(P>0,01)$ reduzido, em solo com elevada acidez, com reflexos intensos sobre o rendimento de materia seca, independente da adição de potássio e enxofre. Somente quando se eliminou a acidez foi possivel constatar os beneficios da adição de potássio e enxofre, os quais aumentaram a altura das plantas, o número de perfilhos, o diâmetro e o peso das ralzes, bem como a produçăo de matéria seca da parte aérea.

Os resultados observados en todos os trabalhos revisados, comprovam que existem diferenças marcantes entre culturas em relação à acidez do solo e resposta à calagem. Além disso, demostram a necessidade de se adotar metodos de recomendação de calagem, que sejam flexiveis a fim de permitir o cálculo da dose de calcario, de acordo com a exigéncia e a resposta da cultura à calagem.

Pode-se verificar, ainda, que são escassos os 
trabalhos utilizandc a metodo de saturação por bases para a cálculo da necessidade de calagen para alfafa.

\subsection{Potássio e a nutriçáa da alfafa}

Existem algung fatores que influenciam a disponibilidade de potássio para as plantas como: quantidade e tipos de minerais de argila, lixiviaçăo, estrutura do solo, conteúdo de água, temperatura, pH do solo e calagen. A prática da calagem e a consequente redução das toxicidades de aluminio e manganes, afeta a disponibilidade de potássio no 5010.

0 conhecimento dos efeitos de autros 1 ans na nutrição potássica importante, năo so para se maximizar a eficiencia do uso de potássio, mas também para se saber como os niveis de outros lons vão alterar as recomendaçర̋es feitas aos agricultores, sobre o emprego do adubo potássico.

YORK Jr. et al. (1954a) determinaram se a interação de cálcio - potássio na planta o devida a um antagonismo fisiológico entre os ians ou à interação cálcio potássio seria induzida no solo. Tiveram evidências de que a calagem influencia a concentração de potássio nas trocas do solo. Solos calcários possuem alta capacidade en fixar o potássio aplicado na forma não-trocável (ALLAWAY \& PIERRE, 1939; BLUME \& PURVIS, 1939; ATTOE, 1946; YORK Jr. \& ROGGERS, 1947). Os resultados demonstraram que aproximadamente $34 \%$ do 
potássio aplicado foi fixado até o maior nivel de calagen. Apontando que, quanto mais potássio adicionado ao complexo de troca, maior a porcentagem de saturação por bases, consequentemente mais potássio fixado quando um solo ácido recebe calcário.

VaRk Jr = et al- (1954b) estudaram a influência da calagem e do potássio na produção e na composição de cátions nas plantas. Concluiram que a aplicação de Kcl ao solo, sem o calcário, podera prejudicar a crescimento das plantas, pois ocasionaria um aumento no teor de manganes do tecido. A calagem não teve efeito significativo (P< $<, 05)$ na produção de matéria seca da alfafa na ausência de potássio, porén houve resposta significativa $(P<0,05)$ e positiva quando da aplicação de potássio. Encontrou-se maior teor de potássio na folha da alfafa quando não houve calagem. Os métodos de cultivos sucessivas dão boa estimativa de reserva de potássio do solo. No entanto, as quantidades estimadas variam com a especie utilizada. Isso decorre, da diferente capacidade das especies vegetais em reduzir a concentração de potássio da soluçăo e de sua capacidade de utilizar eficientemente o potassio, produzindo biomassa, sob concentraçôs extremamente baixas desse nutriente na solução do solo (SCHULTE \& COREY, 1965).

FRANCO \& DOBEREINER (1967) trabalhando com 5010 arenoso da série Ecologia, constataram efeito prejudicial do potássio na nodulação, em termos de número e 
tamanho de nódulos, ben como na fixaçăo de nitrogênio en feijão (Phaseolus vulgaris L.). Atribulram esse fato ao excesso de potássio, a que compete com o cálcio na absorção pelas plantas.

ANDREW \& ROBINS (1969) estudando o efeito do potássio no crescimento e na composição química de oito leguminosas de clima tropical e quatro de clima temperado, num sola com 0,04 meq $K^{+} / 100 \mathrm{~g}$ de solo, obtiveram resposta da adição de potássio para todas as especies, en termos de crescimento. Entretanto, năo constataram aumento na concentraçăo de potássio na planta para a menor dose de cloreto de potássio.

Num trabalho em casa de vegetação, que visava comparar as respostas da alfafa mais sete leguminosas tropicais, à aplicação de vários fertilizantes en solo sob cerrado do Estado de Săo Paulo, JoNEs et al. (1970) verificaram que, com a adubação completa a produçăo de materia seca de Hedicago sativa foi superior a dobro da leguminosa mais produtiva. A omissăo de potássio năo determinou alteração significativa $(P>0,05)$ da produçăo de materia seca de qualquer das leguminosas. A omissán de potássio na adubação, resultou em aumento no teor de nitrogenio das especies Desmodium pabulare, Clitoria ternatea e Neonotonia wighti $i$ e redução em Hedicago sativa.

JONES \& FREITAS (1970) conduziram um experimento em casa de vegetação estudando a produção de 
matéria seca e a assimilaçåo de nitrogenio por alfafa e quatro leguminosas tropicais num latossolo vermelho-amarelo ao qual aplicaram seis macro e cinco micronutrientes. Não se verificaram respostas en produção de materia seca das espécies ao nitrogénio ou potássio. A concentração de nitrogenio nas plantas variou segundo a adubação $e$ as espécies cultivadas. Con a adubação completa a produção de Medicago sativa fai superior ao dobro da produçăo da leguminosa tropical mais produtiva, concordando com a trabalho de JONES et al. (1970). Sem calagem o crescimento da Hedicago sativa foi nulo, tendo as plantas perecido antes da data da colheita, o que é mais un indicio de que é uma forrageira muito exigente quanto às condiçōes de acidez do so10.

A elevação do pH do solo pela calagen aumenta a capacidade de troca de cátions (CTC) dos solos que contém quantidades altas de minerais com cargas superficiais pH dependentes. A maior CTC efetiva aumenta a capacidade dos solos en reter potássio, removenda-o da salução do solo e reduzindo o potencial de perdas por lixiviaçăo. Altas doses de corretivos de acidez fornecen quantidades elevadas de cálcio as plantas, a que provavelmente estimulará o crescimento e a atividade das ralzes, porém muito cálcio pode impedir a absorção de potássio na superficie das ralzes. A calagen também pode resultar en retençăo de potássio en sitios de absorça seletivos, que anteriormente eram ocupados 
por cátions hidroxilados de alumínio.

Trabalhando com alfafa em seis solas do Rio Grande do Sul e verificando os efeitos no salo, KORNELIUS (1972) concluiu que a aplicação de cloreto de potássio causou a redução no pH dos solos, aumentou o manganes trocável e incrementou a absorção de manganes pela alfafa, nos niveis mais baixos de calcário. Esses resultados concordaram com os de YaRK Jr. et al. (1954b) e RANDO (1992).

LOVADINI et al-(1977) estudaram o efeito de niveis de calagem, fósforo e potássio na produção de materia seca de soja-perene (Neonotonia wightii) em solos de cerrado. Houve resposta significativa $(P<0,05)$ na produçå de matéria seca apenas ao calcario e ao superfosfato simples. A aplicação de potássio năo apresentou efeito significativo (P $>0,05$ ) na produção de matéria seca, confirmando dados obtidos por ANDREWS \& ROEINS (1969).

GOEDERT et al. (1975) trabalhando com duas classes de solos (Oxissolos e Ultissolos) do Sul do Brasil, conclufram que a calagem provocou o decréscimo da quantidade de potássio na soluçă, embora tenha sido mantido aproximadamente o mesmo nivel de potássio trocável e a capacidade tampåo do potássio aumentou. Concluiram que, embora a calagem diminuisse a suscetibilidade do potássio à lixiviação, ela também podia reduzir o potássio em solução a niveis que causavam deficiencia nas plantas.

$$
\text { ARNON (1975) relatou alguns aspectos }
$$


relacionados à nutrição do milho com potássio, cálcio e magnésio. Aplicaçชes elevadas de potássio puderam levar à deficiéncia de magnésio, sendo o antagonismo entre magnésio e potássio maior do que entre cálcio e potássio. a possivel antagonismo entre potássio e cálcio apareceu somente em niveis altos de potássio. Em baixos niveis de potássio, aumentando-se o suprimento de potássio, houve tendencia de ocorrer um aumento na absorção de calcio, a que pode ser creditado a melhoria na fisiologia da planta em funçăo da melhor nutrição potássica.

MAGDORFF \& BARTLETT (1980) estudando o efeito da calagen sobre a disponibilidade de potássio em solos ácidos, obtiveram un decrescimo da disponibilidade do potássio na solução, com o aumento das doses de calcário, o que concorda com GOEDERT et al. (1975).

Em vários experimentos, onde a proporçăo de calcário foi variada, a absorçăo de potássio do solo pode ser afetada pela calagem. Ȧ medida que a proporção de calcário diminuiu, a produção também decresceu e, portanto, mais potássio não aproveitado permaneceu no sistema do solo. Este potássio residual complica a interpretaçăo da distribuiçăo do potássio no solo, a não ser que as observaçชes se limitem à uma amplitude de doses de calcário que tenham pouco efeito sobre a produção ou absorf̧ão de potássio.

SIlva et al. (1984) relacionaram a resposta do algodoeiro (Gossypium hirsutum) adubaçăo potássica com a 
aplicação de caluário e com a relação (Ca + Mg)/K. A produção do algodoeiro aumentou de forma linear com a calagem, quando em presença de potássio, em especial na dose de $100 \mathrm{~kg} \mathrm{KaD/ha.} \mathrm{Ja} \mathrm{na} \mathrm{auséncia} \mathrm{de} \mathrm{adubação,} \mathrm{os} \mathrm{acrescimos}$ foram menores e de natureza quadratica e não significativos (P $>0,05)$. Puderam os autores concluir que a reação das plantas ao cloreto de potássio foi mais acentuada na presença de calcário.

DEFELIPO \& BRAGA (1983) estudando dez Latossolos de Minas Gerais, constataram efeito significativo (F $<0,01)$ da calagem na absorção e retenção de potássio pelo 5olo. Esse aumento da adsorça de potássio devido a calagem, segundo os autores, pode ser justificado pela facilidade do potássio en substituir o cálcio no complexo de troca $e$ a aumento da carga negativa dos solos, devido aos óxidos de ferro e aluminio em função da elevação do pH.

Segundo MIELNICZUK (1977) a calagem deveria reduzir a potencial de perda de potássio por lixiviaçăo. Ela aumenta a capacidade de troca catiónica, devido ao aumento do pH. Desta forma fornece mais sitios de troca para a retença de potássio. Alén disso, a calagem precipita o aluminio trocável e, por isso, facilita a retenção, porque o patássio pode competir melhor com as lons cálcio, que permanecem no complexo de troca que com o aluminio que lá estava originalmente. Mostrou o autor, que a capacidade-tampå de potássio de um latossolo vermelho-escuro aumentou muito com a 
calagem a $\mathrm{pH}, 6,0$.

0 experimento, executado en camara de crescimento, investigando a influencia de trés niveis de potássio (controle, médio $e$ alto) e duas fontes (KCl e K2504), na fatossintese, na concentração de carboidrato e na fixação de nitrogenio da alfafa conduzido por Collins a STANLEY (1981) permitiu verificar a influencia positiva do potássio e do enxofre no crescimento da alfafa. Plantas fertilizadas com potássio como K2S0. tiveram maior número de nódulos, comparada com as do tratamento do fertilizante Kc1. Todos os tratamentos influenciaram a concentração de nitrogenio, tanto na parte aerea como nas raizes. A aplicação de potássio no solo aumentou a concentração de potássio na parte aerea e nas ralzes en relaçăo ao tratamento testemunha. Entretanto, o nival mais alto de potásio aplicado, resultou em apenas um moderado aumento no conteúdo de potásio na planta, comparando com a nivel médio de potássio aplicado.

E frequente $a$ consumo de luxo de potássio, sendo este nutriente extraido em grandes quantidades pelas culturas e especialmente pelas leguminosas. 0 potassio apresenta elevada importáncia para as leguminosas en termos de aumento de produção, qualidade e longevidade do estande. Pode-se encontrar na literatura uma amplitude de variacão dos niveis críticos de potássio nos solos brasileiros de 0,13 a 0,20 meq $K^{+} / 100 \mathrm{~g}$. sendo dependente da planta $e$ do solo: 
segundo RITCHEY (1982).

BülL (1986) estudando a influência da relação $K /(\mathrm{Ca}+\mathrm{Mg})$ do solo na produçăo de matéria seca e na absorçă de potássio por graminea e leguminosa forrageira, pode concluir que a leguminosa apresentou uma maior absorça de potássio e de cálcio + magnésio que a gramínea, que o aumento de absorção de potássio foi função da elevação nas relaçơs $K /(\mathrm{Ca}+\mathrm{Mg})$ no solo, e que promoveram, decréscimos proporcionais na absorção de cálcio + magnésio pelas espécies testadas.

Com a objetivo de determinar a influencia da calagen sobre as perdas por lixiviação de potássio, cálcio e magnesio, BRAUNER \& GARCEZ (1982) conduziram um experimento em casa de vegetação usando trés tipos de solo, classificados como Planossolo, podzólico vermelho-amarelo e Brunizem do Rio Grande do Sul. Constataram que o pH do solo e as concentraçôes de potássio e cálcio na planta aumentaram em resposta às quantidades de CaCOs adicionadas ao solo. Com relação ao magnésio, não houve tendência bem definida em função dos niveis de CaCos. As variaçôes de pHe de calcio eram previsiveis, enquanto os de potássio foram inesperados, segundo os autores, e provavelmente devidas a uma liberação de formas fixadas. Os niveis de Cacos utilizados influenciaram as perdas de potássio e cálcio nos trés solos utilizados, mas não as de magnésio. Para os tres elementos analisados independente da influéncia de CaCOs, as perdas por 
lixiviaçăo for.um influenciadas, também, pela natureza do solo. A tendencia de aumento por lixiviação, em resposta às doses de CaCDэ adicionadas poderia, aparentemente, estar associada ao aumento do potássio disponivel. No entanto, isso não encontra apoio en RAIJ \& CAMARGo (1974) que trabalharam com dez amostras de solo do Estado de São Paulo e evidenciaram que o potássio 1 ixiviado era mais dependente dos teores de cálcio e magnésio trocáveis do que as teores de potássio trocável daqueles solos. Esses autores destacaram que os aumentos no cálcio e magnésio diminuíram as perdas de potássio por lixiviaçăo e ressaltaram que as perdas de magnésio por lixiviaçăo foram maiores do que aquelas de potássio, discordando de BRAUNER \& GARCEZ (1982), onde as perdas de magnésio, quando comparadas com as de potássio, foram inferiores.

BARBARICK (1985) conduziu um experimento no campo e em casa de vegetação avaliando por quatro anos uma adubação potássica, num solo com adequado nivel de potássio. o experimento conduzido no campo constou de trés niveis de potássio (0, 375 e $750 \mathrm{~kg}$ potássio/ha) aplicados na forma de K2SO4. 0 estudo na casa de vegetação foi estabelecido para determinar o efeito de quatro fertilizantes (KC1, K2SO4, MgCl2 e MgSO4) aplicados em quatro niveis $(0,189,376$ e 752 kg Ke Mg/ha) sobre a produção e composição catiónica da alfafa. Q autor concluiu que, aparentemente, potássio e magnésio, competem pelo mesmo sitio de absorção na planta 
mesmo que os niveis no solo estejan baixos. A aplicação de potássio ou magnesio resultou numa resposta positiva na produçăo de materia seca. 0 magnésio propiciou resultado similar ao potássio no experimento da casa de vegetaçao. A alfafa respondeu à aplicação de potássio, mesmo num solo com altos niveis de potássio, provavelmente, segundo o autor, por causa da supressão de sódio, certamente restabelecendo o potássio.

YAMADA (1987) concluiu que os solos brasileiros, dado ao alto grau de intemperismo, apresentam uma pequena reserva de potássio. As possiveis exceçôes podem ser creditadas aos solos em que a fração argila é dominada por montmorilonita e mica. Os solas bem supridos de potássio săo aqueles bem tamponados, contendo boa concentraçăo de potássio na solução ao longo do ciclo da cultura e com boa capacidade de retenção de água.

RICCI et al. (1989) estudaram as fraç8ses granulometricas do solo como reserva de potásio para as plantas, objetivando verificar o fornecimento de potássio por essas fraçôes. Foram realizados cinco cultivos sucessivos com sorgo, em casa de vegetaçăo, em amastras de cinco solos de diferentes texturas e regiós do Estado de Minas Gerais. Pelas análises dos teores de potássio trocável, potássio não trocável e potássio total, verificou-se a distribuiçăo dessas formas nas diferentes fraçర̃es granulometricas dos solos $e$ a resistencia quanto a alteraçåo desses teores durante os 
cultivos. Os teores de potássio total dos solos foran. muito superiores aos das demais formas de potássio. Entretanto, a forma não trocável, que indica reserva de potássio a médio prazo, não fai superior a trocável. Concluíram os autores, que somente a avaliação conjunta de todas as formas de potássio poderá predizer a capacidade de suprimento de potássio dos solos a curto, medio e longo prazo.

Experimentos caracterizando o suprimento de potássio e o potássio não trocável en doze solos calcários, cultivados com alfafa em casa de vegetaçăo, por 584 dias (dezesseis cortes) HAVLIN \& WESTFALL (1985) concluiram que solos argilosos possuem suprimento adequado de potássio disponivel à planta, enquanto solos de textura arenosa năo possuem. Depois de dezesseis cortes, a nivel de potássio não trocável nos solos de textura argilosa, média e arenosa decresceu em 44,33 e $58 \%$, respectivamente.

Foram estudados os efeitos das aplicaçơes de magnesita e cloreto de potássio en niveis de calcário sobre o crescimento de plantas de algadoeiro, en dois latossolos de Minas Gerais (PENA, 1991), com a finalidade de avaliar a efeito desses tratamentos sobre o pH e os teores de cálcio, magnésio e potássio trocáveis do solo e a concentraçao desses nutrientes na parte aérea das plantas. Ocorreram diferenças significativas ( $P<0,05$ ) entre niveis de calagem $e$ entre solos para todas as variáveis, exceto os teores de potássio trocável no solo. As aplicaçßes de magnesita e cloreto de 
potássio influfram na produção de matéria seca das plantas. Verificou ainda, o autor, uma interação positiva da produção de materia seca da parte aerea com o aumento das doses de corretivo. Doses elevadas de cloreto de potássio e magnesita tiveram efeito depressivo sobre o conteúdo de cálcio na parte aérea das plantas, sendo menor esse efeito com o aumerto das doses de calcário. Os níveis criticos de cálcio, magnésio e potássio no solo foram influenciadas pelas doses de calcário e pelas caracteristicas do solo, tal como a teor de argila.

KELLING \& ERICKSON (1984) verificaram que a sobrevivencia da população de plantas de alfafa foi significativamente $(P<0,05)$ potencializada pela adubaçă potássica em todos os solos que apresentaram conteúdos inferiores a $170 \mathrm{~kg} \mathrm{K/ha.} \mathrm{Concordando} \mathrm{com} \mathrm{os} \mathrm{resultados} \mathrm{de}$ nove anos de pesquisa, mostraram que a manutenção de estande produtivo e de maior longevidade só foi alcançado com aplicaçช̃es anuais de $190 \mathrm{~kg} \mathrm{~K} / \mathrm{ha}$ (MARKus \& BATTLE, 1965).

RANDD (1992) observou que a aplicação de cloreto de potássio incrementou significativamente ( $P<0,05$ ) o teor de manganos na matéria seca de alfafa na parte área, concordando com YaRK Jr. (1954b). A aplicaçăo de potássio diminuiu significativamente $(P<0,01)$ a concentraçăo de cálcio e magnésio das plantas nos dois niveis de pH (em água) testados $(5,4$ e 6,8$)$.

CARMELlo (1989) analisando o efeito da saturação por bases em relação ao potássio, câlcio e magnesio 
do solo na nutricão potássica do milho (Zea mays L.), concluiu que a extração de potássio pelas plantas diminuiu com o aumento na relação Ca/Mg a a produção de matéria seca foi afetada de forma positiva pelo aumento na porcentagen de saturação por bases.

$$
\text { WASSERMANN \& BERG (1990) conduziram um }
$$

experimento em vasos e outro no campo a fim de comparar as respostas de alfafa e Onobrychis viciafolia scop., as aplicaçóes de fóstoro, potássio e calcário. Os resultados do experimento en vasos sugeriram resposta as calagem de onobrychis quando comparada com a de alfafa em termos de produção de matéria seca da parte aerea. Por outro lado, os requerimentos de fósforo e potássio pela alfafa foram considerados superiores aos de onobrycis. Quanto ao potássio, apenas a alfafa respondeu significativamente $(P<$ $0,01)$, o que foi confirmado pelo experimento no campo. Acrescentaram ainda os autores, haver uma tendencia de reduzir o conteúdo de protelna bruta nas folhas com a aplicação de potássio. 
3. Material e metodos

0 experimento foi conduzido em vasos, em casa de vegetação no Departamento de Química, da Escola Superior de Agricultura "Luiz de Queiroz"/USF, em Piracicaba, Estado de 5å Paulo, no periodo de junho a qutubro de 1991.

\subsection{Forrageira}

Foi estudada a leguminosa forrageira alfafa (Hedicago sativa L.), testando-se os cultivares crioula, Moapa, Florida 77 e CUF 101.

\subsection{Sola}

0 solo utilizado no experimento pertence ao grande grupo latossolo vermelho-amarelo (LVA) fase argilosa. Foi coletado a uma profundidade de 0 a 30 centimetros, foi seco a sombra, homogeneizado e passado em peneira com malha de 3 millmetros.

Do solo seco e peneirado foram retiradas amostras para análises químicas, que revelarams materia 
orgânica $=3,59 \% ;$ pH (em Cacl2 0,01 Molar $)=4,68 ;$ fósforo resina $=3,0 \mu g / m 1 ;$ hidrogénio + aluminio $=2,70 ;$ cálcio $=$ 1,42 ; magnésio $=0,72 ;$ potássio $=0,09 ;$ sama de bases (S) = 2,23 e CTC $=4,93$ (meq/100 $\mathrm{cm}^{3}$ T.F.5.A.). A porcentagem de saturação por bases (V\%) nessas amostras estava em $45 \%$.

\subsection{Delineamento experimental}

Empregou-se o delineamento experimental de blocos ao acaso, num esquema fatorial $4 \times 3 \times 4$, com quatro niveis de calcário; trés niveis de adubaçăo potássica e quatro cultivares, envolvendo 48 tratanentos com quatro repetiços, totalizando 192 vasos.

\subsection{Calagen e incubaçăo da terra}

Foram empregados vasos de polietileno com capacidade para quatro quilogramas de terra seca.

Calculou-se a necessidade de calagem de acordo com a criterio da porcentagem de saturaçăo por bases preconizado por RAIJ et al - (1985).

A aplicação do corretiva foi efetuada em 30 de abril de 1991, seguindo-se os cálculos para elevar a saturação por bases do solo (V\%) a: 45\% (sem aplicaçăo de corretivol: 60\% correspondendo a uma aplicaçăo de $950 \mathrm{~kg}$ de corretivo/ha; $75 \%$ correspondendo a uma aplicaçăo de $1.900 \mathrm{~kg}$ 
de corretivo/ha; $90 \%$ corresponciendo a uma aplicação de 2.850 kg de corretivo/ha.

Utilizaram-se os reagentes anallticos puros CaO e MgO na proporção 2:1, finamente mol dos e peneirados em malha 50, correspondendo a uma calcário dolomítico contendo 25,7\% CaO e 12,8\% de Mgo (portanto com un equivalente em CacOg e PRNT de $77,9 \%$ ).

Após a calagem, o solo recebeu agua destilada até a capacidade de campo, já previamente determinada, tendo sido os vasos cobertos com plástico. Os vasos foram pesados semanalmente, adicionando agua para completar novamente a capacidade de campo, permanecendo incubados por 49 dias, até o preparo para o plantio.

\subsection{Plantio e conduçáo do experimento}

Findo a periodo de incubação efetuou-se o destorroamento nos vasos.

A semeadura de cada cultivar foi conduzida no dia 18 de junho de 1991. As sementes (20 por vasa), foram colocadas en sulcos com $0,5 \mathrm{~cm}$ de profundidade e a $2 \mathrm{~cm}$ da borda do vaso. Colocaram-se em cada vaso, $25 \mathrm{ml}$ de suspensão de Rhizobium aliloti em água destilada.

Após a germinaçå das sementes, foram efetuados sucessivos desbastes, até a permanencia de cinco plantas por vasa. 
Os seguintes nutrientes foram aplicados em todos os vasos, na forma de solução diluida, momentos após o plantio $e$ sob a forma dos reagentes analiticos com as respectivas quantidades: $\mathrm{NaH}_{2} \mathrm{PO}_{4} . \mathrm{H}_{2} \mathrm{O}$ (466,5 $\left.\mathrm{mg} / \mathrm{vasa}\right)$ correspondendo a $65,5 \mathrm{~kg}$ P/ha; NazSO4 (213,0 $\mathrm{mg} / \mathrm{vaso})$ correspondendo a $30 \mathrm{kgg} / \mathrm{ha}$ HaBOa $(18,04 \mathrm{mg} / \mathrm{vasa})$ equivalente a $2,0 \mathrm{~kg} \mathrm{B/ha;} \mathrm{CuClz.2HzO}(8,55 \mathrm{mg} / \mathrm{vaso})$ correspondendo a 2 $\mathrm{kg} \mathrm{Cu} / \mathrm{ha}$; $\left(\mathrm{NH}_{4}\right)$ ollorO24.H2O $(0,74 \mathrm{mg} / \mathrm{Vaso})$ correspondendo a $250 \mathrm{~g}$ de Mo/ha $\operatorname{ZnClz}(6,70 \mathrm{mg} / \mathrm{vasa})$ equivalente a $2 \mathrm{~kg}$ Zn/ha.

A adubação potássica foi efetuada trés dias apos o plantio, com a aplicaçăo de uma solução preparada a partir do reagente analitico cloreto de potássio. Os niveis testados foram: sem adubação potássica; $100 \mathrm{~kg} \mathrm{~K} / \mathrm{ha}(477,5 \mathrm{mg}$

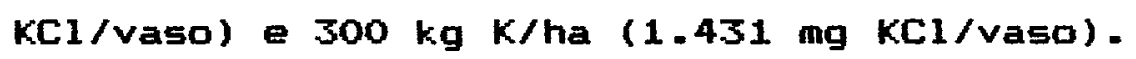

Após o plantio e durante todo a periodo de cultivo da leguminosa, os vasos foram irrigados diariamente com água destilada, para manter o solo próximo da capacidade de campo. Semanalmente eram realizadas pesagens individuais dos vasos e ajuste da umidade da terra em cada vaso.

A forrageira foi submetida a dois cortes. No inicio de florescimento, em 28 de agosto de 1991 (70 dias após o plantio), procedeu-se ao primeiro corte em todos os vasos. O segundo corte foi realizado aos 104, 106, 109 e 111 dias apos a plantio, respectivamente para o primeiro, segundo, terceiro e quarto blocos experimentais, a fim de 
viabiliza; a colheita das raizes.

Após o primeiro corte, o KCl foi reaplicado nos vasas ( $\mathrm{i}$ veis $K_{1} \mathrm{e} K_{2}$ ) que receberam potássio no inicio do experimenta, de mado a repor esse nutriente, farnecendo 50 $\mathrm{kg} \mathrm{K} / \mathrm{ha}(23 \mathrm{~B}, 75 \mathrm{mg} \mathrm{KCl} / \mathrm{vasa})$.

Imediatamente apos a segundo corte, as raizes foram separadas do solo atraves de jatos de água corrente e posteriormente lavadas com água destilada.

Todo material vegetal colhido (parte aerea e raízes) sofreu secagem a $65^{\circ} \mathrm{C}$ em estufa de circulaçăo forçada de ar até peso constante. Posteriormente, a parte aérea (primeiro e segundo corte) e as raizes foram pesadas separadamente, e moldas em moinho tipo Wiley.

\subsection{Análises químicas das plantas}

Em todo material da parte aérea da leguminosa procederam-se as determinaçöes de nitrogenio, fósoro, potássio, cálcio, magnésio, enxofre, boro, cobre, ferro, manganes e zinco. Nas ralzes moldas determinou-se o nitrogénio.

Para todas essas determinaçßes foram seguidos os procedimentos descritos por SARRUGE HAAG (1974).

a nitrogênio foi determinado pelo mostodo semi-micro Kjeldahl, con oxidação da matéria organica por ácido sulfúrico, en presença de agentes catalizadores $e$ sais 
para elevar a temperatura de ebulição do ácido.

Na determinação do boro empregou-se o método da azometina, com leitura no colorimetro fotoeletrico Klett-Summerson.

A extraçåo nitrico-perclórica foi utilizada como ponto de partida para as demais determinaçбes.

0 fósforo foi determinado pelo método do vanadato-molibdato de amónio, com leituras em colorimetro fotoeletrico Klett-Summerson.

Para a determinação do cálcio fez-se uma diluição inicial do extrato com oxido de lantânio e procedeu-se a leitura em espectrofotómetro de absorção atómica Perkin Elmer 360.

0 potássio foi determinado en extrato nitrico-perclórico diluldo en água deionizada, sendo a leitura feita em fotómetro de chama micronal B262.

Empregou-se o metodo indireto para a determinação do enxofre, atraves do emprego de solução com excesso de bário e a leitura deste elemento no sobrenadante.

As demais leituras de magnésio, cobre, ferro, manganes e zinco, foran efetuadas em espectrofotómetro de absorção atómica Perkin Elmer 360. 


\subsection{Amostragens do $\mathbf{9 0 1 0}$}

Dois dias antes do plantio (em 16 de junho de 1991), efetuou-se uma amostragem dos solas, retirando-se, com uma espatula de aço inoxidável, pequenas porçóes do solo dos vasos, segundo os niveis de calagem estudados. Assim, foram coletadas duas amostras dentro de cada nivel de calagem e de cada bloco experimental, de tal forma a serem recolhidas 32 amostras compostas.

Após a corte e remoção da parte aerea da planta no segundo corte $e$ antes da lavagem das raizes, realizou-se uma nova amostragem de terra. As amostras foram retiradas de cada vaso, com o auxilio de espatula de aço inoxidável, alcançando o fundo do vaso e totalizando 192 amostras de terra.

\subsection{Analises quimicas do \$olo}

Em todas as amostras coletadas foram determinados fósforo, matéria orgánica, pH, potássio, calcio, magnésio, H+Al, soma de bases trocaveis, capacidade de troca de cations e porcentagem de saturaçao por bases, conforme metodologia descrita por RAIJ et al. (1987).

0 pH fai obitido em suspensão do salo com uma solução de cloreto de cálcio $0,01 \mathrm{M}$.

A determinação da acidez potencial foi através 
da solução tampão SMP, com a leitura do pH transformada em meq $H+A 1 / 100 \mathrm{~cm}^{3}$, atraves da equação in $(H+A 1)=7,76-1,053$ pH SMP.

A determinaçao da materia orgânica foi realizada através da oxidaçăo por dicromato de sódio em ácido sulfúrico à frio e leitura em colorimetro.

Determinaram-se fósforo, cálcio, magnésio e potássio por extraçăo, através da resina trocadora de $10 n s$, separação da resina do solo e extração dos elementos da resina com solução ácida de cloreto de amónio.

A leitura de fósforo fai atraves da colorimetria utilizando a solução de molibdato com gelatina e ácido ascóbico; a de potássio foi atraves da fotometria de chama com o extrato diluido em água.

As leituras de calcio e magnésio foram realizadas en espectrofotómetro de absorção atómica, utilizando extrato mais solução de oxido de lantanio a $0,1 \%$ (1 ml do extrato + $10 \mathrm{ml}$ de solução contendo lantanio).

A soma de bases trocáveis, a capacidade de troca de cations e a porcentagem de saturação por bases foram obtidas a partir dos resultados das determinaçชes descritas individualmente. 


\title{
3.9. Análises estatisticas
}

\begin{abstract}
A analise estatistica dos resultados baseou-se em GOMES (1970). Efetuou-se análise de variáncia dos resultados referente a produção de matéria seca da parte aérea (em cada um dos dois cortes) e dos referentes a produção de matéria seca das ral zes, assim como da análise do s010.

o teste F foi usado para se determinar as significâncias dos tratamentas com desdobramento para as regressöes linear e quadrática (para calagem e potássio). Usou-se o teste de TUKEY para comparação das medias de cultivares.
\end{abstract}




\title{
4. RESUltados E DigCussán
}

4.1. Efeitos do calcário e do potassio no solo

\begin{abstract}
Ds resultados das análises químicas das amostras de solo coletadas nos vasos dois dias antes do plantio da leguminosa forrageira gão apresentados na Tabela 1.
\end{abstract}

Tabela 1. Resultados das análises quimicas do solo, em amostras retiradas 42 dias depois da calagem e antes do plantio. Médias de oito repetiçøes.

\begin{tabular}{|c|c|c|c|c|c|c|c|c|c|c|}
\hline $\begin{array}{l}\text { Calcário } \\
\text { (kg/ha) }\end{array}$ & $\begin{array}{c}P \\
\mu g / m \mathbf{m}\end{array}$ & $\begin{array}{c}\text { M.O. } \\
\%\end{array}$ & $\begin{array}{c}\mathrm{pH} \\
\mathrm{CaCl}_{2}\end{array}$ & $k$ & Ca & $\mathrm{Mg}$ & $\begin{array}{r}H+\Delta l \\
-\operatorname{meq} 1\end{array}$ & $\begin{array}{c}5 \\
00 \mathrm{~cm}-\end{array}$ & $\begin{array}{c}T \\
----\end{array}$ & $\begin{array}{l}v \\
\%\end{array}$ \\
\hline 0 & 5,99 & 5,06 & 4,92 & 0,09 & 2.25 & 0,90 & 3,43 & 3,23 & 6,66 & 48,5 \\
\hline 950 & 4,43 & 4,38 & 5,03 & 0,08 & 2,58 & 1,13 & 2,89 & $\mathbf{3 , 8 1}$ & 6,67 & 56,6 \\
\hline 1900 & 4,73 & 4,36 & 5,26 & 0,09 & 2,73 & 1,17 & 2,53 & 4,01 & 6,54 & 61,1 \\
\hline 2850 & 5,15 & 4,54 & 5,61 & 0,08 & 3,54 & 1,58 & 2,22 & 5,20 & 7,40 & 70,0 \\
\hline$F$ & * & * & $\star \star$ & ns & $\star \star$ & $\star \star$ & $\star \star$ & $\star \star$ & $\star \star$ & $\star *$ \\
\hline Reg. lin. & ns & * & $\star \star$ & ns & $\star \star$ & $\star \star$ & $\star \star$ & $\star \star$ & $\star$ & $\star \star$ \\
\hline Reg. quad. & * & * & $\star \star$ & ns & * & * & * & * & * & ns \\
\hline C.V. $(\% / 0)$ & 16,3 & 7,6 & 1,0 & 11,0 & 8,6 & 10,0 & 4,6 & 7,8 & 5,1 & 3,5 \\
\hline
\end{tabular}

$\star_{*}$ * e ns = significativo aos niveis de $5 \%$ e $1 \%$ e não significativo, respectivamente. 
A aplicação de calcário ao solo resultou em elevaçôes do $\mathrm{pH}$, dos teores de cálcio e magnesio trocáveis, da soma de bases (S), da capacidade de traca de cátions (T), bem como da porcentagem de saturação por bases (V) do solo (Tabela 1). Variaçôes desse tipo são amplamente mencionadas na literatura, como por CAMARGO \& RAIJ (1976) e MALAVOLTA (1976).

A necessidade de calagem (NC) pode ser definida como a quantidade de corretivo a ser aplicada ao solo para neutralizar a sua acidez, elevando-se o pH e a porcentagem de saturação por bases até um nível desejável.

Através dos resultados obtidos, constata-se que a porcentagem de saturação por bases do solo atingiu um valor máximo de 70\%, quando o objetivo era alcançar $90 \%$.

Segundo ALCARDE (1983), a reatividade dos corretivos no solo, isto $f$, a velocidade com que agem no solo e neutralizam a acidez, depende, alem do tamanho das suas particulas, também da natureza química dos seus constituintes neutralizantes.

Existe uma correlação positiva entre pH e porcentagem de saturação por bases (V) do solo, conforme demonstrado, entre outros, por CATANI \& GALLO (1955). Portanto: elevar o nivel de saturaçăo por bases corresponde a elevar o $\mathrm{pH}$ e diminuir o H + Al do solo.

KORNELIUS (1972) concluiu que $0 \mathrm{pH}$ foi decisivo para a produção de alfafa, atingindo produçós 
máximas de materia seca entre pH 6,3 e 7,5; ressaltando que elevação excessiva do pH causa deficiencia de micronutrientes.

As doses de calcário aplicadas ao solo resultaram en efeitos quadraticos para os teores de materia orgânica, cálcio, magnésio, hidrogênio + aluminio, para soma de bases (S) : capacidade de troca catiónica (T), e para pH e teor de fóforo. Para a porcentagem de saturaçăo por bases a resposta as doses de calcário foi linear (Figura 1 ). Concordando com JOHN et al. (1972) que verificaram incrementos significativos $(P<0,05)$ na porcentagen de saturação por bases nos solos que receberam calcário. As equaçoses de regressão e seus respectivos coeficientes de determinação encontram-se na Tabela 2 . 
Tabela 2. Equaçớs de regressão obtidas entre as variáveis estudadas no solo (antes do plantio), para os niveis de calcario testados $10 ; 950 ; 1900$ e 2850 kg/ha) e seus respectivos coeficientes de determinação $\left(R^{2}\right)$.

\begin{tabular}{|c|c|c|c|}
\hline Variável estudada & Equa & ação de regressão & $R^{2}$ \\
\hline Tear de fósfaro & $\mathbf{Y}=$ & $\begin{array}{l}5,900625-0,001801974 x+ \\
0,000000055 x^{2}\end{array}$ & 0,90 \\
\hline $\begin{array}{l}\text { Teor de matéria } \\
\text { organica (\%) }\end{array}$ & $Y=$ & $\begin{array}{l}5,035751-0,0008432903 x+ \\
0,00000024 x^{2}\end{array}$ & 0,97 \\
\hline $\mathrm{pH}(\mathrm{CaCl})$ & $Y=$ & $\begin{array}{l}4,924689+0,0000391439 x+ \\
0,000000709 x^{2}\end{array}$ & 0,99 \\
\hline Teor de cálcio & $Y=$ & $\begin{array}{l}2,285875+0,00005092 x+ \\
0,000000130 x^{2}\end{array}$ & 0,97 \\
\hline Teor de magnésio & $Y=$ & $\begin{array}{l}0,9251875+0,000082434 x+ \\
0,00000048 x^{2}\end{array}$ & 0,94 \\
\hline 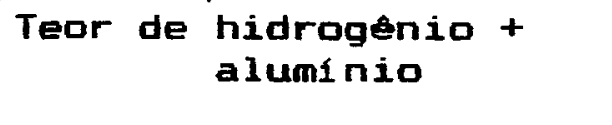 & $Y=$ & $\begin{array}{l}3,422938-0,0005983 x+ \\
0,00000067 x^{2}\end{array}$ & 0,99 \\
\hline Soma de bases (5) & $Y=$ & $\begin{array}{l}3,29375+0,000171052 x+ \\
0,0000017 x^{2}\end{array}$ & 0,96 \\
\hline $\begin{array}{l}\text { Capacidade de troca } \\
\text { catiónica (T) }\end{array}$ & $Y=$ & $\begin{array}{l}6,72-0,00045263 x+ \\
0,00000024 x^{2}\end{array}$ & 0,86 \\
\hline Saturaçăo por bases (V\%) & $Y=$ & $48,69625+0,0072724 x$ & 0,99 \\
\hline
\end{tabular}




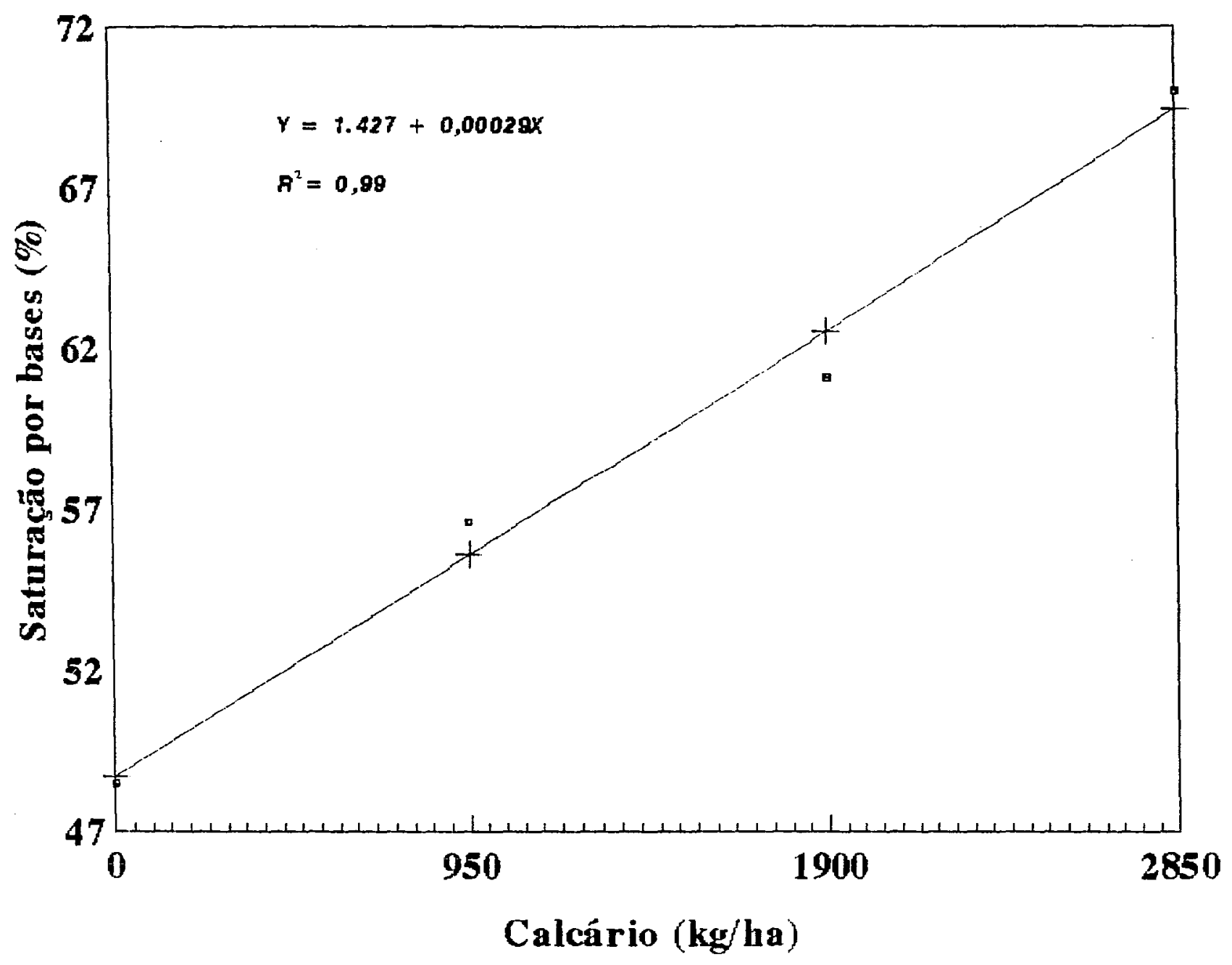

Figura 1 - Porcentagen de saturaça por bases no solo, antes do plantio, em funçăo dos niveis de calcário aplicados. 
A Tabela 3 consta dos resultados das análises químicas das amostras de solo retiradas no dia da colneita final das leguminosas.

Tabela 3. Resultados das análises quimicas do solo, em amostras tomadas no dia da colneita final da leguminosa forrageira cultivada. Significancia do teste $F$ e para os componentes linear e quadrático. Médias de quatro repetiçชes.

\begin{tabular}{|c|c|c|c|c|c|c|c|c|c|c|}
\hline $\begin{array}{l}\text { Efeitos } \\
\text { principais }\end{array}$ & $\begin{array}{c}P \\
\mu g / m !\end{array}$ & $\begin{array}{c}\text { M.O. } \\
\%\end{array}$ & $\begin{array}{c}\mathrm{PH} \\
\mathrm{CaCl}_{2}\end{array}$ & $K$ & $\mathrm{Ca}$ & $\mathrm{Mg}$ & $\begin{array}{c}H+A l \\
\text { meq/1 }\end{array}$ & $00 \mathrm{~cm}=$ & $T$ & $\begin{array}{l}V \\
\%\end{array}$ \\
\hline & \multicolumn{10}{|c|}{ CULTIVAR } \\
\hline rioula & $20,71 \mathrm{~A}$ & 3,94AB & $4,90 A$ & $0,17 A$ & $1,84 A$ & $0,83 A$ & $5,04 A$ & $2,84 A$ & $7, \mathrm{BBA}$ & $37,22 \mathrm{~A}$ \\
\hline oapa & $23,47 A$ & $3,94 \mathrm{~B}$ & $4,81 \mathrm{AB}$ & $0,17 A$ & $1,85 A$ & $0,83 A$ & $5,15 \AA$ & $2,83 A$ & 7,984 & $36,33 A$ \\
\hline orida 77 & $19,68 \mathrm{~A}$ & 3,92 B & $4,70 \mathrm{BC}$ & $0,16 A$ & $1,81 A$ & $0,81 A$ & $4,98 A$ & $2,80 A$ & $7,77 \mathrm{~A}$ & 36,671 \\
\hline UF 101 & $22,32 A$ & $4,14 A$ & $4,66 C$ & $0,16 \AA$ & $1,87 A$ & $0,83 A$ & $5,11 A$ & $2,87 A$ & $7,98 \mathrm{~A}$ & 36,714 \\
\hline & ns & $\star \star$ & $\star \star$ & ns & ns & ns & ns & ns & & ns \\
\hline
\end{tabular}

Calcário

( $\mathrm{kg} / \mathrm{ha})$

\begin{tabular}{|c|c|c|c|c|c|c|c|c|c|c|}
\hline 0 & 20,23 & 3,89 & 4,54 & 0,18 & 1,43 & 0,60 & 5,66 & 2,22 & 7,98 & 28,66 \\
\hline 950 & 23,17 & 3,99 & 4,68 & 0,17 & 1,71 & 0,76 & 5,40 & 2,64 & 8,04 & 33,70 \\
\hline 1900 & 20,98 & 4,03 & 4,85 & 0,16 & 1,95 & 0,89 & 4,85 & 3,00 & 7,86 & 38,94 \\
\hline 2850 & 21,74 & 4,04 & 5,00 & 0,15 & 2,28 & 1,05 & 4,27 & 3,47 & 7,74 & 45,65 \\
\hline $\mathrm{F}$ & ns & ns & $\star \star$ & * & ** & *夫 & $\star \star$ & 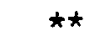 & $\star \star$ & $\star \star$ \\
\hline tin. & ns & ns & $\star \star$ & $\star \star$ & $\star \star$ & $\star \star \star$ & $\star \star$ & $\star \star$ & $\star \star$ & $\star \star$ \\
\hline g. quad. & ns & ns & ns & ns & ns & ns & ns & ns & n5 & ns \\
\hline
\end{tabular}

$\kappa$

(kgha)

\begin{tabular}{lcccccccccc}
$\quad 0$ & 20,75 & 3,93 & 4,80 & 0,05 & 1,89 & 0,84 & 4,91 & 2,78 & 7,68 & 37,02 \\
100 & 21,60 & 4,02 & 4,78 & 0,12 & 1,89 & 0,87 & 5,15 & 2,90 & 8,05 & 36,89 \\
300 & 22,29 & 4,03 & 4,64 & 0,32 & 1,71 & 0,74 & 5,19 & 2,76 & 7,95 & 35,05 \\
F & ns & ns & ns & $\star \star$ & $\star \star$ & $\star \star$ & $\star \star$ & ns & $\star \star$ & ns \\
Reg. lin. & ns & ns & ns & $\star \star$ & $\star \star$ & $\star \star$ & $\star \star$ & ns & $\star \star$ & ns \\
Reg. quad. & ns & ns & ns & $\star$ & ns & $\star \star$ & $\star$ & ns & $\star \star$ & ns \\
\hdashline C.V. (\%) & $\mathbf{3 6 , 2}$ & $\mathbf{8 , 0}$ & $\mathbf{4 , 8}$ & $\mathbf{2 9 , 4}$ & $\mathbf{1 2 , 9}$ & $\mathbf{1 3 , 5}$ & $\mathbf{9 , 2}$ & $\mathbf{1 2 , 0}$ & $\mathbf{5 , 8}$ & $\mathbf{1 0 , 5}$
\end{tabular}

*,$\star \star$ e ns = significativo aos níveis de $5 \%$ e $1 \%$ e não significativo, respectivamente.

Médias seguidas da mesma letra, em cada coiuna, não diferem entre si pelo teste de Tukey (5\%). 
Alem da comprovação daqueles efeitos gerais da calagem já mencionados, pode-se notar na Tabela 3, variaçóes significativas entre os resultados obtidos para os cultivares. Houve diferença significativa (P $<0,01)$ na materia orgânica $e$ no pH do solo para os cultivares, identificando diferenças no comportamento dos cultivares.

Ds niveis de calcário empregados no solo reduziram linearmente $O H+A l, K$ e CTC $e$ incrementaram linearmente o pH, soma de bases, calcio e o magnesio trocaveis (Tabela 4 e Figuras 2 e 3 ), até 0 valor de 2,28 e 1,05 equivalentes-miligrama por 100 centimetros cúbicos de solo, respectivamente. Esses valores estão acima do valor critico para solo com pastagem (de 1,0 equivalente-miligrama por 100 centimetros cúbicas de solo) apontado por WERWER (1977).

o nivel máximo de calcário empregado 12850 kg/ha), resultou em porcentagem de saturação por bases (V\%) com um valor de 45,6\% (ao final do experimento), bem próximo da porcentagem de saturaçăo por bases do solo original, de 45\%: verificando-se um efeito linear (Tabela 4). Esse paråmetro não mostrou variaçăo significativa para as doses de potásio testados.

As doses de potássio aplicadas ao solo 10,100 $300 \mathrm{~kg} \mathrm{~K} / \mathrm{ha}$, , na forma de $\mathrm{KCl}$, aumentaram significativamente $(P<0,01)$ os niveis de potássio no solo, incrementando também a acidez do solo significativamente (P $<0,01)$ (Tabela 5 ). 
Tabela 4. Equaçỡes de regressão obtidas entre as variaveis estudadas no solo por ocasião da colheita final, para os niveis de calcário testados $10 ; 950 ; 1900$ e $2850 \mathrm{~kg} / \mathrm{ha}$ ) seus respectivos coeficientes de determinação $\left(R^{2}\right)$.

Variável estudada

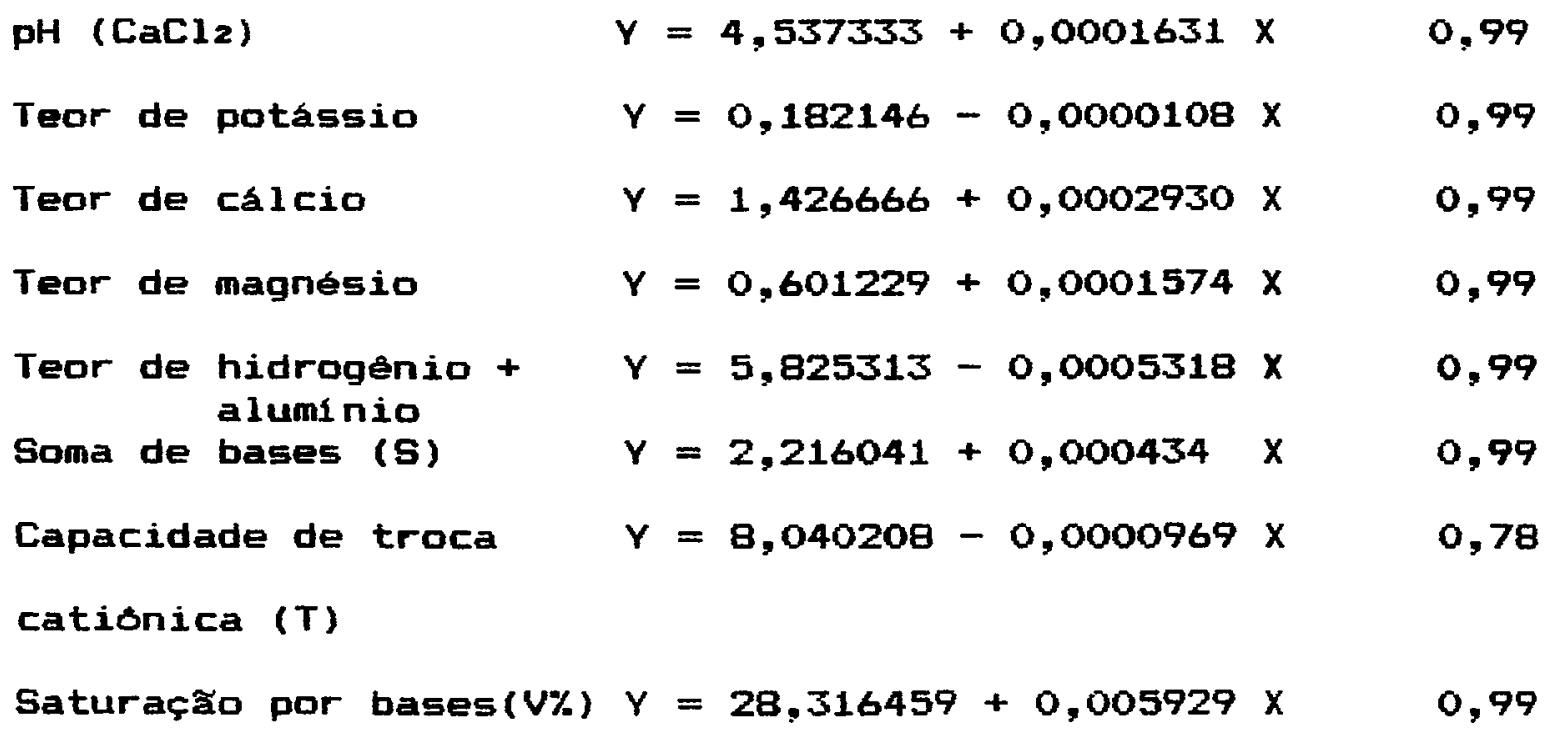

a. $Y$ o valor para a variável estudada enquanto $X$ a dose de calcário aplicada, dentro dos limites testados. 
Tabela 5. Equaçठ̋es de regressão obtidas entre as variáveis estudadas no solo por ocasiao da colheita final, para os niveis de potássio testados $10 ; 100$ e 300 $\mathrm{kg} / \mathrm{ha}$ ) seus respectivos coeficientes de determinação $\left(R^{2}\right)$.

Variável estudada

Teor de potássio

$$
\begin{array}{rlr}
Y= & 0,046875+0,0007078 x+ \\
& 0,00000077 x^{2} \\
Y= & 1,910938-0,0005008 x \quad 0,99 \\
Y= & 0,844687+0,0006268 x- \\
& 0,0000031 x^{2} &
\end{array}
$$

Teor de cálcio

Teor de magnésio

Tear de hidrogenio + $Y=4,906406+0,0032180 X-$ aluminio

$0,00000804 x^{2}$

0,99

Capacidade de troca $Y=7,681251+0,0050937 X-$ catiónica (T) $0,00001375 x^{2}$ 0,99

a. Y o valor para a variável estudada enquanto $X$ é a dose de potássio aplicada, dentro dos limites testados. 


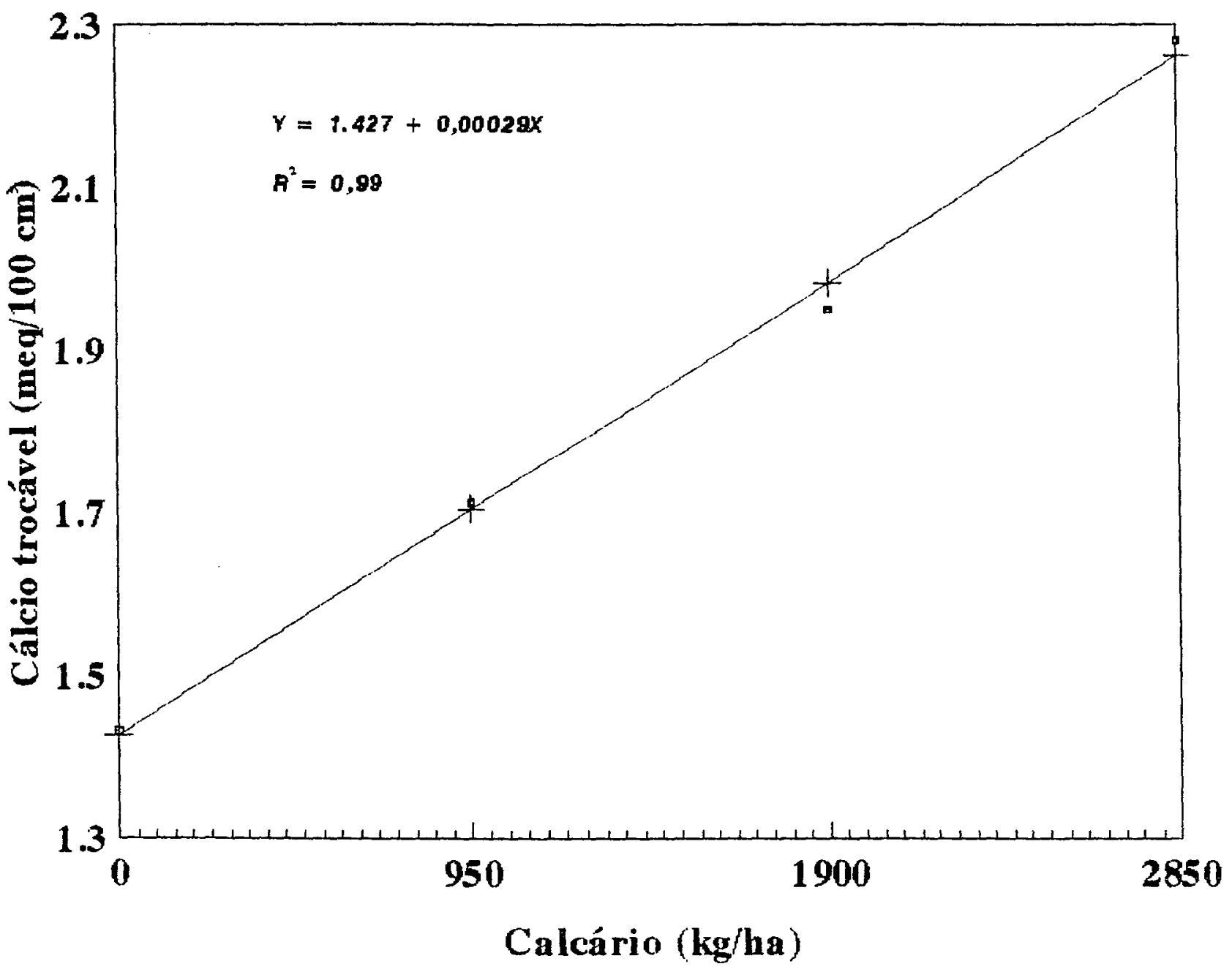

Figura 2 - Teor de calcio trocavel no solo por ocasião da colheita final, en função dos niveis de calcário aplicados. 


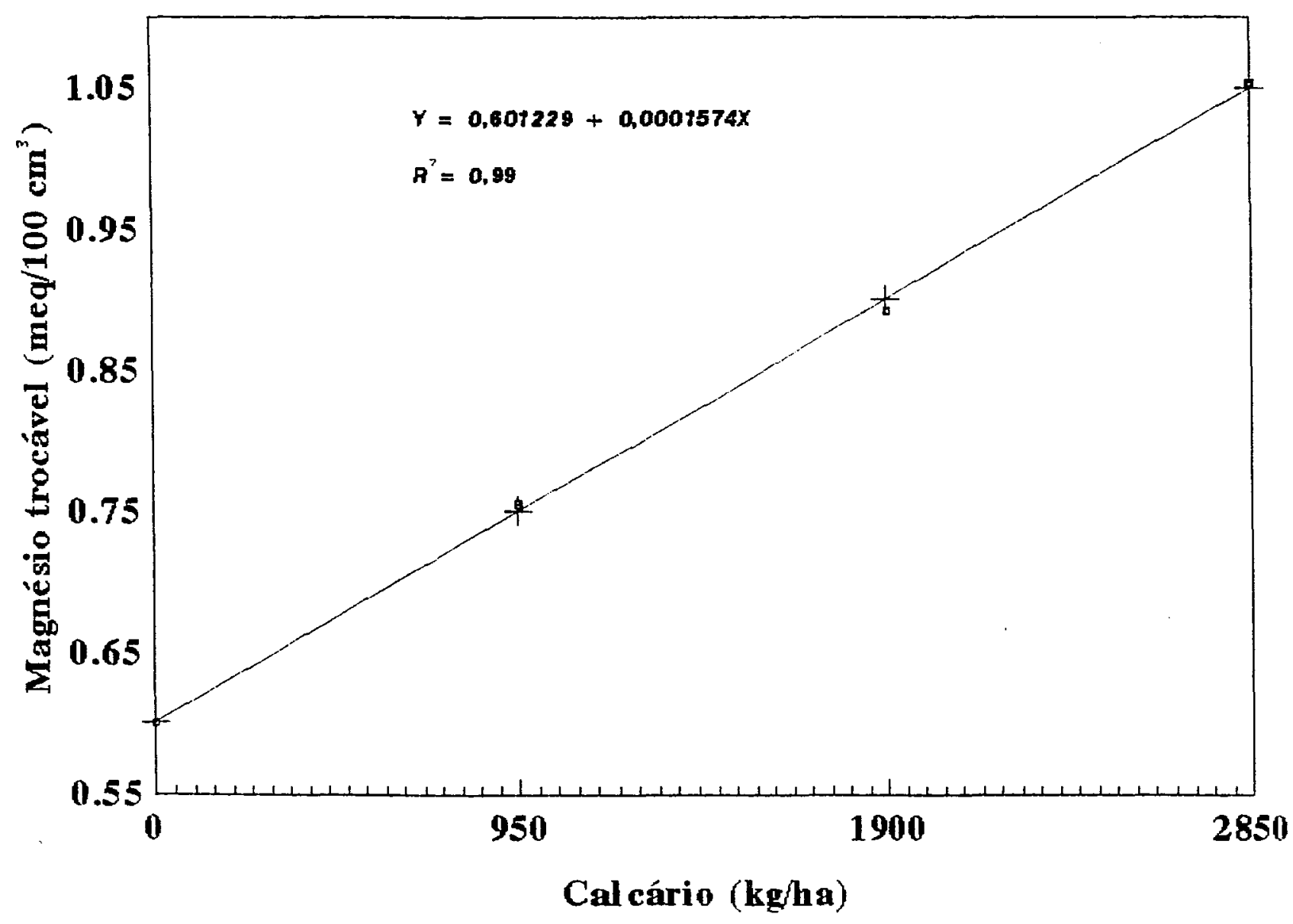

Figura 3 - Teor de magnésio trocável no solo por ocasião da colheita final, em funça dos niveis de calagem aplicados. 
As alteraçôes no $\mathrm{pH}$, nos teores de fosforo e de matéria orgânica, induzidas pela aplicaça do potássio não foram significativas ( $P>0,05)$. Quanto a capacidade de troca de cátions (T), para as três niveis de potássio aplicados, houve variaçăo significativa $(P<0,01)$, sendo a dose de $185 \mathrm{~kg} \mathrm{~K} / \mathrm{ha}$ correspondente ao ponto de máximo, conforme a equaçăo de regressão na Tabela 5.

Uma calagem adicional para elevar o pH acima daquele no qual todo o aluminio tenha sido neutralizado afetaria a capacidade de troca de cátions efetiva por desprotonação de sitios dependentes de pH. Nao se sabe se este tratamento teria o mesmo efeito no potássio da solução do solo como as reaçóes nas quais a capacidade de troca de cátions foi aumentada pela remoção do aluminio, segundo GOEDERT et al. (1975). Acrescentaram esses autores que onde a materia orgânica é a fonte principal da capacidade de troca catiónica (CTC), o aumento da capacidade tampão do potássio, a medida que o CTC e aumentado pela calagem, náo deveria ser tão rápida quanto no caso em que há neutralização do aluminio.

Ds teores de magnésio trocável diferiram estatisticamente, com significancia ao nivel de $1 \%$ e efeito quadratico (Tabela 5 e Figura 4) para as doses de potassio aplicadas. 0 ponto de maximo, atraves da equaça de regressão, é alcançado com $101 \mathrm{~kg} \mathrm{K/ha.}$

Pelos resultados da Tabela 3 , constata-se que 
- cálcio trocável do solo atingiu o valor mínimo de 1,71 meq/100 $\mathrm{cm}^{3}$, quando se aplicou o maior nivel de potássio (Figura 5), caracterizando um efeito negativo e linear. Pela equação de regressão que se encontra na Tabela 5, o valor máximo foi de $1,91 \mathrm{meq} / 100 \mathrm{~cm}^{3}$.

Os niveis de calcário aplicados ao solo incrementaram os valores de pH linearmente (Tabela 4). a pH 5,00 foi o maior valor encontrado para a maior dose de calcário testada (2850 kg/ha), diferindo en $11 \%$ do pH inicial.

Quanto à soma de bases (5) houve efeito linear (Tabela 4) para as doses de calcário aplicado, sendo a diferença de $64 \%$ entre a ausencia de calagem a a dose de 2850 kg/ha. Durante o decorrer de todo o experimento essa diferença em porcentagen dos valores da soma de bases (9) se manteve.

Os teores de potássio apresentaram variação significativa $(P<0,05)$ efeito linear negativo (Tabela 4) e efeito quadratico (Tabela 5 ) para as doses de calcario e de potássio, respectivamente.

Os niveis de calcário e adubação potássica não apresentaram diferenças significativas nos teores de fósforo e matéria orgânica.

Ds valores encontrados para capacidade de troca catiónica mostraram efeito linear negativo (Tabela 4) quanto aos niveis de calagem testados. 


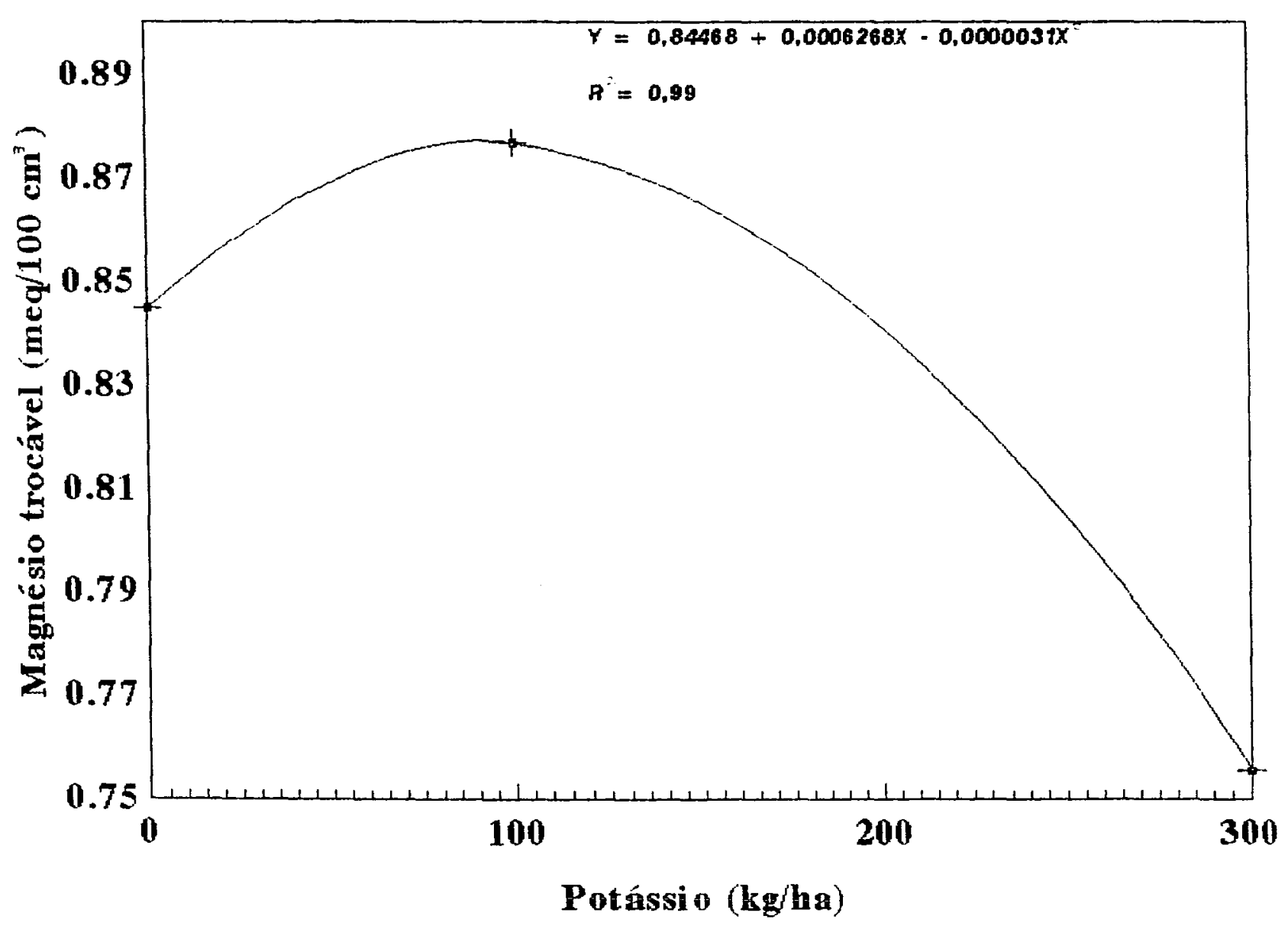

Figura 4 - Teor de magnésio trocável no solo por ocasiăo da colheita final, en função dos niveis de potássio aplicado. 


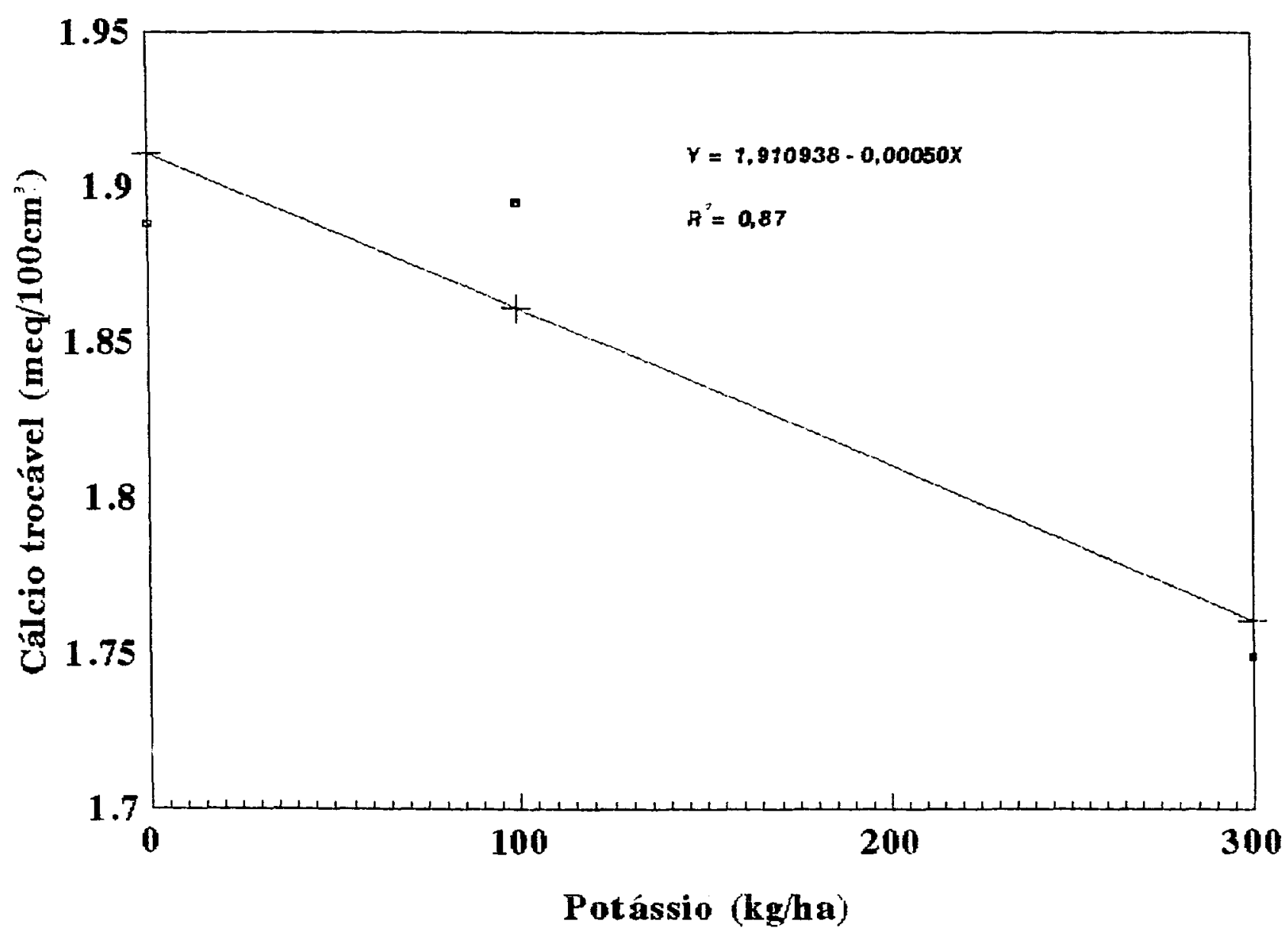

Figura 5 - Teor de cálcio trocável no solo por ocasião da colheita final, en função dos niveis de potássio aplicados. 
RAIJ (1991) ressaltou que os solos ricos en cálcio, apresentam maior capacidade de troca de cátions, condiçôes essas que contribuem para reduzir um pouco a disponibilidade de potássio. En presença de teores mais elevados de cálcio e magnésio trocáveis no solo, os mesmos teores de potássio trocável podem se revelar menos disponíveis para certas culturas.

$$
\text { A calagem aumentou linearmente }
$$

a disponibilidade de cálcio e de magnésio no solo (Tabela 4).

\subsection{Efeitos na planta}

\subsubsection{Produçao de matéria seca e nitrogenio na plante}

Os resultados relativos à produçăo de materia seca, porcentagem de nitrogenio e quantidade total de nitrogênio para os quatro cultivares, os quatro niveis de calagem e os tres niveis de adubação potássica, estão apresentados nas Tabelas 6 e 7, para o primeiro corte e 0 segundo corte, respectivamente e na Tabela 8 para raizes. As equaçớs de regressão e seus respectivos coeficientes de determinação relativos as respostas aos niveis de calcário e de potássio estão apresentados nas Tabelas 9 a 12 . 
Tabela 6. Produção de materia seca, porcentagem de nitrogenio e quantidade total de nitrogenio na parte aerea do primeiro corte (70 dias), em função dos cultivares e dos niveis de calcário e de potássio. Médias de quatro repetiçóes.

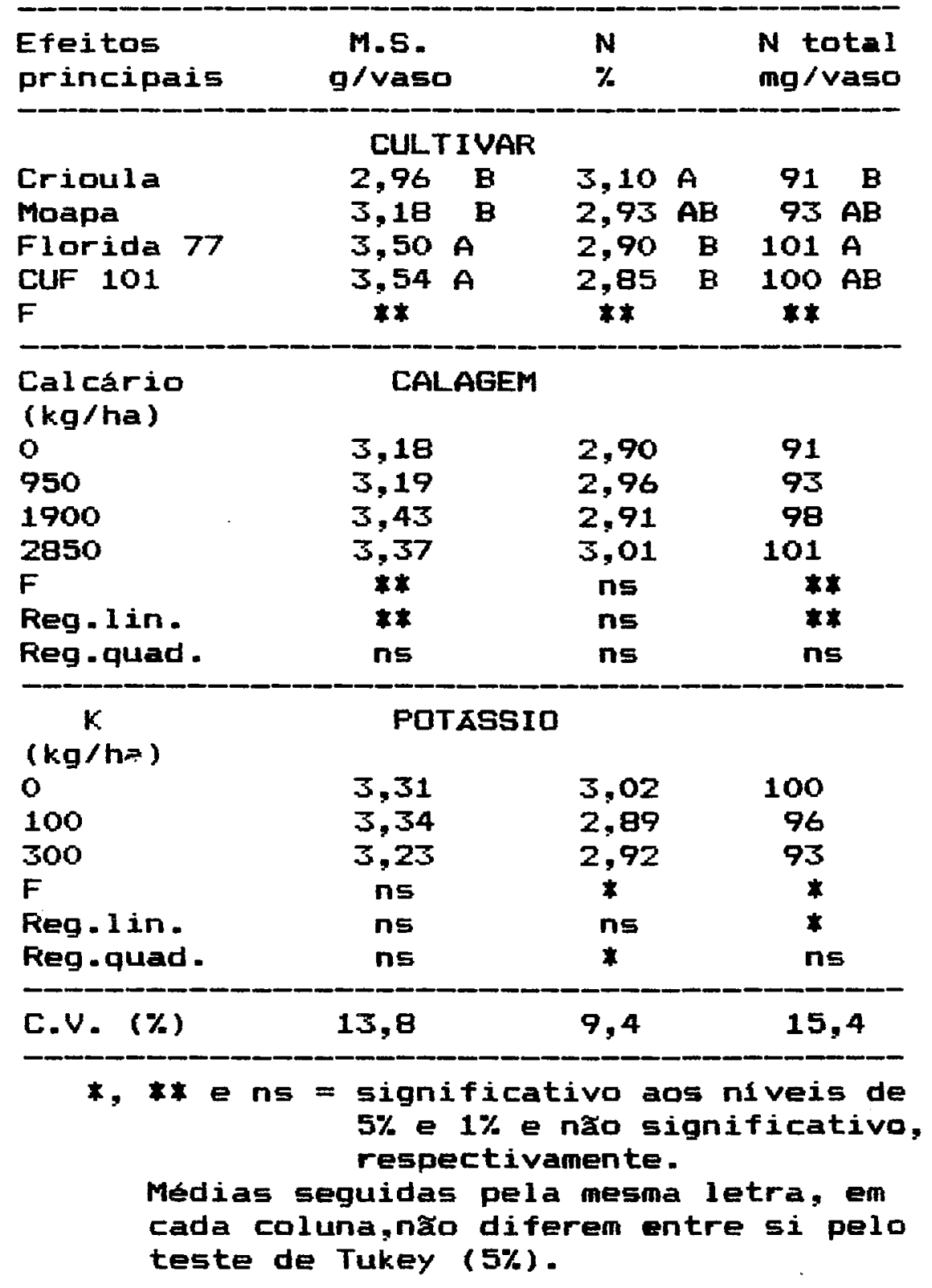


Tabela 7. Produção de materia seca, porcentagen de nitrogenio e nitrogénio total na parte aérea do segundo corte (104-111 dias), em função dos cultivares dos niveis de calcário e de potássio. Média de quatro repetiçóes.

\begin{tabular}{|c|c|c|c|c|}
\hline $\begin{array}{l}\text { Efeitos } \\
\text { principais }\end{array}$ & $\begin{array}{l}\text { M.S. } \\
\text { g/vaso }\end{array}$ & $\begin{array}{l}N \\
\%\end{array}$ & & $\begin{array}{l}N \text { total } \\
\text { mg/vaso }\end{array}$ \\
\hline \multicolumn{5}{|c|}{ CULTIVAR } \\
\hline $\begin{array}{l}\text { Crioula } \\
\text { Moapa } \\
\text { Flarida } 77\end{array}$ & $\begin{array}{l}4,72 \mathrm{~A} \\
4,72 \mathrm{~A} \\
4,80 \mathrm{~A}\end{array}$ & $\begin{array}{l}2,96 \\
2,73 \\
2,80\end{array}$ & $\begin{array}{r}\mathrm{A} \\
\mathrm{AB}\end{array}$ & $\begin{array}{l}141 \mathrm{~A} \\
129 \mathrm{~A} \\
135 \mathrm{~A}\end{array}$ \\
\hline $\begin{array}{l}\text { CUF } 101 \\
F\end{array}$ & $\begin{array}{c}4,99 \mathrm{~A} \\
\mathrm{~ns}\end{array}$ & $\begin{array}{c}2,64 \\
* *\end{array}$ & B & $\begin{array}{c}132 \mathrm{~A} \\
\text { ns }\end{array}$ \\
\hline
\end{tabular}

Calcário

CALAGEM

(kg/ha)

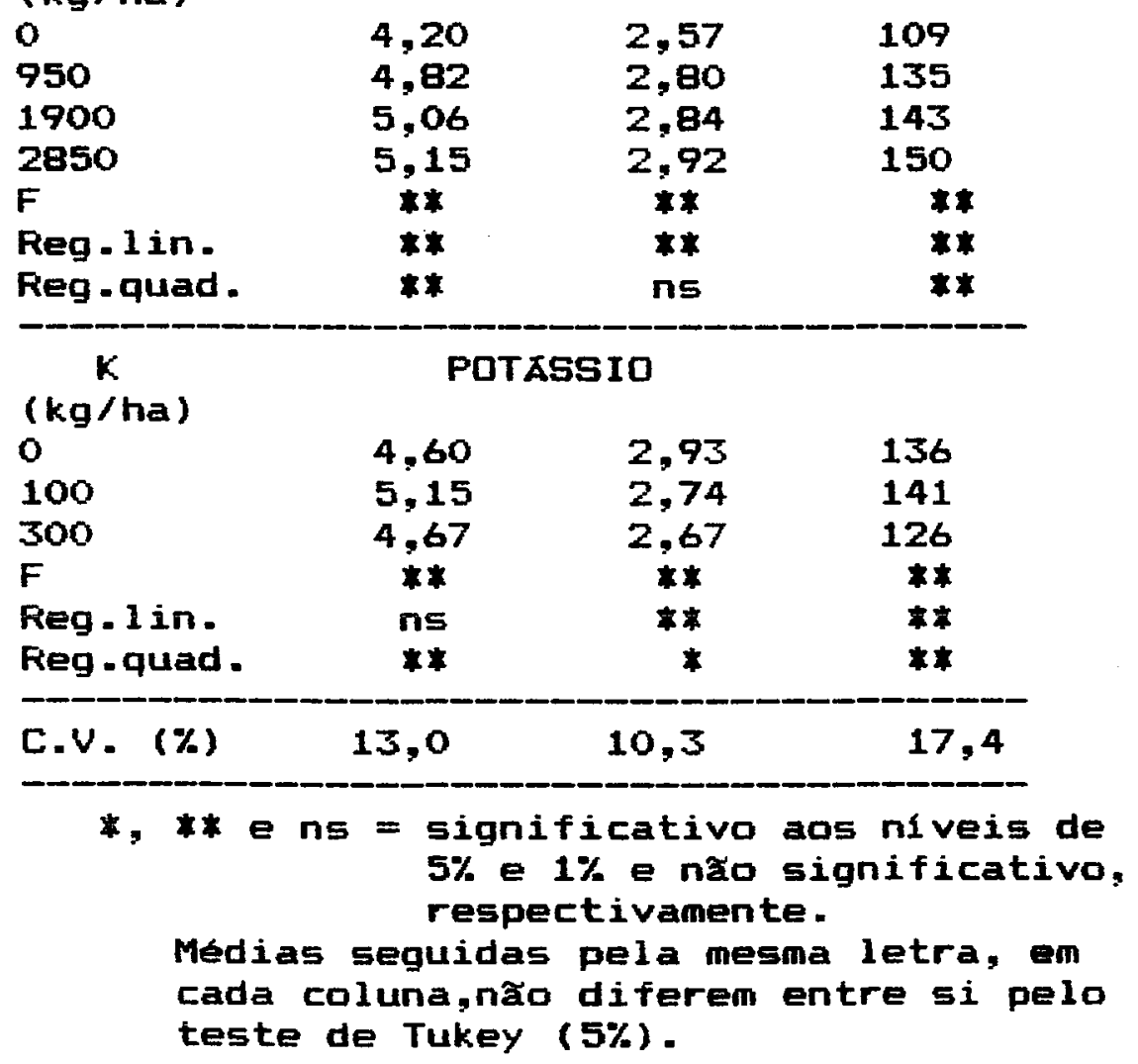


Tabela 8. Produção de matéria seca, porcentagem de nitrogénio e quantidade total de nitrogenio nas ralzes, en funçáo dos cultivares, dos niveis de calcário e potássio. Medias de quatro repetiçzes.

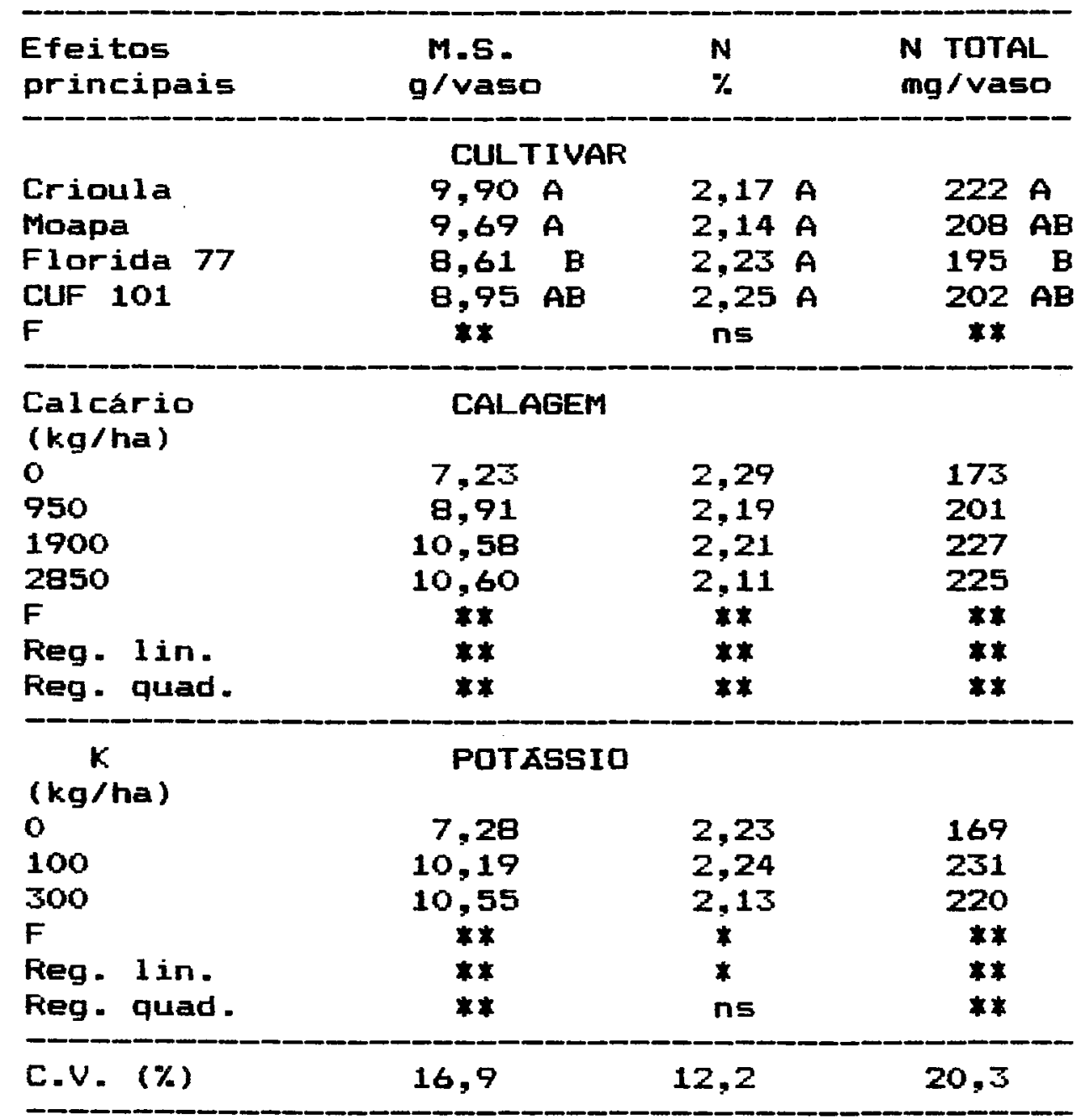

$$
\begin{aligned}
* * * \text { e ns }= & \text { significativo aos niveis de } \\
& 5 \% \text { e } 1 \% \text { e não significativo, } \\
& \text { respectivamente. }
\end{aligned}
$$

Médias seguidas pela mesma letra, em cada coluna,não diferem entre si pelo teste de Tukey $(5 \%)$. 
Tabela 9. Equaçớes de regressão obtidas entre a produção de matéria seca e a quantidade de nitrogenio total na parte aerea da da alfafa, para os niveis de calcário testados $10 ; 950 ; 1.900$ a 2.850 $\mathrm{kg} / \mathrm{ha}$, referentes ao primeiro e segundo cortes da planta a porcentagem de nitrogénio no segundo corte, e seus respectivos coeficientes de determinação $\left(R^{2}\right)$.

\begin{tabular}{|c|c|c|}
\hline Variável estudada & Equaçăo de regressao & $\mathbf{R}^{2}$ \\
\hline
\end{tabular}

1ㅇ CORTE

Materia seca

$Y=3,171+0,000086 x$

0,67

Nitrogénio total

$Y=91,188+0,00363 x$

0,97

2으 CORTE

Materia seia

$$
\begin{aligned}
r= & 4,207+0,00075 x- \\
& 0,00000015 x^{2}
\end{aligned}
$$

Teor de nitrogenio

$$
Y=2,619+0,000113 x
$$

Nitragenio total

$$
Y=109,66+0,0290 \times-
$$

$$
0,0000053 x^{2}
$$

0.98

a. Y o valor para a variável estudada enquanto $X$ é a dose de calcário aplicado, dentro dos limites testados. 
Tabela 10. Equaç̧es de regressão obtidas entre a produçao de materia seca, a porcentagem de nitrogenio e a quantidade de nitrogénio total na parte aérea da da alfafa,para os niveis de potássio testados 10 ; 100 e $300 \mathrm{~kg} / \mathrm{ha}$, referentes a primeiro e segundo cortes da planta e seus respectivos coeficientes de determinação $\left(R^{2}\right)$.

Variável estudada

Equação de regressão

$R^{2}$

1으 CORTE

Teor de nitrogenio

$$
\begin{aligned}
& Y=3,023-0,00185 x+ \\
& 0,00000504 x^{2} \\
& 0,99 \\
& Y=99,039-0,0201 x
\end{aligned}
$$

Nitrogénio total

2으 CORTE

Matéria seca

$$
\begin{gathered}
Y=4,604+0,00815 x- \\
0,0000265 x^{2} \quad 0,99
\end{gathered}
$$

Teor de nitrogenio

$$
\begin{gathered}
Y=2,929-0,00237 x+ \\
0,0000050 x^{2}
\end{gathered}
$$$$
0,99
$$

Nitrogennio total

$$
\begin{gathered}
Y=135,93+0,09879 x- \\
0,000442 x^{2}
\end{gathered}
$$$$
0.99
$$

a. $Y e$ o valor para a variável estudada enquanto $X$ a dose de potássio aplicado, dentro dos limites testados. 
Tabela 11. Equaçరes de regressao obtidas entre a produça de materia seca, a porcentagem de nitrogénio e a quantidade de nitrogenio total nas ralzes da alfafa para os niveis de calcário testados (0) 950; 1.900 a $2.850 \mathrm{~kg} / \mathrm{hal}$ e seus respectivos coeficientes de determinação $\left(R^{2}\right)$.

Variável estudada

Equação de regressão $\mathbf{R}^{2}$

Matéria seca

$$
\gamma=
$$$$
8,007+0,00177 \times-
$$

$$
0,0000004 x^{2}
$$$$
0.99
$$

Teor de nitrogenio

$$
\begin{gathered}
Y=2,024+0,00025 \times- \\
0,000000055 x^{2}
\end{gathered}
$$

Nitragenio total

$$
\begin{aligned}
Y= & 165,08+0,0552 \times- \\
& 0,000012 x^{2}
\end{aligned}
$$$$
0,98
$$

a. Y é o valor para a variável estudada enquanto $X$ e dose de calcario aplicado, dentro dos limites testados. 
Tabela 12. Equaçớes de regressão obtidas entre a produçăo de materia seca, a porcentagem de nitrogenio e a quantidade de nitrogenio total nas ralzes da alfafa, para os niveis de potássin testados 10 ; 100 e $300 \mathrm{~kg} / \mathrm{ha}$ ) e seus respectivos coeficientes de determinaçăo $\left(R^{2}\right)$.

Variável estudada Equação de regressão $\mathbf{R}^{2}$

Materia seca $Y=7,236+0,0312 \times-$ $0,000091 x^{2} \quad 0,99$

Teor de nitrogenio $Y=2,248-0,00037 x$ 0,80

Nitrogenio total $Y=168.84+0,854 \times-$ $0,0023 x^{2}$ 0,99

a. $Y$ o valor para a variável estudada enquanto $X$ a a dose de potássio aplicado, dentro dos 1 imites testados. 
As produçơes de matéria seca da parte aérea verificadas no primeiro corte (Tabela 6) variaram significativamente $(P<0,01)$ entre os cultivares tegtados. Os cultivares de maior produçăo foram florida 77 e CUF 101. No segunda corte (Tabela 7) as produçชes de materia seca nă tiveram diferenças significativas $(P>0,05)$. Fara as raizes (Tabela 8$)$ houve diferenca significativa ( $P<0,01)$ na produção de matéria seca entre os cultivares testados, tendo - cultivar florida 77 se caracterizado como o cultivar de menor produção. Contudo, por ocasião do primeiro corte (Tabela 6): junto com o cultivar CuF 101, este obteve maior produção. Parece ter ocorrido uma tendéncia de acumular matéria seca na parte aérea, em detrimento da produçăo de matéria seca da raiz.

As produçớs de materia seca da parte aerea verificadas no primeiro corte (Tabela 6) foram significativamente $(P<0,01)$ aumentadas pela calagem apresentando efeito linear. Isto difere do segundo corte (Tabela 7), no qual o efeito foi quadratico (Figura 6) e as respectivas equaçơes de regressão encontram-se na Tabela 9. A alfafa normalmente tem mostrado respostas acentuadas à calagem. ADAMS \& PEARSON (1967), concluíram que a alfafa é responsiva a calagem, concordando com FREITAS \& PRATT (1969), KORNELIUS (1972), STAMMEL \& KORNELIUS (1973), RANDO (1992), entre outros.

Dbservando-se as produçరeses de matéria seca na 
Tabela 6, nota-se que para aplicação de potássio o efeito não foi significativo $(P>0,05)$. Isto foi diferente no segundo corte (Tabela 7), no qual o efeito foi quadratico, e a maior produçå de matéria seca correspondeu d dose de $154 \mathrm{~kg} \mathrm{K/ha,}$ conforme a equação de regressão da Tabela 10 e Figura 7. JONES \& FREITAS (1970), SANZONOWICZ \& VARGAS (1980), concluíram que o potássio teve efeito positivo na produção de matéria seca da alfafa, e segundo RANDO (1992), somente foi possivel constatar beneficios da adição de potássio, somente quando se eliminou a acidez do solo.

A porcentagen de nitrogenio na parte aerea da planta, tanto no primeiro como no segundo corte (Tabelas 6 e 7) mostrou variação significativa ( $<<0,01)$ entre os cultivares. A concentraça desse nutriente foi menor nos cultivares en que ocorreu simultâneo aumento na produçăo de materia seca, o que atribuiu para a queda do teor de nitrogénio devido a um efeito de diluição do elemento na planta.

A porcentagem de nitrogenio na parte aerea da planta, por ocasiăo do primeiro corte (Tabela 6) năo sofreu variação significativa com as doses de calcario aplicado. No segundo corte (Tabela 7), o efeito foi linear, com acréscimo simultâneo a um aumento na produçăo de matéria seca da parte aérea, refletindo os beneficios oriundos da correça da acidez do solo. Isso permite supor que ao tempo do primeiro corte a nodulação dessa leguminosa não estava en 
pleno funcionamento. Quanto à porcentagem de nitrogenio das raizes, para a calagem (Tabela B), o efeito foi quadratico com máximo en $2.500 \mathrm{~kg} / \mathrm{ha} e$ sua respectiva equação de regressão encontra-se na Tabela 11 e representada na Figura 8 .

JONES \& FREITAS (1970), SANZONOWICZ \& VARGAS (1980) e LEPSCH \& CLEMENTS (1985), concluí ram que a aplicação de potássio tem efeito positivo na quantidade extraida de nitrogénio no tecido das plantas.

Tanto no primeiro como no segundo corte (Tabelas 6 e 7), a porcentagem de nitrogenio na parte aérea, em função das doses de potássio, revelou um efeito quadratica, segundo as equaçőes de regressão da Tabela 10. Para as ralzes o efeito foi linear e negativo com respectiva equaçăo de regressão apresentada na Tabela 12 e na figura 8. 


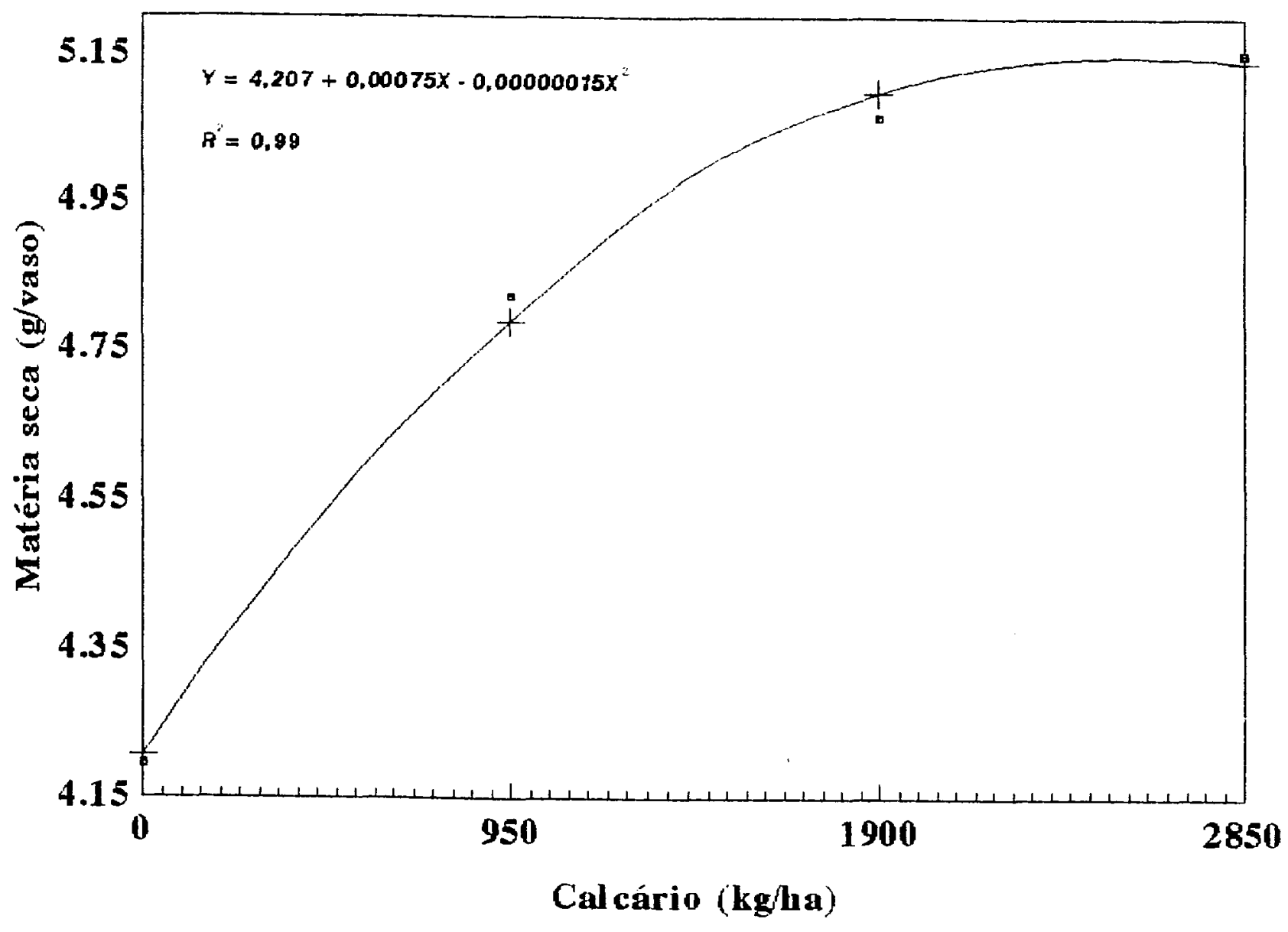

Figura 6 - Produção de materia seca da parte aerea do material colhido no segundo corte da alfafa, em funçăo do calcario aplicado. 


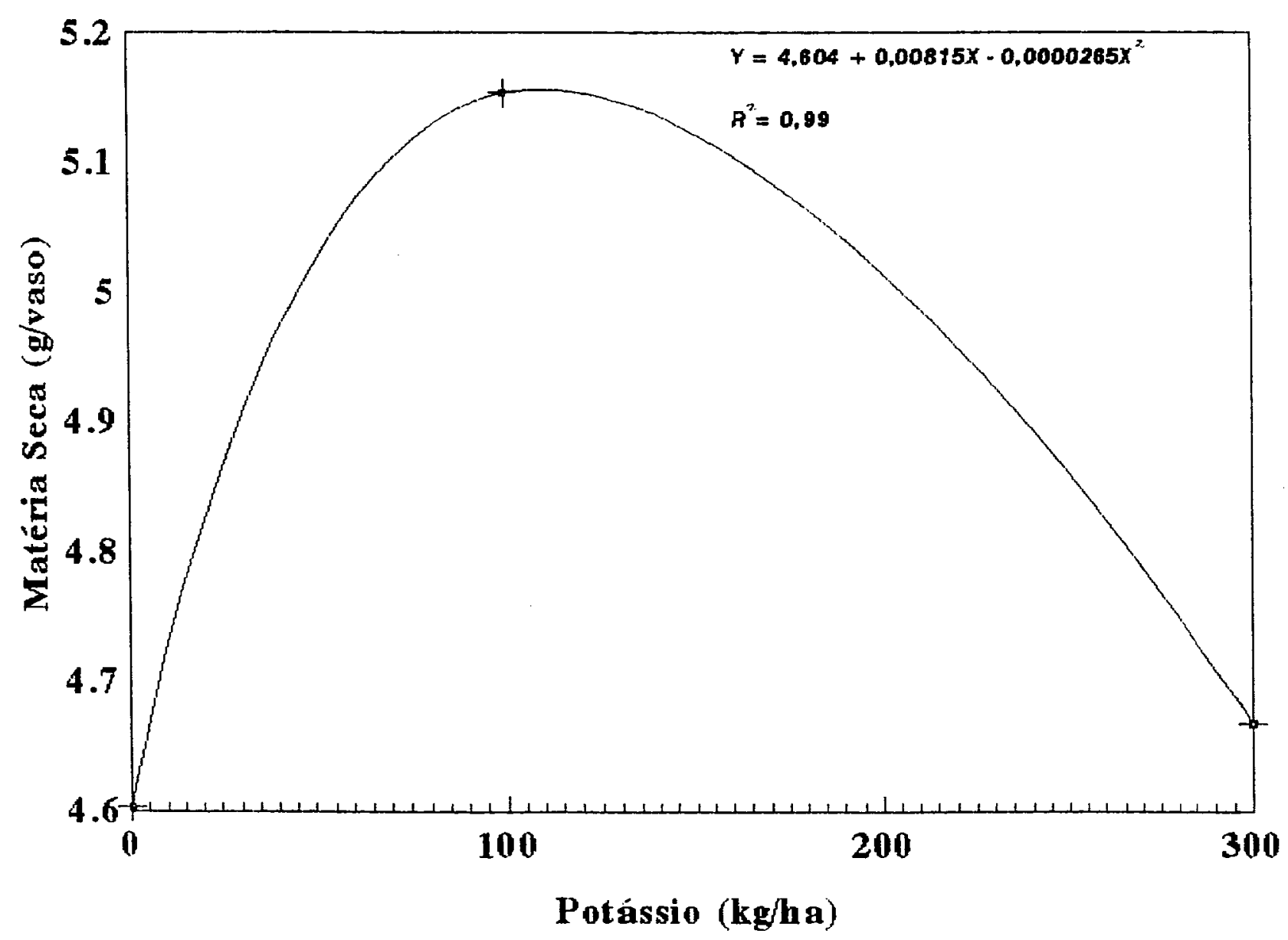

Figura 7 - Produção de materia seca da parte aérea do material colhido no segundo corte da alfafa, em função do potássio aplicado. 


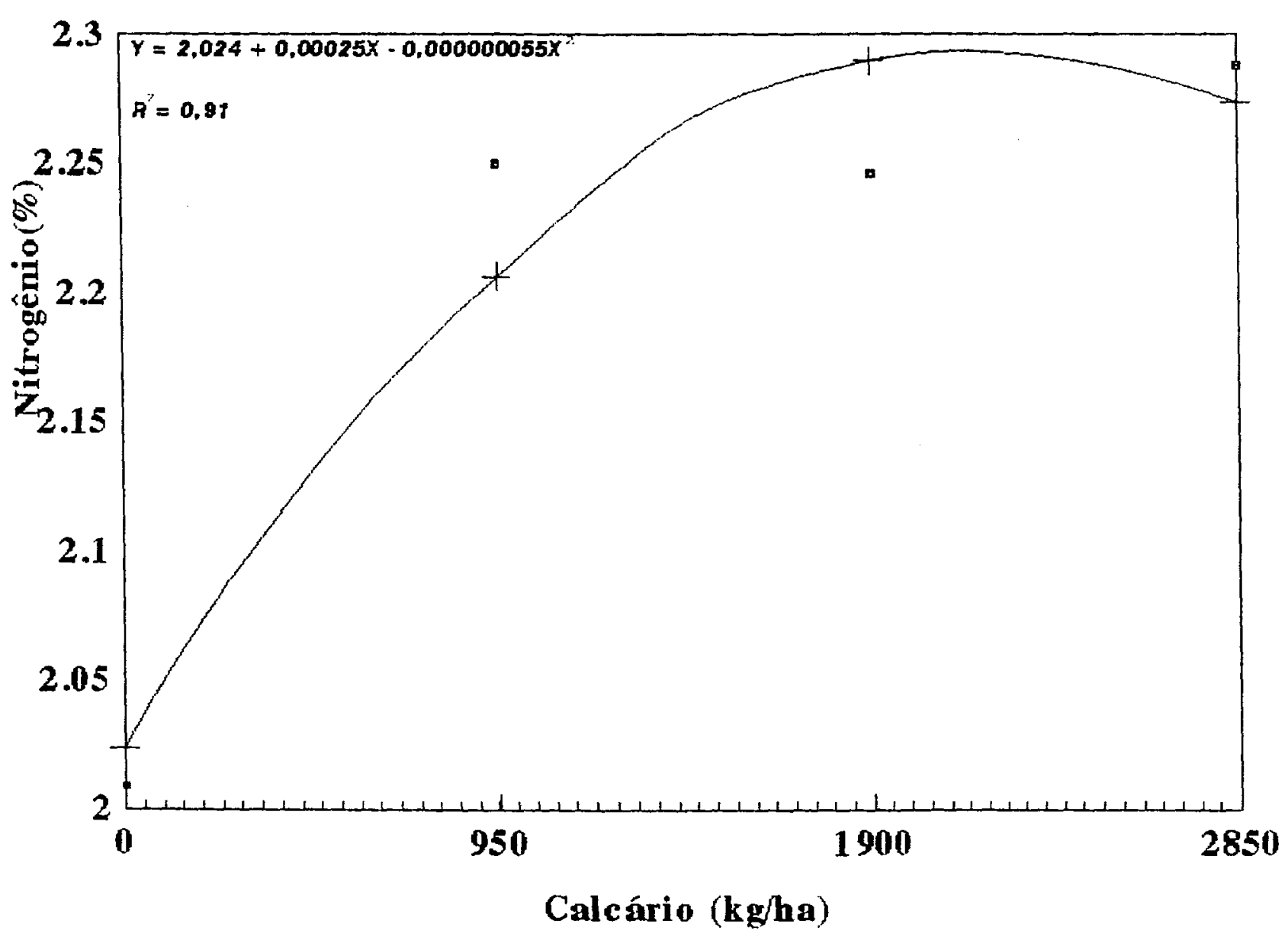

Figura 8 - Forcentagem de nitrogénio nas raizes de alfafa, en função do calcário aplicado. 


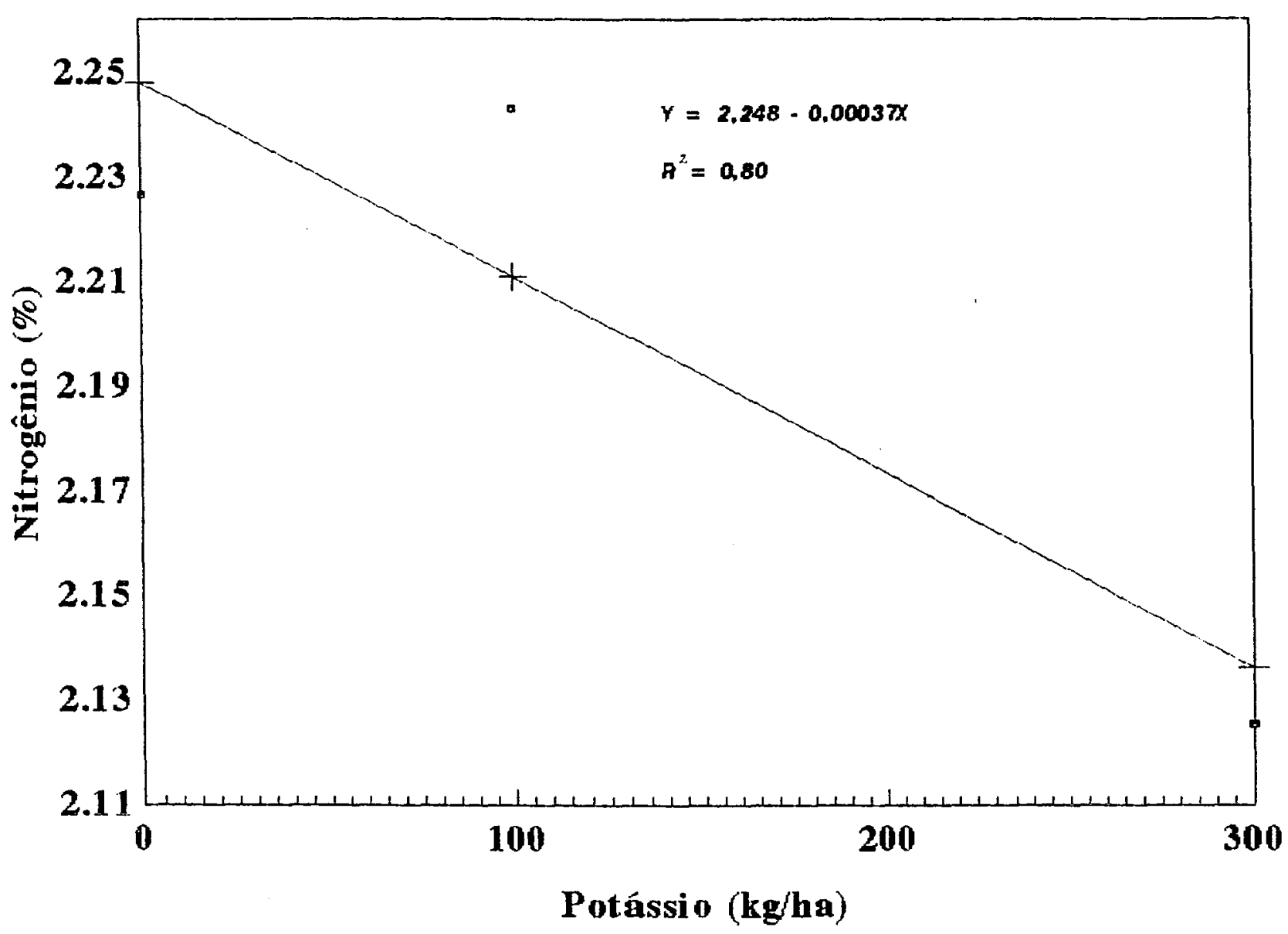

Figura 9 - Forcentagem de nitrogénio nas rafzes de alfafa, en função do potássio aplicado. 
Fara a quantidade total de nitrogénio na parte aérea da planta houve variação significativa $(P<0,01)$, por ocasião do primeiro corte (Tabela 6) para os cultivares testados. Foi evidente a superioridade do cultivar florida 77 en relação ao cultivar Crioula, enquanto os outros cultivares não diferiram entre si. No segundo corte (Tabela 7) não houve diferença significativa ( $F>0,05$ ) entre os cultivares: para essa variável. Em relação as rázes (Tabela 8) houve diferença significativa ( $P<0,01$ ) entre as cultivares Crioula e Florida 77, para essa variável testada, tendo os mesmos acumulado $222 \mathrm{mg} / \mathrm{vaso}$ e $195 \mathrm{mg} / \mathrm{vaso}$ respectivamente. Isto se deu ao contrário do resultado por ocasião do primeiro corte, podendo ressaltar a diferenca no estabelecimento dos cultivares.

Para os niveis de calcário o efeito foi linear e positivo, enquanto para os niveis de potássio foi linear e negativo, en relaçăo ao nitrogenio total da parte aerea no primeiro corte (Tabela 6 e Figuras 10 e 11). Parece ter havido nitida influencia no maior desenvolvimento das plantas com o consequente suprimento de carboidratos e de calcio, magnésio e potássio para os nódulos. Já no segundo corte (Tabela 7) verificou-se, para as doses de calagem e de potássio, um efeito quadrático com máximos em 2.736 e 112 kg/ha, representado pelas equaçסes de regressão mostradas nas Tabelas 9 e 10 e nas figuras 12 e 13 , respectivamente. 


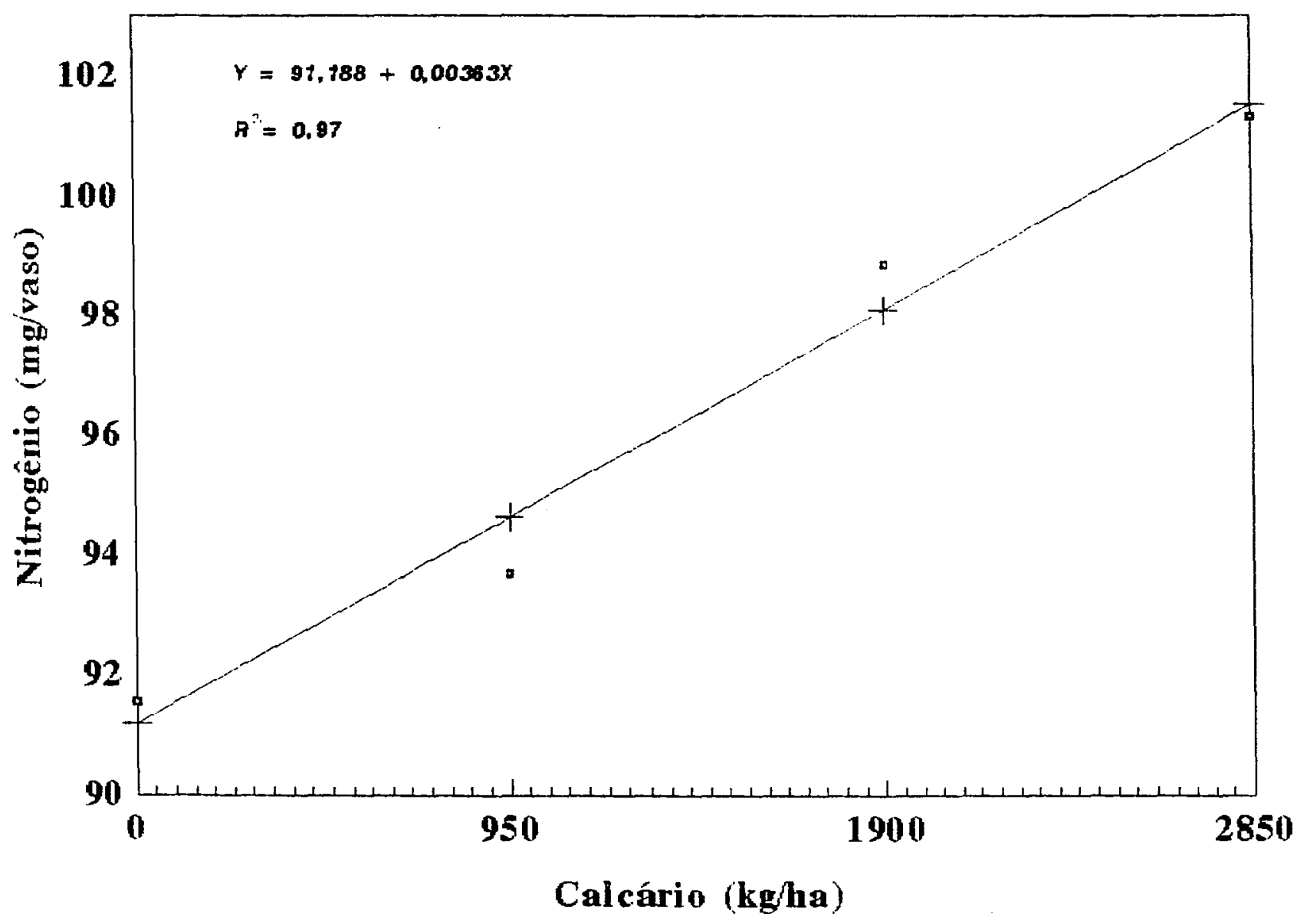

Figura 10 - Quantidade total de nitrogénio total na parte aérea da alfafe, no material colhido no primeiro corte, em funçăo do calcário aplicado. 


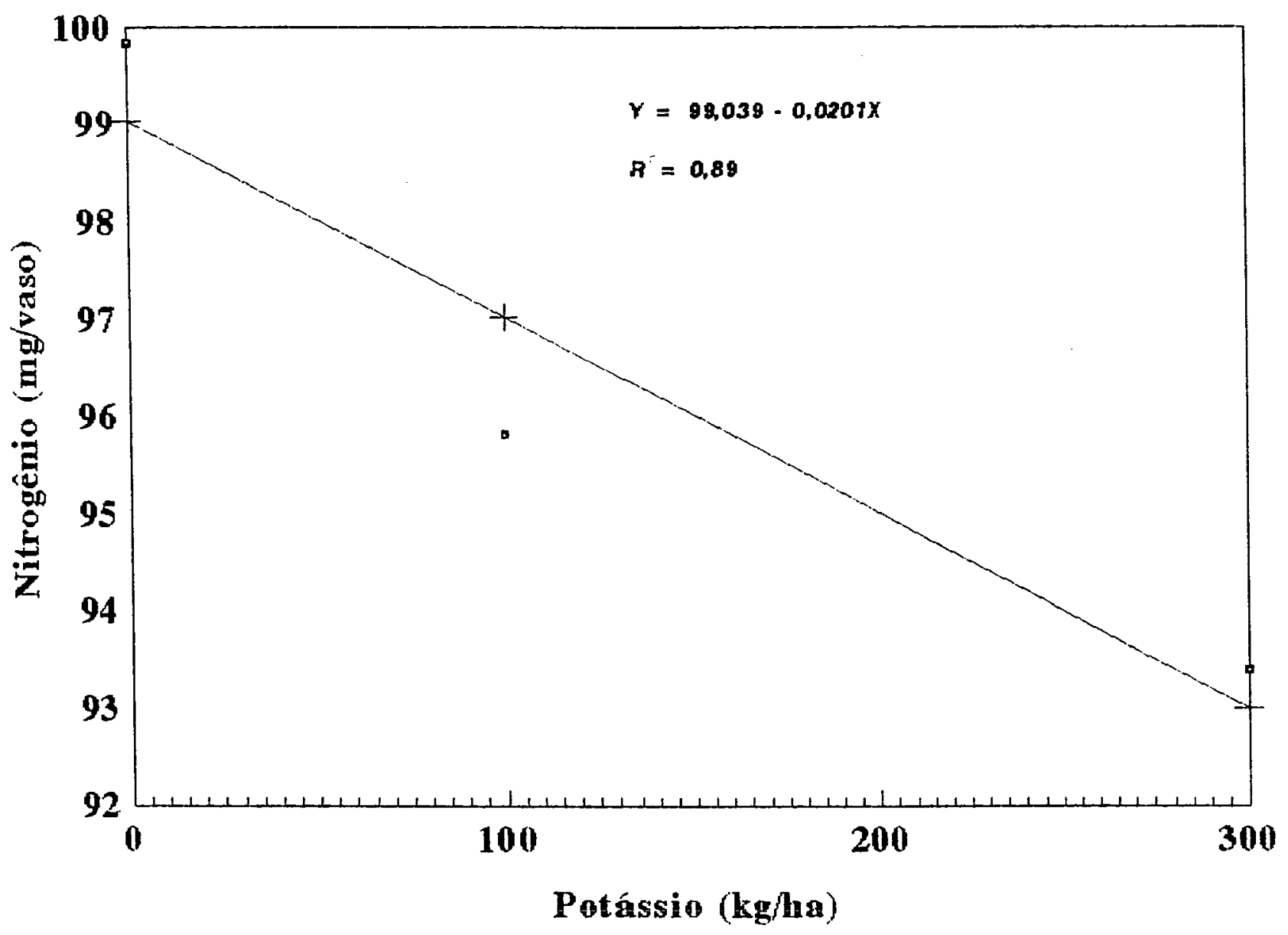

Figura 11 - Quantidade total de nitrogenio na parte aérea da alfafa, no material colnido no primeiro corte, en função do potássio apl i cado. 


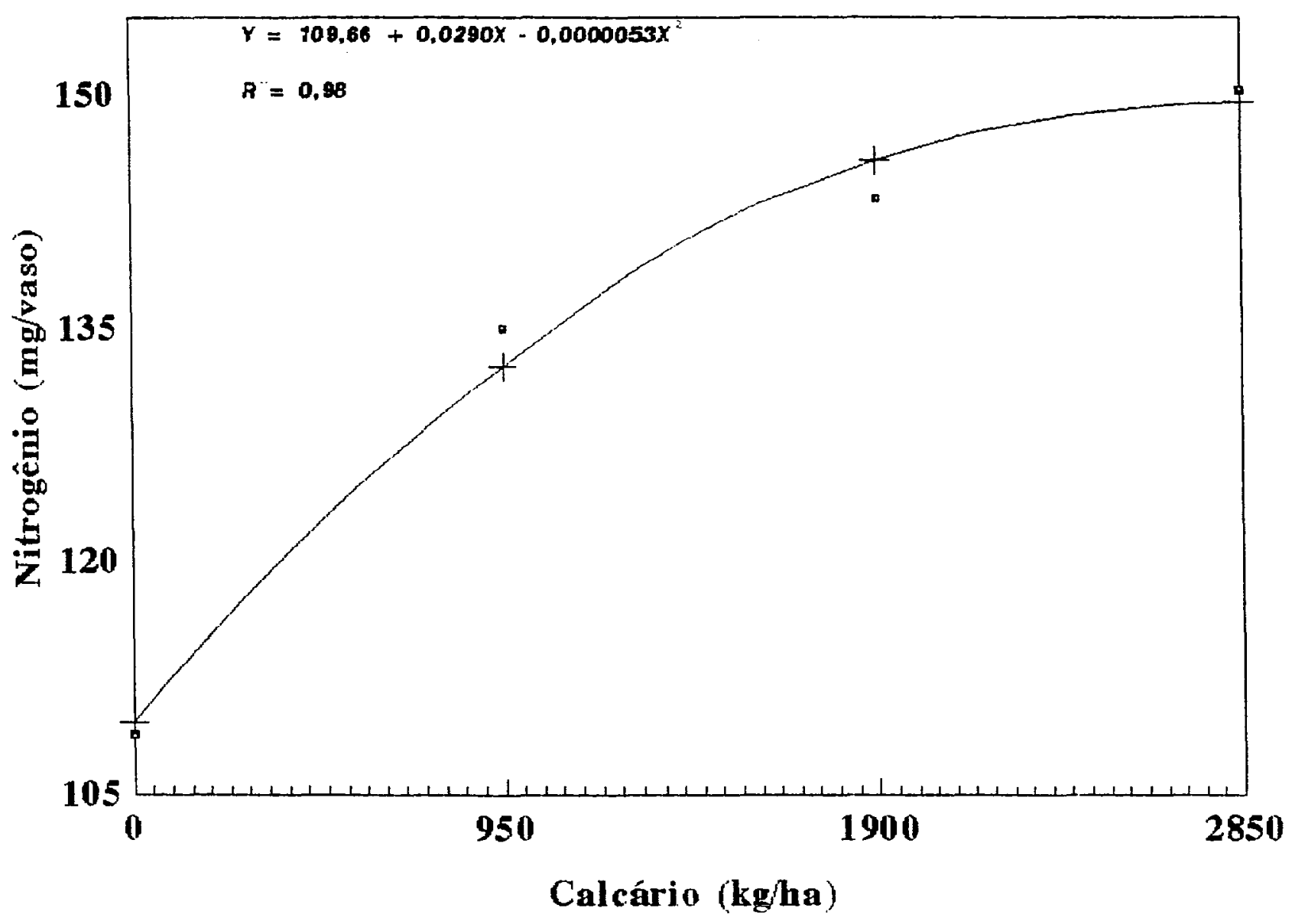

Figura 12 - Quantidade total de nitrogenio na parte aerea da alfafa, no material colhido no segundo corte, en função do calcário apl icado. 


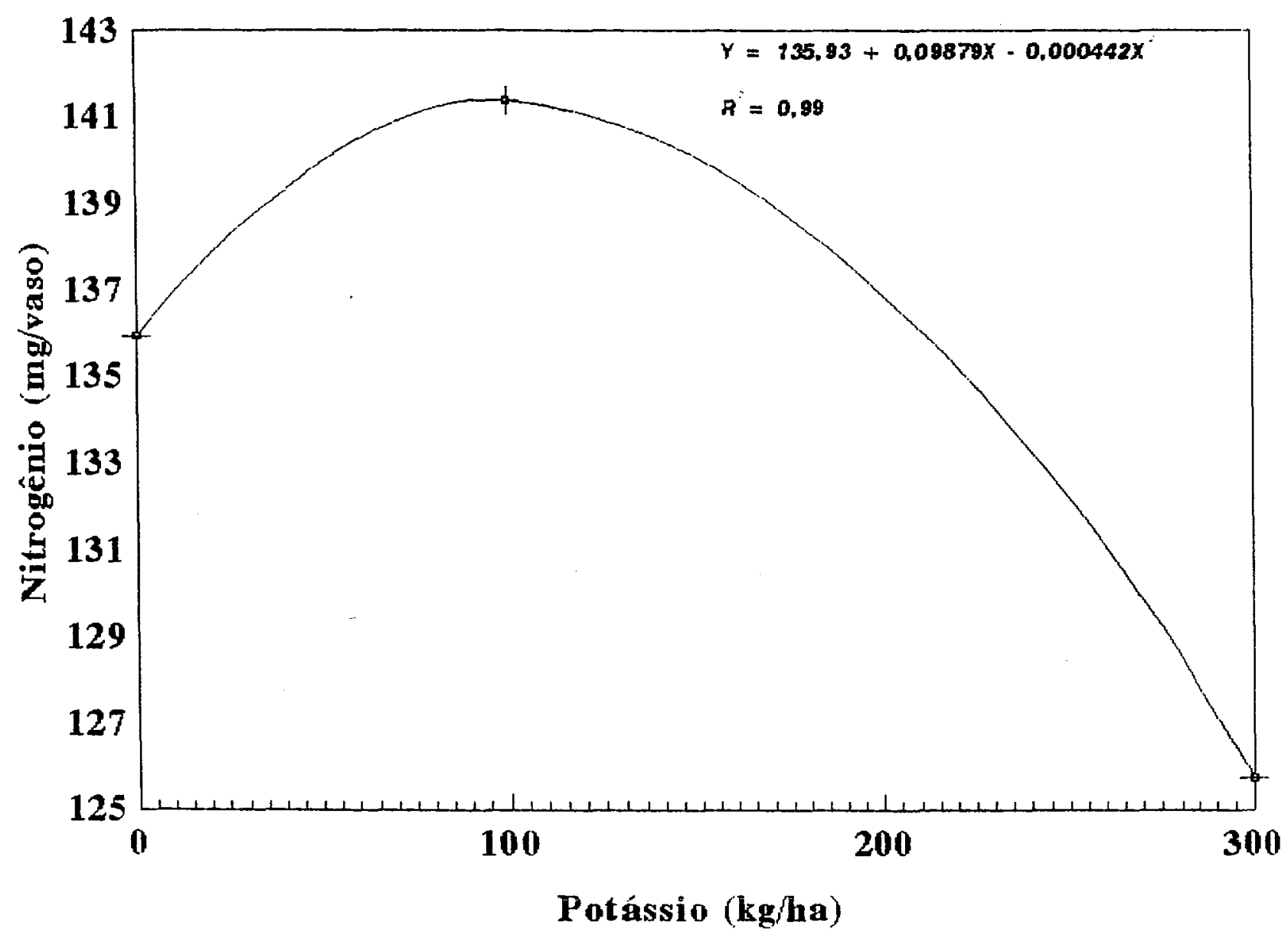

Figura 13 - Quantidade total de nitrogénio na parte aśrea da alfafa, no material colhido no segundo corte, em função do potássio aplicado. 
Em função do corretivo e do potássio aplicados ao solo verificou-se efeito quadrático em relação ao nitrogenio total das raizes (Tabela 8 ) cujas equaçóes de regressão encontram-se respectivamente, nas Tabelas 11 e 12 .

\subsubsection{Teores de macro e micronutrientes na planta}

Os resultados dos teores de macro e micronutrientes no material vegetal do primeiro e segundo cortes, para os quatro cultivares de alfafa e en funçăo dos quatro níveis de calagem $e$ dos tres niveis de adubação potássica, são apresentados nas Tabelas 13 a 16 . As equaçỡs de regressão para calagem e potássio, com os coeficientes de determinaçăo encontram-se nas Tabelas 17 a 20 .

De un modo geral, pode-se verificar que os valores abtidos estão dentro de valores normalmente encontrados na literatura. Cabe salientar que para os teores de fósforo no primeiro corte (Tabela 13), o cultivar Crioula teve teor significativamente $(P<0,01)$ superior ao CUF 101 . Para os teores de cálcio (Tabela 13), pode-se verificar diferença significativa $(P<0,05)$ entre os cultivares, sendo que o cultivar Moapa apresentou teor de cálcio superior ao do cultivar Crioula. Para potássio, magnésio e enxofre não foram detectadas diferenças significativas $(P>0,05)$ entre os cultivares. 
Tabela 13. Teqres de fósforo, potássio, cálcio, magnésio e enxofre na parte aerea no primeiro corte (70 dias após a plantio), en função dos cultivares $e$ dos niveis de calcário e de potássio. Média de quatro repetiçós.

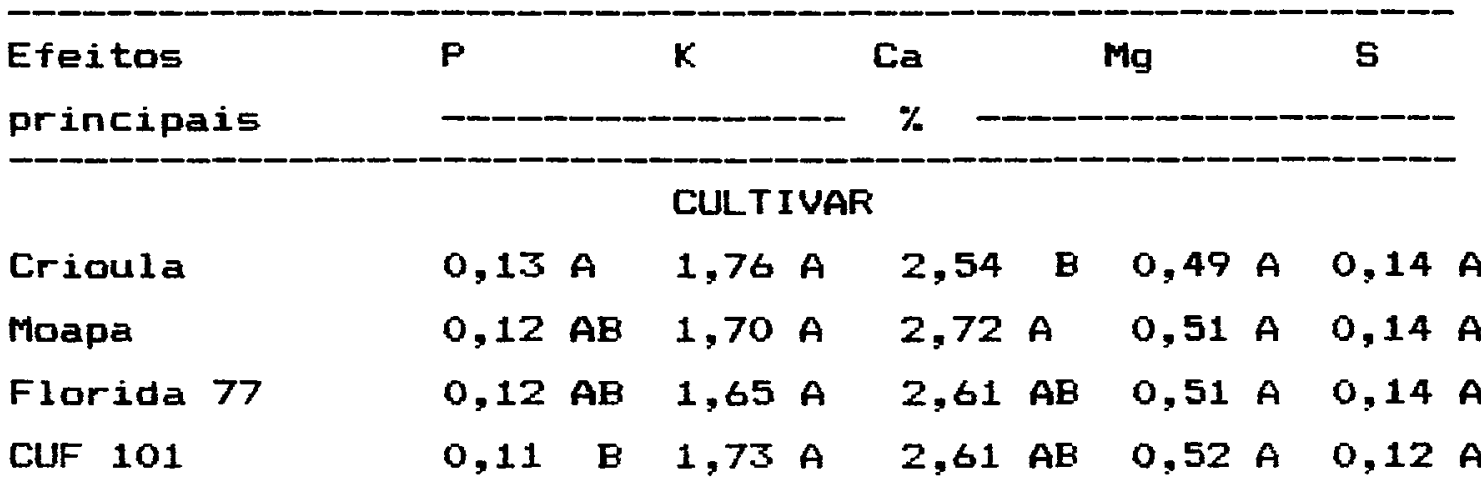

$F$ t*

ns

ns

ns

\section{Calcário}

calagem

(kg/ha)

$$
0
$$

0,12

1,80

2,55

0,47

0,13

950

0,12

1.77

2,64

0,50

0,13

1900

0,12

1,64

2,65

0,52

0,13

2850

0,12

1,63

2,64

0,56

0,15

$F$

ns

ns

ก5

**

ns

Reg - Iin.

ns

ns

ns

**

ns

Reg - quad.

$\mathbf{n} \mathbf{5}$

ns

ns

n与

$\mathbf{n} \mathbf{5}$

$k$

(kg/ha)

\begin{tabular}{|c|c|c|c|c|c|}
\hline 0 & 0,13 & 0,63 & 2,77 & 0.65 & 0,15 \\
\hline 100 & 0,12 & 1,77 & 2,62 & 0,48 & 0,13 \\
\hline 300 & 0.11 & 2,73 & 2,47 & 0,40 & 0,13 \\
\hline$F$ & $* *$ & $* *$ & $* *$ & $* *$ & $* *$ \\
\hline Reg - 1 in. & $* *$ & $* *$ & ** & $* *$ & $* *$ \\
\hline Reg - quad . & $* *$ & $* *$ & $n s$ & $* *$ & ns \\
\hline C.v. (\%) & 16,8 & 23,2 & 10,8 & 12,8 & 29,6 \\
\hline
\end{tabular}

Módias seguidã significativo, respectivanente.

nao diferem entre $5 i$ pelo teste de Tukey (5\%). 
Tabela 14. Teores de fósforo, potássio, cálcio, magnésio e enxofre na parte aerea no segundo corte (104 dias apos o plantio), em função dos cultivares, $e$ dos niveis de calcário e de potássio. Media de quatro repetiçoses.

\begin{tabular}{|c|c|c|c|c|c|}
\hline $\begin{array}{l}\text { Efeitos } \\
\text { principais }\end{array}$ & $\mathbf{P}$ & $k$ & $\mathrm{Ca}$ & $\mathrm{Mg}$ & $\mathbf{S}$ \\
\hline
\end{tabular}

CULTIVAR

$\begin{array}{lcccccccc}\text { Crioula } & 0,12 \mathrm{~A} & 1,18 \mathrm{~A} & 1,53 & \mathrm{~B} & 0,36 & \mathrm{~B} & 0,16 \mathrm{~A} \\ \text { Moapa } & 0,12 \mathrm{~A} & 1,22 \mathrm{~A} & 1,67 \mathrm{~A} & 0,39 \mathrm{~A} & 0,15 \mathrm{~A} \\ \text { Florida } 77 & 0,12 \mathrm{~A} & 1,22 \mathrm{~A} & 1,59 \mathrm{AB} & 0,38 \mathrm{AB} & 0,16 \mathrm{~A} \\ \text { CUF 101 } & 0,12 \mathrm{~A} & 1,17 \mathrm{~A} & 1,58 \mathrm{AB} & 0,38 \mathrm{AB} & 0,16 \mathrm{~A} \\ \text { F } & \mathrm{ns} & \mathrm{ns} & \mathbf{4} & & * & \mathrm{~ns}\end{array}$

Calcário

CALAGEM

(kg/ha)

$\begin{array}{cccccc}0 & 0,13 & 1,20 & 1,51 & 0,35 & 0,16 \\ 950 & 0,12 & 1,17 & 1,65 & 0,37 & 0,17 \\ 1900 & 0,16 & 1,18 & 1,60 & 0,38 & 0,15 \\ 2850 & 0,11 & 1,24 & 1,61 & 0,40 & 0,17 \\ \text { F } & * * & n s & * & * * & n 5 \\ \text { Feg-1in. } & * * & \mathrm{~ns} & \mathrm{~ns} & * * & \mathrm{~ns} \\ \text { Reg-quad. } & * & \mathrm{~ns} & * & \mathrm{~ns} & \mathrm{~ns}\end{array}$

\begin{tabular}{|c|c|c|c|c|c|}
\hline \multirow{2}{*}{$\begin{array}{c}K \\
(k g / h a) \\
o\end{array}$} & \multicolumn{4}{|c|}{ POTASSIO } & \multirow[b]{2}{*}{0.17} \\
\hline & 0,14 & 0,42 & 1,83 & 0,53 & \\
\hline 100 & 0,11 & 1,41 & 1,54 & 0,32 & 0,15 \\
\hline 300 & 0,13 & 1,77 & 1,40 & 0,27 & 0.16 \\
\hline$F$ & $* *$ & ** & $* *$ & $\star *$ & $*$ \\
\hline Reg - 1 in . & $* *$ & ** & $\$$ & $+*$ & ns \\
\hline Reg - quad . & $* *$ & $* *$ & $\neq *$ & ** & * \\
\hline C.V. $(\%)$ & 16,7 & 23,2 & 12,8 & 13,5 & 23,9 \\
\hline
\end{tabular}


Tabela 15. Teores de boro, cobre, ferro, manganes e zinco na parte aérea no primeiro corte (70 dias apos o plantiol, em função dos cultivares, dos niveis de calagen e potássio. Médias de quatro repetiçชes.

\begin{tabular}{|c|c|c|c|c|c|c|c|c|}
\hline \multirow{2}{*}{$\begin{array}{l}\text { Efeitos } \\
\text { principais }\end{array}$} & \multicolumn{2}{|l|}{$\mathbf{B}$} & Cu & $\begin{array}{l}\mathrm{Fe} \\
\mathrm{mg} / \mathrm{kg}\end{array}$ & \multicolumn{2}{|l|}{ Mn } & \multicolumn{2}{|l|}{$\mathbf{Z n}$} \\
\hline & & & \multicolumn{2}{|c|}{ CULT IVAR } & & & & \\
\hline Crioula & $\mathbf{5 5}$ & $A$ & $23 A$ & $130 \mathrm{~A}$ & 83 & $\mathbf{B}$ & 41 & $A$ \\
\hline Moapa & 46 & $\mathbf{B}$ & $21 \mathrm{AB}$ & $125 \mathrm{~A}$ & 93 & $A$ & 38 & $\mathrm{AB}$ \\
\hline Florida 77 & 47 & $\mathbf{B}$ & $20 \mathrm{AB}$ & $119 \mathrm{~A}$ & 80 & $\mathbf{B}$ & 41 & $A$ \\
\hline CUF 101 & 43 & $\mathbf{B}$ & $20 \quad B$ & $124 \mathrm{~A}$ & 80 & B & 36 & $\mathbf{E}$ \\
\hline$F$ & $* *$ & & * & ne & $*$ & & $\$ 1$ & \\
\hline
\end{tabular}

Calcário

( kg/ha)

0

950

1900

2850

$F$

Reg - 1 in.

Reg - quad.
CALAGEM

20

123

107

44

21

133

87

41

46

21

115

76

37

50

22

127

66

33

ns

*

**

t*

**

ns

ns

***

**

ns

**

ns

\begin{tabular}{|c|c|c|c|c|c|}
\hline \multirow{2}{*}{$\begin{array}{c}K \\
(\mathrm{~kg} / \mathrm{ha}) \\
0\end{array}$} & \multicolumn{5}{|c|}{ POTASSIO } \\
\hline & 48 & 21 & 125 & 81 & 34 \\
\hline 100 & 49 & 21 & 123 & 82 & 40 \\
\hline 300 & 45 & 21 & 125 & 89 & 42 \\
\hline$F$ & * & ns & ns & $+\%$ & $* *$ \\
\hline Reg.lin. & ** & ns & ns & $* *$ & $* *$ \\
\hline Reg - quad . & ns & ns & ns & ns & $* *$ \\
\hline C.V. (\%) & 19,5 & 21,6 & 22,4 & 12,6 & 19,3 \\
\hline
\end{tabular}


Tabela 16. Teores de boro, cobre, ferro, manganes e zinco na parte aérea no segundo corte (104-111 dias após o plantio), en funçăo dos cultivares, dos niveis de calagem e de potássio. Médias de quatro repetiçōes.

\begin{tabular}{|c|c|c|c|c|c|}
\hline $\begin{array}{l}\text { Efeitos } \\
\text { principais }\end{array}$ & $\mathbf{B}$ & Cu & $\mathrm{Fe}$ & Mn & $Z_{n}$ \\
\hline & & \multicolumn{4}{|c|}{ CULT IVAR } \\
\hline Crioula & $48 A$ & $38 \mathrm{~A}$ & $432 A$ & $73 \quad \mathrm{BC}$ & $51 \mathrm{~A}$ \\
\hline Moapa & $40 \quad B$ & $38 A$ & $426 A$ & $81 \mathrm{~A}$ & $48 \mathrm{AB}$ \\
\hline Florida 77 & 39 & $37 A$ & $424 A$ & $76 \mathrm{AB}$ & $47 \mathrm{AB}$ \\
\hline CUF 101 & $37 \quad B$ & $38 \mathrm{~A}$ & $392 A$ & 68 & $43 \quad B$ \\
\hline$F$ & $* *$ & ns & ns & $\star *$ & $* *$ \\
\hline
\end{tabular}

\section{Calcário ( $\mathrm{kg} / \mathrm{ha}$ )}

$$
0
$$

950

1900

2850

$F$

Reg 1 in.

Feg - quad.

\section{CALAGEM}

37

38

38

38

ns

ns

ns
469

417

394

395
97

$7 \mathrm{e}$

67

57

\section{**}

1*

**

ns

\section{**}

ns
46

48

47

47

n5

ns

ns

\begin{tabular}{|c|c|c|c|c|c|}
\hline \multirow{2}{*}{$\begin{array}{c}k \\
(k g / h a) \\
0\end{array}$} & \multicolumn{5}{|c|}{ POTASSSID } \\
\hline & 42 & 40 & 430 & 71 & 44 \\
\hline 100 & 40 & 37 & 401 & 73 & 48 \\
\hline 300 & 41 & 35 & 425 & 79 & 49 \\
\hline$F$ & ns & $* *$ & $\mathbf{n s}$ & $* *$ & $*$ \\
\hline Feg - 1 in. & ns & $* *$ & $\mathbf{n s}$ & $* *$ & $* *$ \\
\hline Reg - quad. & ns & ns & ns & ns & $*$ \\
\hline$c . v .(\%)$ & 18,7 & 19,6 & 28,1 & 16,4 & 15,2 \\
\hline
\end{tabular}


Tabela 17. Equaçరిes de regressão obtidas entre teores de alguns macronutrientes e micronutrientes no material do primeiro corte da alfafa, para os niveis de calcário testados $10 ; 950: 1.900$ a 2.850 $\mathrm{kg} / \mathrm{ha}) \mathrm{e}$ seus respectivos coeficientes de determinação $\left(R^{2}\right)$.

Variável estudada

Equaçăo de regressão ${ }^{a} \quad R^{2}$

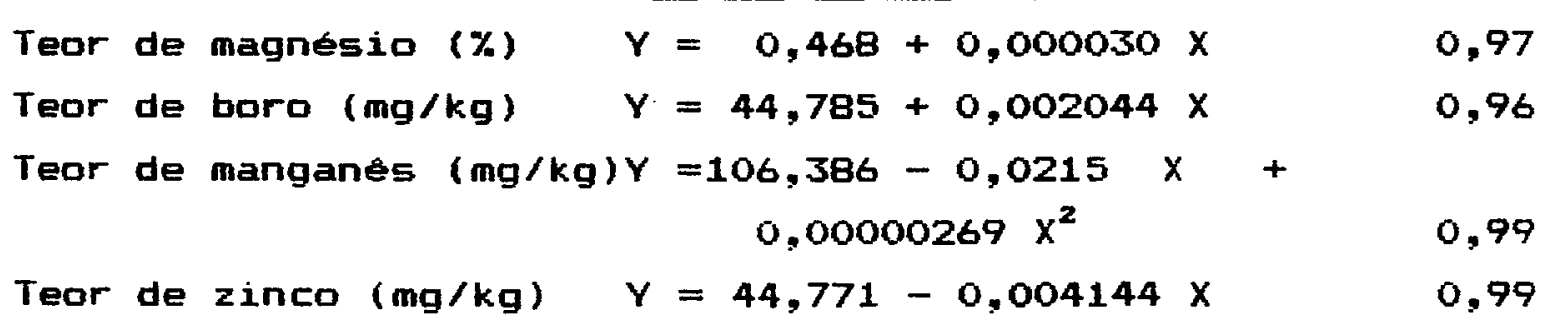

a. $Y$ é o valor para a variável estudada enquanto $X$ a dose de calcário aplicado, dentro dos 1 imites testados. 
Tabela 19. Equaçסes de regressăo obtidas entre teores de alguns macronutrientes $e$ micronutrientes no material do primeiro corte da alfafa, para os níveis de potássio testados $(0 ; 100$ e $300 \mathrm{~kg} / \mathrm{ha})$ e seus respectivos coeficientes de determinação $\left(R^{2}\right)$

\begin{tabular}{|c|c|c|c|c|}
\hline Variável & estudada & Equa & căo de regressă ${ }^{a}$ & $\mathbf{R}^{2}$ \\
\hline Teor de & fosforo $(\%)$ & $Y=$ & $\begin{array}{l}0,1317-0,000202 x+ \\
0,0000004 x^{2}\end{array}$ & 0.99 \\
\hline Teor de & potássio $(\%)$ & $\checkmark=$ & $\begin{array}{l}0,6042+0,01431 \times- \\
0,0000247 x^{2}\end{array}$ & 0.99 \\
\hline Teor de & cálcio (\%) & $Y=$ & $2,745-0,000962 x$ & 0,97 \\
\hline Teor de & magnésio $(\%)$ & $Y=$ & $\begin{array}{l}0,650-0,00248 x+ \\
0,0000044 x^{2}\end{array}$ & 0,99 \\
\hline Teor de & enxofre (\%) & $Y=$ & $0,141-0,000060 x$ & 0,70 \\
\hline Teor de & boro (mg/kg) & $\mathrm{Y}=$ & $49,103+0,0105 x$ & 0,70 \\
\hline Teor de & manganes ( $\mathrm{mg} / \mathrm{kg})$ & $Y=$ & $80,689+0,0264 x$ & 0,99 \\
\hline Teor de & zinco (mg/kg) & $\mathbf{Y}=$ & $\begin{array}{l}34,187+0,074 \times- \\
0,0154 x^{2}\end{array}$ & 0,99 \\
\hline
\end{tabular}

a. Y é o valor para a variável estudada enquanto $x$ a a dose de potássio aplicado, dentro dos limites testados. 
Tabela 19. Equaçôes de regressão obtidas entre teores de alguns macronutrientes $e$ micronutrientes no material do segundo corte da alfafa, para os niveis de calcário testados $10 ; 950 ; 1.900$ a 2.850 $\mathrm{kg} / \mathrm{hal}$ e seus respectivos coeficientes de determinação $\left(R^{2}\right)$.

Teor de fósforo (\%)

$$
\begin{gathered}
Y=0,129-0,000015 x+ \\
0,0000000035 x^{2} \quad 0,99
\end{gathered}
$$

Tear de cálcio (\%)

$$
Y=1,523+0,000127 \times-
$$

$$
0,000000036 x^{2} \quad 0,72
$$

Teor de magnésio ( $\%$

$$
Y=0,345+0,0000177 \times \quad 0,94
$$

Tear de ferro ( $\mathrm{mg} / \mathrm{kg})$

$Y=455,08-0,02554 x$

0,78

Teor de manganes ( $\mathrm{mg} / \mathrm{kg}$ )

$Y=96,226-0,02063 x+$

$$
0,00000236 x^{2}
$$

a. Y é a valor para a variável estudada enquanto $X$ a dose de calcário aplicado, dentro dos limites testados. 
Tabela 20. Equaçóses de regressão obtidas entre teores de alguns macronutrientes e micronutrientes no material do segundo corte da alfafa, para os niveis de potássio testados $(0 ; 100$ e $300 \mathrm{~kg} / \mathrm{ha})$ e seus respectivas coeficientes de determinação $\left(R^{2}\right)$.

Variável estudada Equação de regressão ${ }^{a}$ $R^{2}$

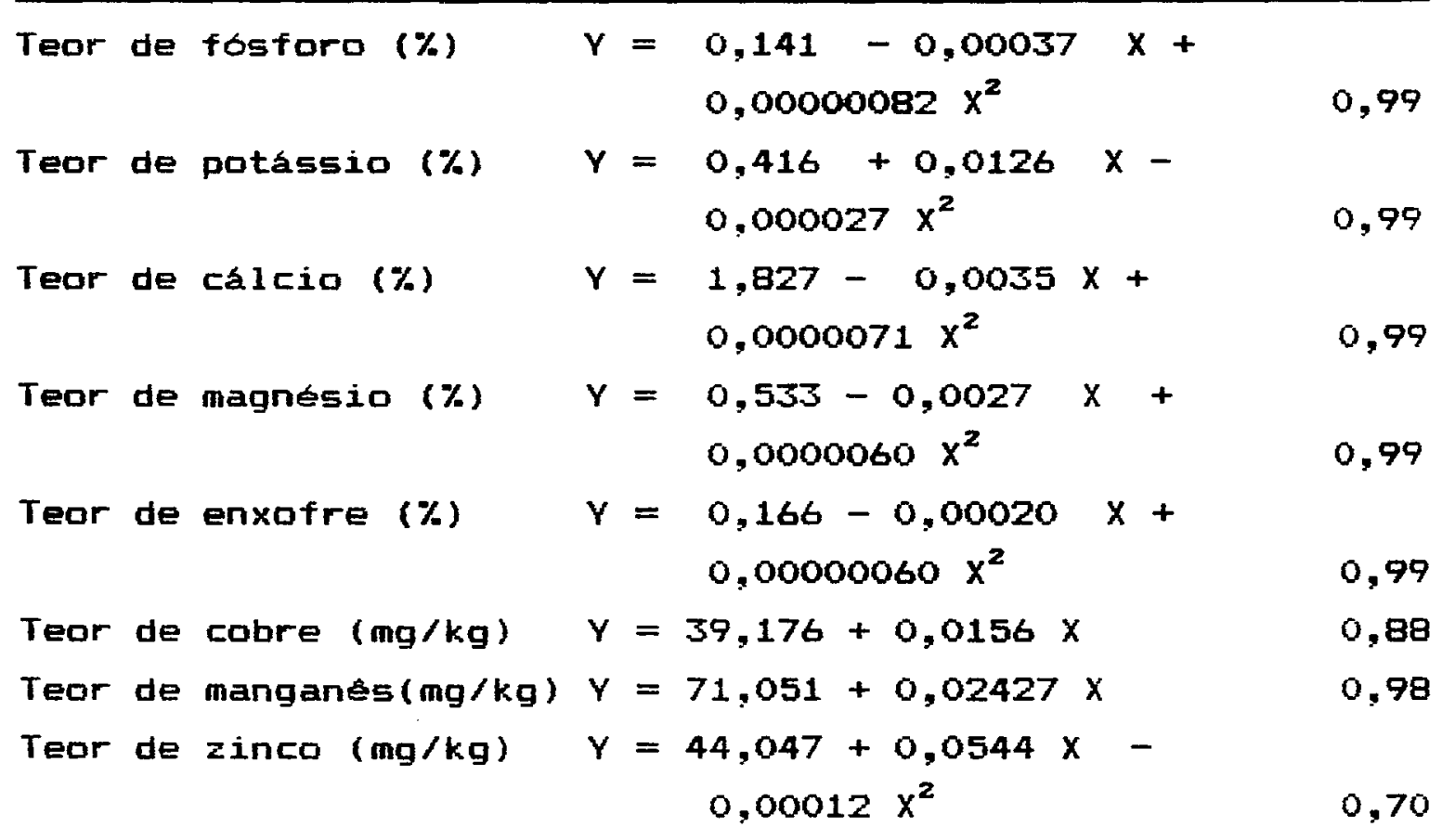

a. Y e valor para a variável estudada enquanto $X$ é a dase de potássio aplicado, dentro dos limites testados. 
No material colhido do segundo corte (Tabela 14) a análise para cultivares revelou diferenças significativas para os teores de cálcio $(P<0,01)$ e os teores de magnesio $(P<0,05)$. O cultivar Moapa apresentou valores superiores ao cultivar Crioula, para as duas variáveis, não diferindo dos cultivares florida 77 e CUF 101. Para fósforo: potássio e enxofre não foram detectadas diferenças significativas $(P>0,05)$ entre cultivares neste corte.

No que se refere aos micronutrientes (boro, cobre, manganes e zinco) cabe salientar que, para os cultivares testados houve diferença significativa (P $<0,01$ ) para os teores de boro, manganes e zinco encontrados no material colhido da parte aérea, no primeiro e segundo cortes (Tabelas 15 e 16). O cultivar Crioula, apresentou teor de boro superior aos demais cultivares (valores de 55 e $48 \mathrm{mg} / \mathrm{kg}$ no primeiro e segundo corte, respectivamente nesse cultivar). Dentre os micronutrientes, o boro é normalmente o mais exigido pela alfafa, sendo por esta razão usualmente feitas aplicaçชes para o estabelecimento dessa cultura (NUERNBERG, 1986). A alfafa parece ser particularmente suscetivel a deficiencia de boro e muitos trabalnos ten tentado determinar o nivel adequado desse elemento. Vários deles já estimaram, teores de 7 a $23 \mathrm{mg} / \mathrm{kg}$ como a faixa para deficiencia desse nutriente na alfafa (HANSON, 1972). No presente trabalho os teores encontrados nos cultivares excede a esses niveis 
apontados para a deficiencia desse micronutriente.

Os teores de zinco no material colhido do primeiro corte, ficaram entre 36 e $41 \mathrm{mg} / \mathrm{kg}$, tendo os cultivares Crioula e Florida 77 concentraçбes superiores significativamente $(P<0,01$ ) as do cultivar CUF 101 (Tabela 15). Os teores de zinco encontrados no material do segundo corte variaram entre 43 e $51 \mathrm{mg} / \mathrm{kg}$, sendo que o cultivar Crioula apresentou o teor máximo encontrado, diferindo significativamente $(P<0,01)$ do cultivar CUF 101 (Tabela 16). Em estudos conduzidos em casa de vegetação, a aplicação de zinco reduzill a absorção de boro em solo com baixa disponibilidade de boro, possivelmente interferindo no transporte desse nutriente pela planta (HANSON, 1988). Isso não ocorreu neste trabalho, onde tanto a teor de bora camo o de zinco foran superiores aos teores reconhecidos como deficientes na alfafa.

A concentração adequada de manganes na parte aérea da planta situa-se entre 25 a $200 \mathrm{mg} / \mathrm{kg}$, segundo HANSON (1972). No presente trabaliho, encontraram-se teores de manganes variando de 80 a $93 \mathrm{mg} / \mathrm{kg}$ ede 68 a $81 \mathrm{mg} / \mathrm{kg}$, no primeiro corte e segundo corte, respectivamente (Tabela 15 e 16). Dcorreram diferencas significativas $(P<0,01)$ entre os cultivares sendo que o cultivar que se destacou pelas maiores concentraçôes $\bullet$ o Moapa no primeiro e no segundo corte, mas que não revelou interferéncia na absorção do cálcio. FRIED \& FEECH (1946) encontraram boa indicação de que o manganes, que 
E facilmente absorvido pela planta, pode impedir a absorçã do cálcio.

Fesultados conflitantes encontrados na

literatura quanto à concentração normal de manganess da alfafa durante o crescimento, parecem resultar do fato de que a absorção de manganes é influenciada consideravelmente por alguns fatores do solo, particularmente pelo $\mathrm{pH}$ e drenagem. Isso será discutido posteriormente.

As espécies de plantas diferem bastante quanto ao seu conteúdo de cobre. Essa diferença é influenciada pela disponibilidade desse elemento no solo e sabe-se que deficiências sãa significativas para alfafa. ANDREW \& THORNE (1962) consideraram a concentraçăo de $5 \mathrm{mg} / \mathrm{kg}$ satisfatória, enquanto abaixo de $4 \mathrm{mg} / \mathrm{kg}$ apontaram deficiéncia desse micronutriente. Neste trabalho encontraram-se teores de cobre que variaram de 20 a $23 \mathrm{mg} / \mathrm{kg}$ no primeiro corte (Tabela 15) com diferença significativa ( $<<0.05$ ) entre os cultivares Crioula (23 mg/kg) e CUF 101 (20 $\mathrm{mg} / \mathrm{kg})=$ No segundo corte não houve diferença significativa ( $P$ > 0,05 ) entre os cultivares para essa variável, enquanto os teores encontrados foram de 37 e $38 \mathrm{mg} / \mathrm{kg}$ (Tabela 16). Isso concorda com o trabalho de MAIER \& EAfLEY (1965) no qual eles reportaram que o cobre em niveis variando entre 16 e $36 \mathrm{mg} / \mathrm{kg}$ seriam considerados normais.

Ainda em relação ăs cultivares, não houve diferença significativa $(P \quad>0,05)$ quanto aos teores de 
ferro na parte aérea das plantas.

Os resultados obtidos nas análises químicas das amostras da parte aerea da planta para macronutrientes no material do primeiro corte, em funça da calagem e do potássio, são apresentados na Tabela 13, e suas respectivas equaçós de regressão nas Tabelas 17 e 18.

Para os niveis de calcário testados não houve diferença significativa $(P>0,05$ ) para os teores de fóforo, potássio, cálcio e enxofre na planta (Tabela 13), no primeiro corte. Para magnésio o efeito foi linear e sua equação de regressão está na Tabela 17.

Para as doses de potássio aplicadas o efeito foi quadrático para os teores de fósforo, magnésio e potássio na forragem do primeiro corte (Tabela 13). 0 ponto de minimo teor ocorreu com $252 \mathrm{~kg} \mathrm{~K} / \mathrm{ha}$ para fósforo, $282 \mathrm{~kg} \mathrm{K/ha} \mathrm{para}$ magnesij, enquanto $290 \mathrm{~kg} \mathrm{K/ha}$ foi encontrado como ponto cie máximo para a concentração máxima de potássio. As figuras 14, 15 e 16 mostram esses resultados e suas equaços de regressão estão na Tabela 18. Fara os teores de cálcio (Figura 17), e enxofre, em funçăo dos niveis de potássio, os resultados mostraram decréscimo significativo $(P<0,01)$ e linear (Tabela 13), cujas equaçชes de regressăo encontram-se na Tabela 18.

Merece destaque especial o sintoma visual de deficiencia de potássio na planta, nos tratamentos que não receberam adubação potássica, ocorrendo redução do 
crescimento seguido de clorose e necrose das fol has.

Interaçzes importantes com reflexos na produçă sã observadas principalmente entre potássio, cálcio e magnésio. As reaçóes das plantas ao potassio são mais acentuadas na presença de calcário, confirmanda a importáncia de se considerar o equilibrio de bases trocáveis no critério de recomendação de adubação potássica (VAMADA, 1986).

A adubação potássica interferiu negativamente nos teores de cálcio encontrados na parte aérea da planta (Figura 16), no primeiro corte. Em função das doses de calcário empregadas não se detectou significância ( $>$ > 0,05 ) para os teores de potássio, em ambos os cortes (Tabela 13 e 14).

0 conhecimento dos efeitos de outros 1 ons na nutriçăo potássica é importante, não só para se maximizar a eficiéncia do uso de potássio, mas também para se saber como os niveis de outros íns vão alterar as recomendaçôs feitas aos agricultores sobre o emprego de adubo potássico.

As concentraçôes de potássio, en função dos niveis de calcário, encontradas no material colhido ficaram entre 1,17 a $1,20 \%$ e săo considerados normais. As forragens removidas do campo podem conter entre 1 a $3 \%$ de potássio na matéria seca, segundo HANSON (1972) e YAMADA (1986). 


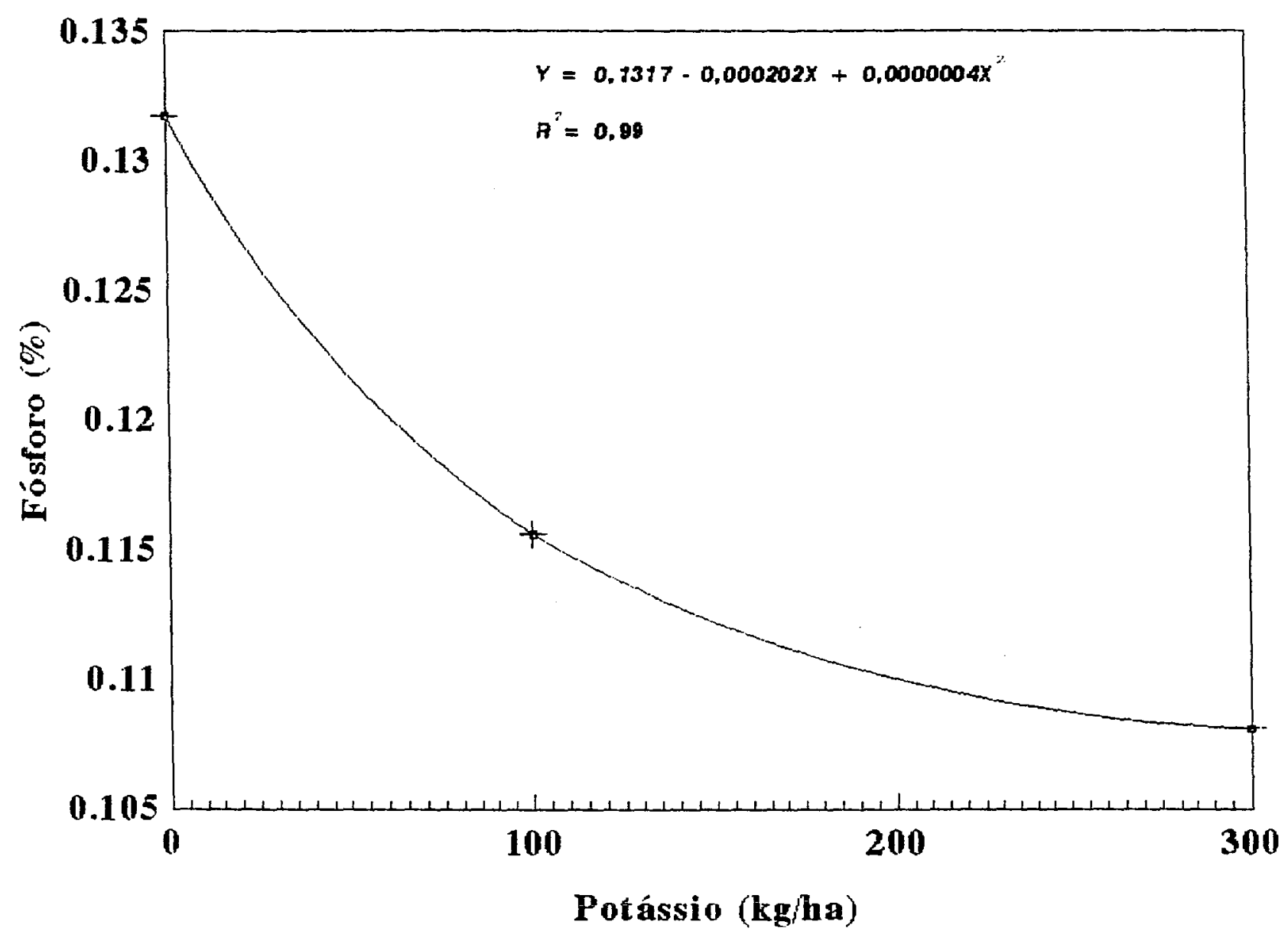

Figura 14 - Forcentagem de fósforo na parte aerea da alfafa, no material colhido no primeiro corte, em função do potássio aplicado. 


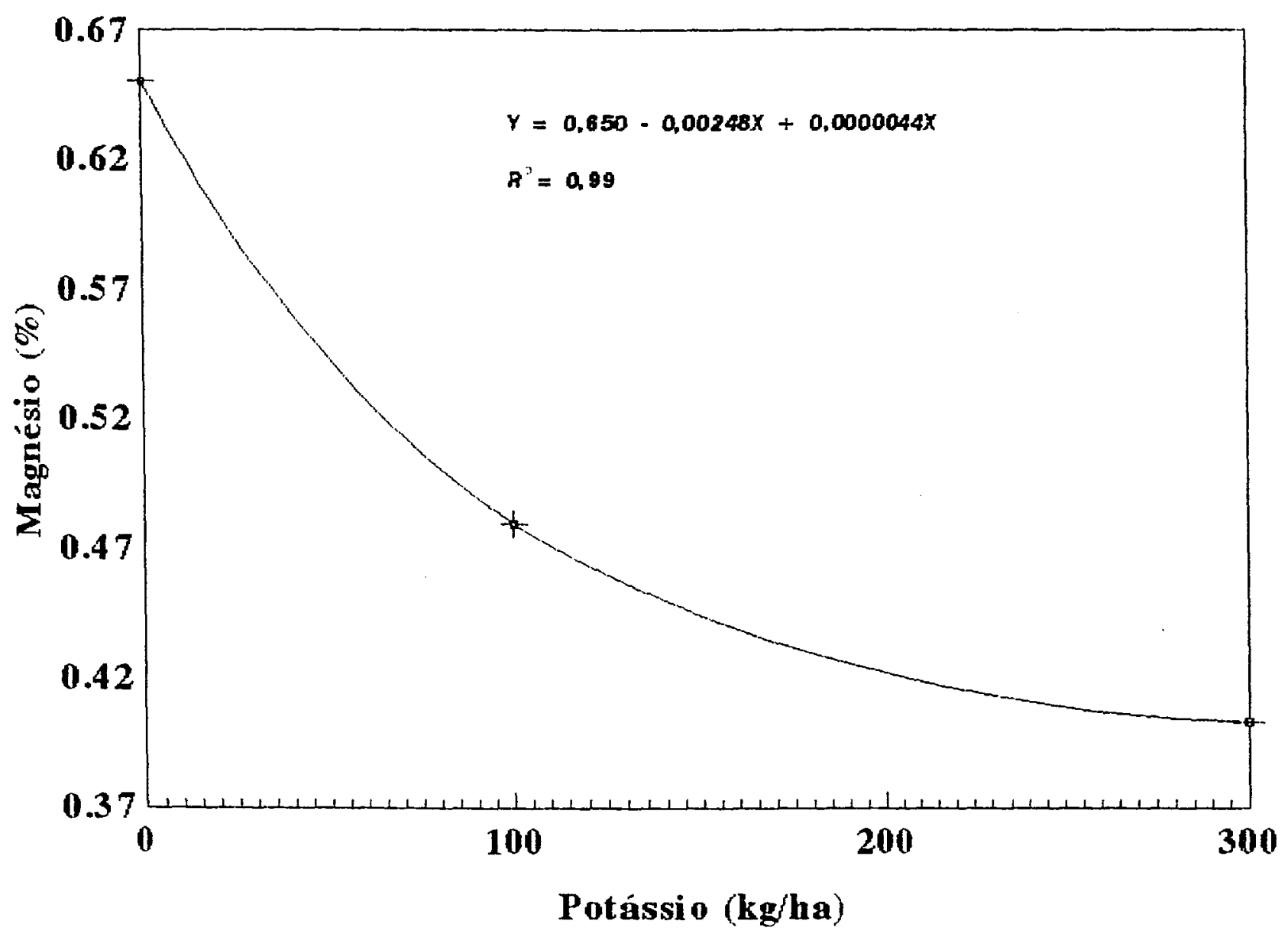

Figura 15 - Porcentagen de magnésio na parte aerea da alfafa, no material colhido no primeiro corte, en função do potássio aplicado. 


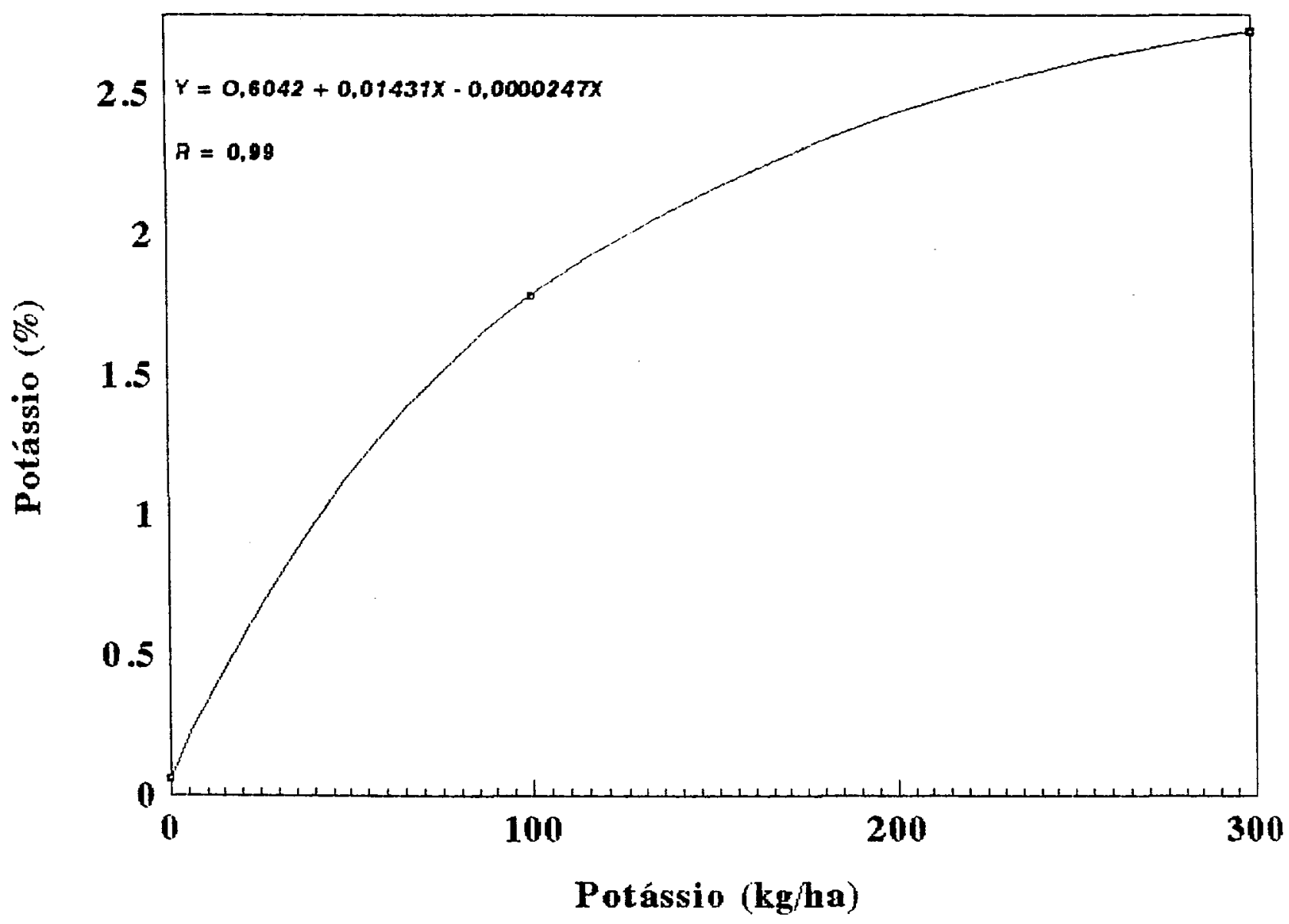

Figura 16 - Porcentagem de potássio na parte área da alfafa, no materiai colhido no primeiro corte, em funçăo do potássio aplicado. 


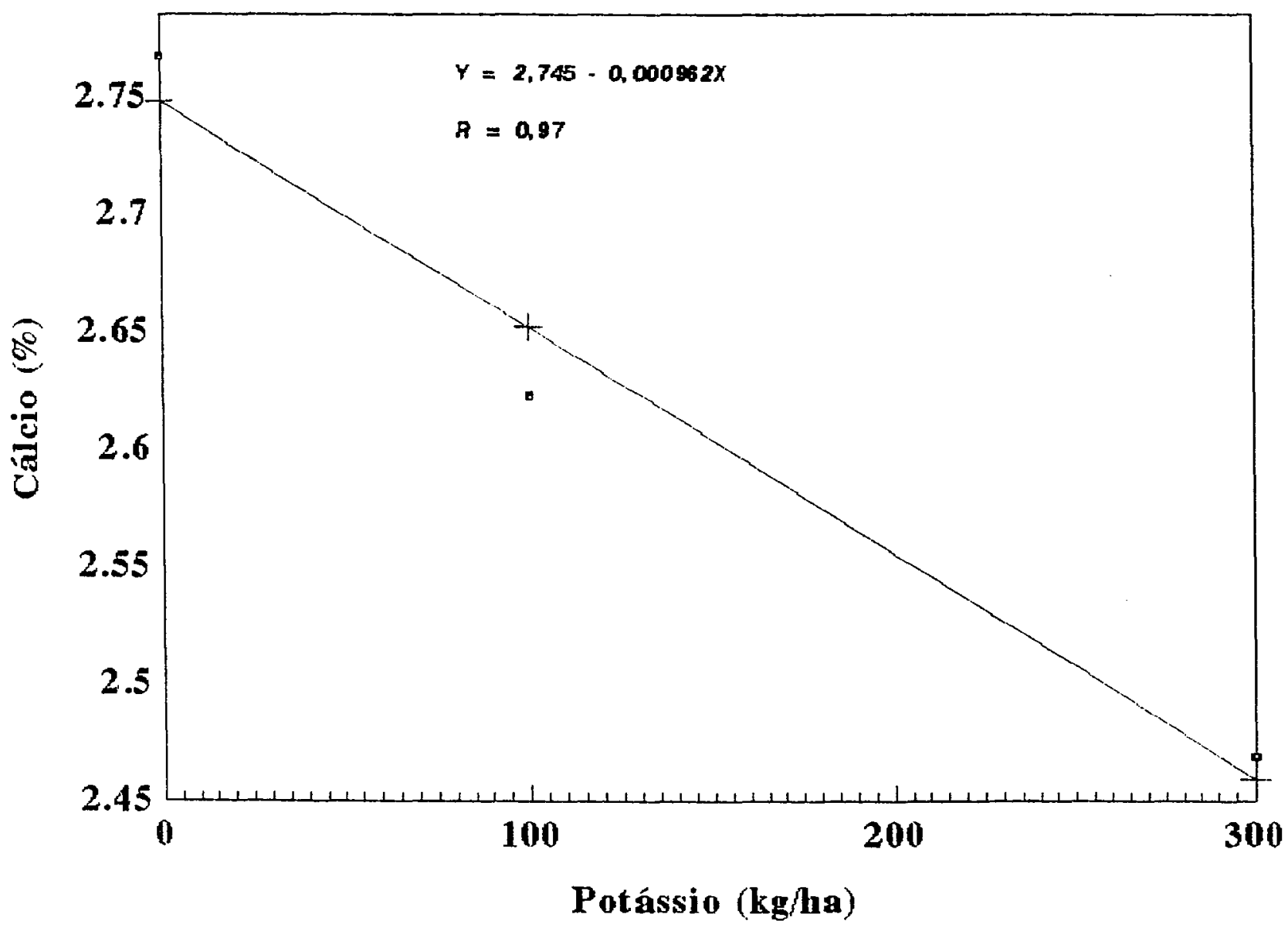

Figura 17 - Porcentagem de cálcio na parte aerea da alfafa, no material colhido no primeiro corte, en função do potássio aplicado. 
Entre os qutros macronutrientes, os teores de fósforo e cálcio tiveram variaçชes significativas (P< 0,05 ) e quadráticas (Tabela 14 e Figuras 18 e 19) no segundo corte, em função da calagem e as respectivas equaçชes de regressăo constam na Tabela 19. Fara o fósforo, o efeito quadratico revelou um ponto de mínimo para a dose de calcário de 2273 kg/ha. Para os teores de cálcio o efeito quadrático permitiu obter a ponto de máximo com a dose de $1764 \mathrm{~kg} / \mathrm{ha}$ (Tabela 19).

Os teores de enxofre encontrados no material colhido no segundo corte, não apresentaram significancia para os niveis de calagem empregados (Tabela 14). Quanto aos teores de magnésio o efeito foi linear com significancia a 1\%, tal como ocorreu no primeiro corte.

Para os niveis de potássio aplicados no segundo corte (Tabela 14), os resultados das análises para os teores de fósforo, potássio, cálcio e magnésio revelaram significancias (F $<0,01$ ) e efeitos quadraticos. Na Tabela 20, săo apresentadas as equaçชes de regressão e os coeficientes de determinação. Pode-se constatar que somente para os teores de potássio o efeito quadrático permitiu obter um ponto de máximo em $233 \mathrm{~kg} \mathrm{k} / \mathrm{ha}$ (Figura 20). Para os teores de enxofre o efeito foi significativo $(P<0,05)$ e quadratico (Tabela 20).

Os teores de boro, cobre, ferro, manganes e zinco encontrados na parte aerea da alfafa, no primeiro e 


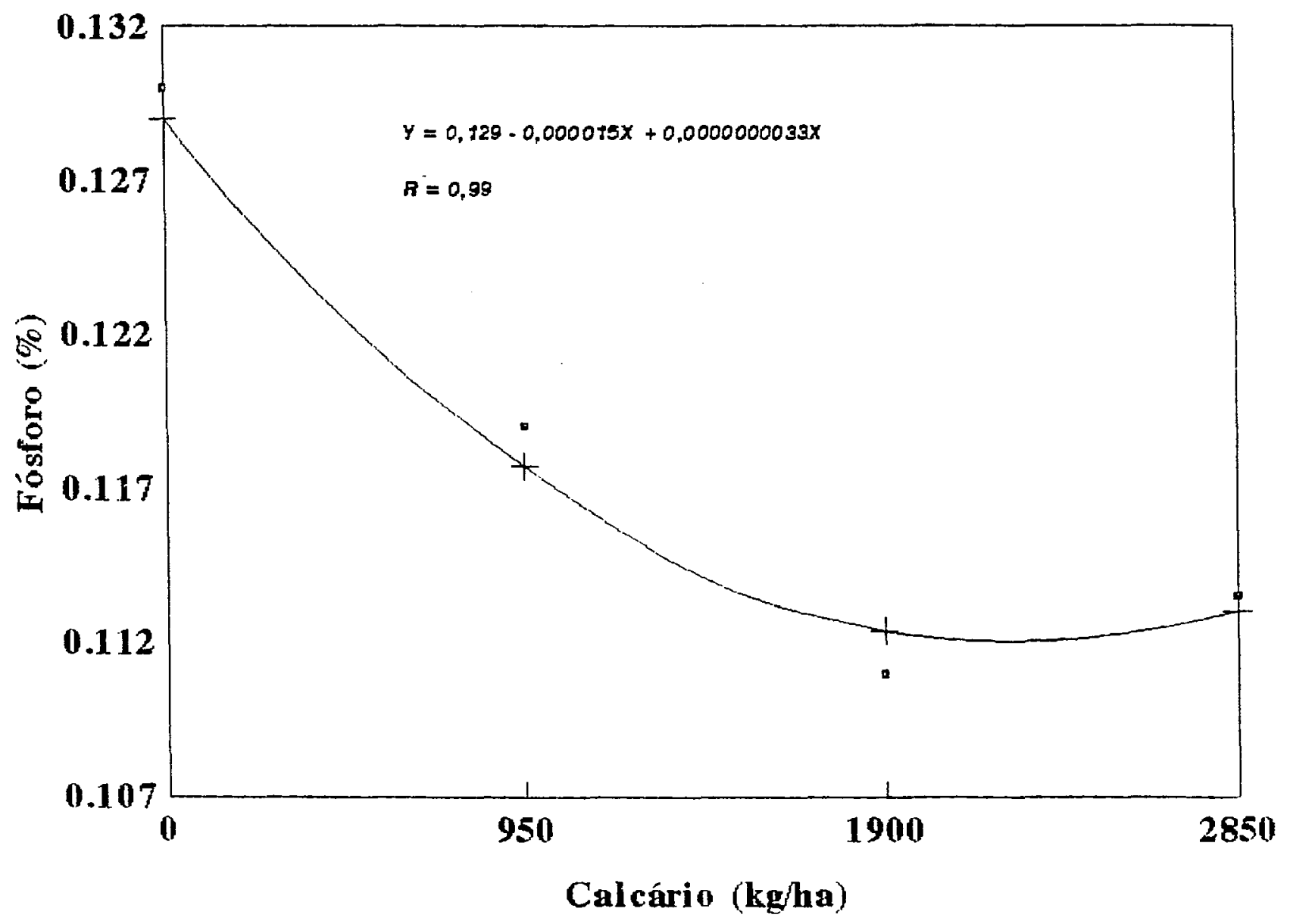

Figura 18 - Porcentagem de fósforo na parte aerea da alfafa no material colhido no segundo corte en função do calcário aplicado. 


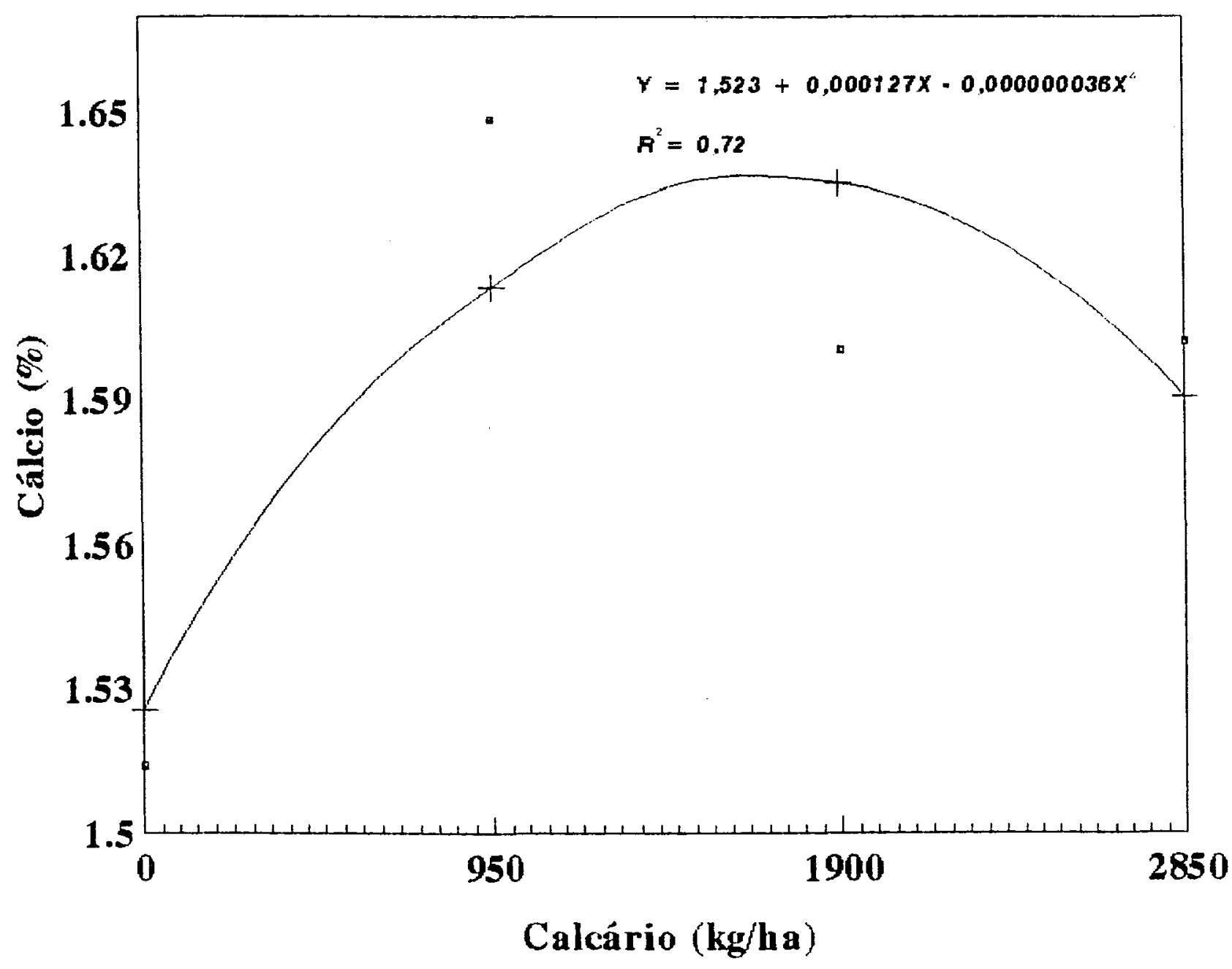

Figura 19 - Porcentagem de cálcio na parte aérea da alfafa no material colhido no segundo corte em função do calcário aplicado. 


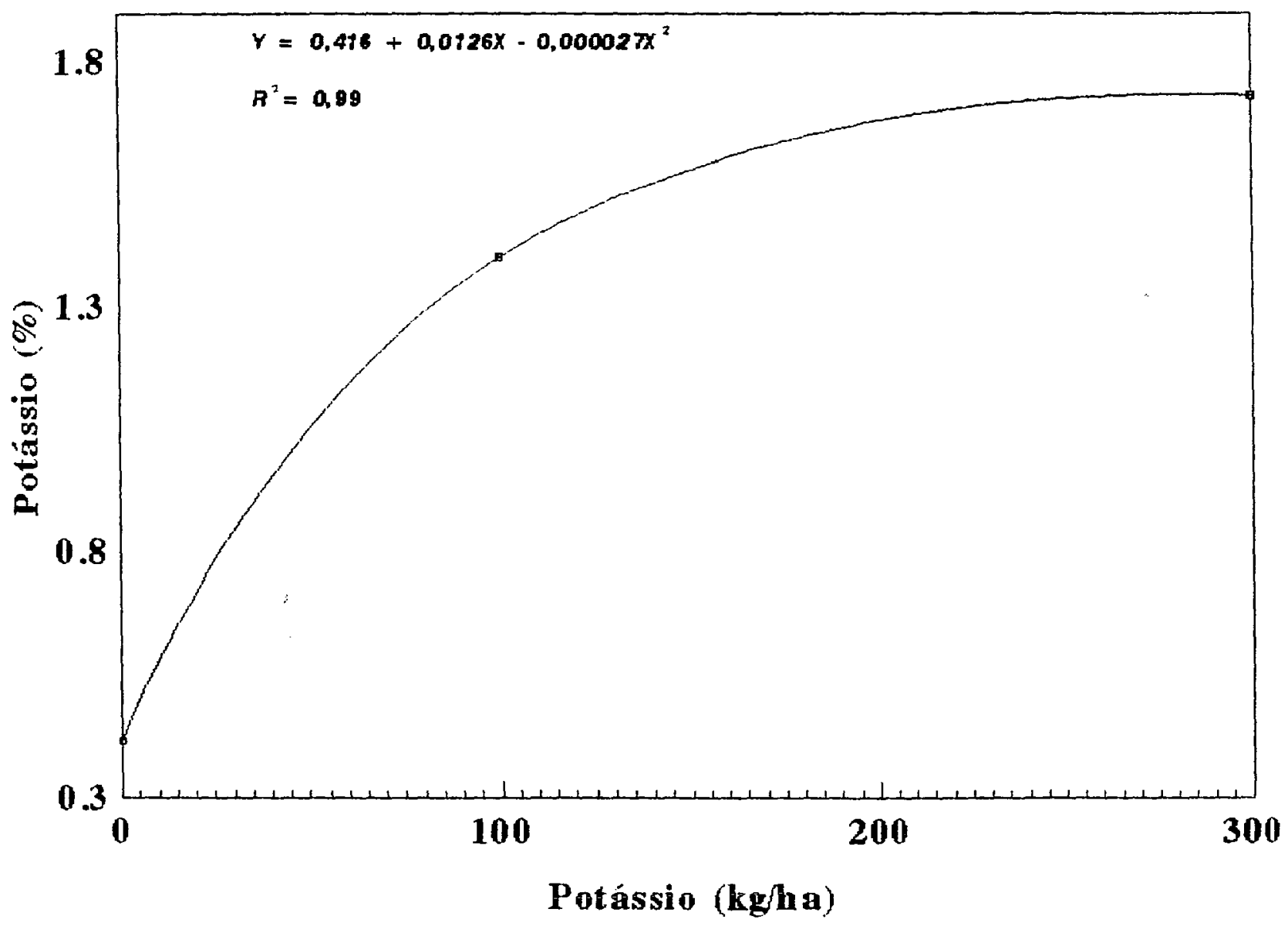

Figura 20 - Forcentagem de potássio na parte aérea da alfafa, no material colhido no segundo corte en função do potássio aplicado. 
segundo corte são apresentados nas Tabelas 15 e 16 . Para as doses de calcário aplicadas, os teores de cobre nao apresentaram significância $(P>0,05)$ no primeiro e segundo corte (Tabela 15 e 16). Tambem năo houve significancia $(P>0,05)$ para os teores de boro $e$ de zinco no material colhida do segundo corte (Tabela 16).

A concentração de boro na parte aérea dessa leguminosa, no primeiro corte (Tabela 15), mostrou acréscimos até o mais alto nivel de calagen testado, o que resultou em efeito linear da calagem (Tabela 17 e Figura 21). A alfafa parece particularmente suscetivel à deficiencia de boro, e esse micronutriente pode ficar indisponivel no solo en função do excesso de calagem, o que resulta na redução de absorção pelas plantas (HANSON, 1972). Isto não ocorreu neste trabalho, uma vez que teores médios encontrados foram de 45,0 a $50,5 \mathrm{mg} / \mathrm{kg}$; valores estes distantes dos valores considerados deficientes ( 7 a $23 \mathrm{mg} / \mathrm{kg}$ ) para alfafa, por HANSON (1972).

A medida que se acrescentou o calcario ao salo, as teores de zinco decresceram linearmente no material colnido no primeiro corte (Tabela 15). Redução na concentração de zinco en consequencia da aplicaçăo de calcário foi relatada por MALAVOLTA (1980).

A calagem diminuiu a disponibilidade de ferro. no segundo crescimento da leguminosa (Tabela 16) e resultou em um efeito linear negativo na planta (Tabela 18). A 
concentração desse nutriente no material do segundo corte fai significativamente $(P<0,05)$ reduzida pelo emprego do corretivo no solo. A absorção de ferro diminuiu quando aumentou a concentração de cálcio e magnésio (entre outros minerais). Na planta em desenvolvimento e na adulta, não se dá praticamente a redistribuiçăo do ferro, e como consequência, a lámina foliar fica clorótica (MALAVQLTA, 1980).

A ausência de calagen e a calagen excessiva podem resultar em toxidez e deficiencia de manganes, respectivamente (MALAVOLTA, 1976). Resultados de pesquisa tem mostrado variaçöes no nivel tóxico para alfafa, podendo este ser alcançado a partir de $175 \mathrm{mg} / \mathrm{kg}$ (OVELLETTE \& DESSUREAUX, 1958) Q $380 \mathrm{mg} / \mathrm{kg}$ (ANDREW \& HEGARTY, 1969). material colhido no primeiro corte (Tabela 15) apresentou: para os niveis de caiagen, teores de manganés variando entre 66,5 e $106,8 \mathrm{mg} / \mathrm{kg}$ e mostrando um efeito quadratico (Figura 22). A alfafa e uma cultura bastante responsiva a calagem: pois como um dos efeitos reduz a disponibilidade de manganes no solo e sua concentraçăo na parte aerea da alfafa a niveis nãa toxicos.

Ds teores de manganes, en função dos niveis de calagem, encontrados no material do segundo corte (Tabela 16 e Figura 23) foram de 56,9 a $96,6 \mathrm{mg} / \mathrm{kg}$ e caracterizou-se por um efeito quadratico (Tabela 19 ) e significativo $(P<0,05$ ). Segundo HANSON (1972), a concentraçăo de manganés normalmente 


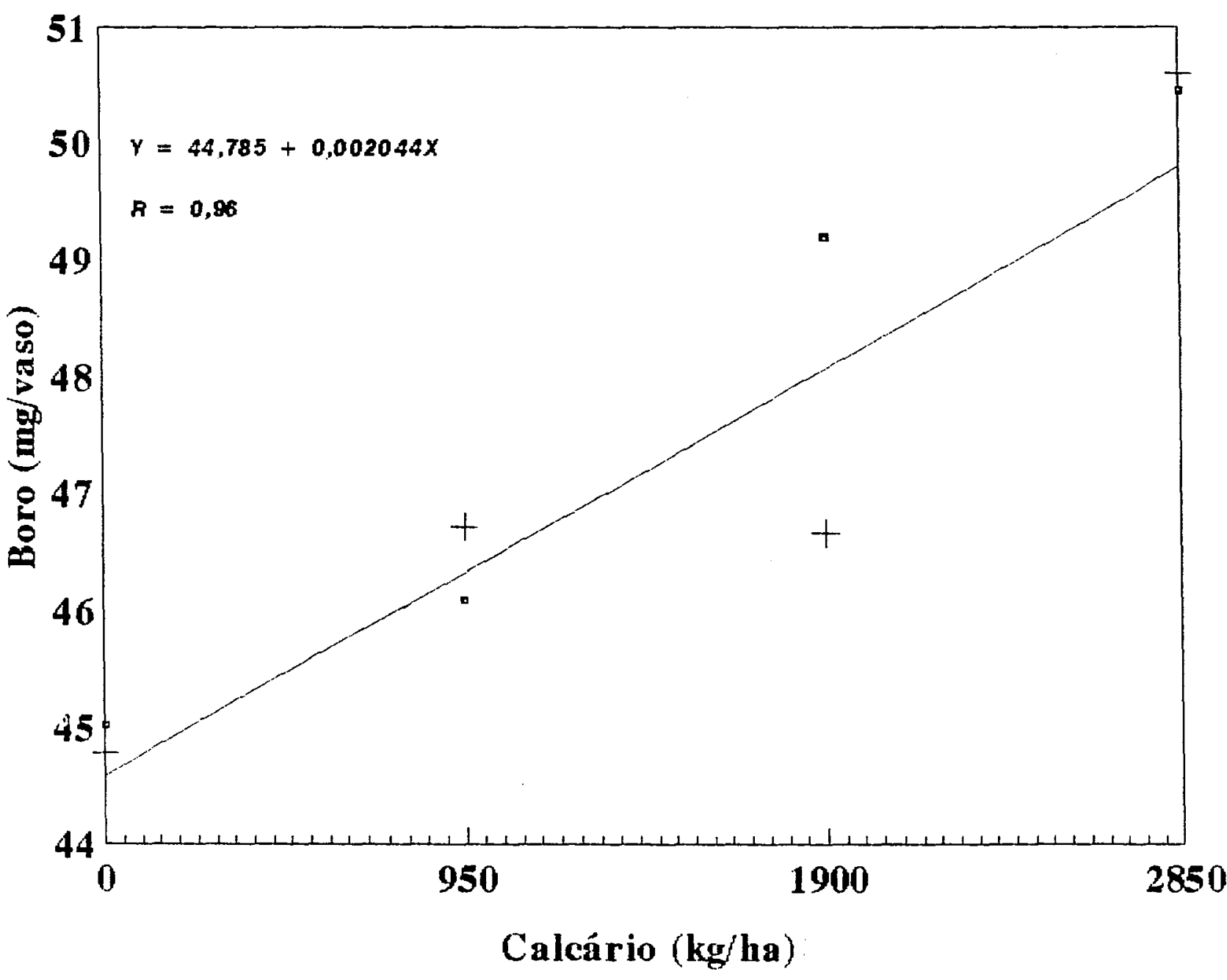

Figura 21 - Teor de boro na parte aerea da alfafa no material colhido no primeiro corte en função do calcário aplicado. 


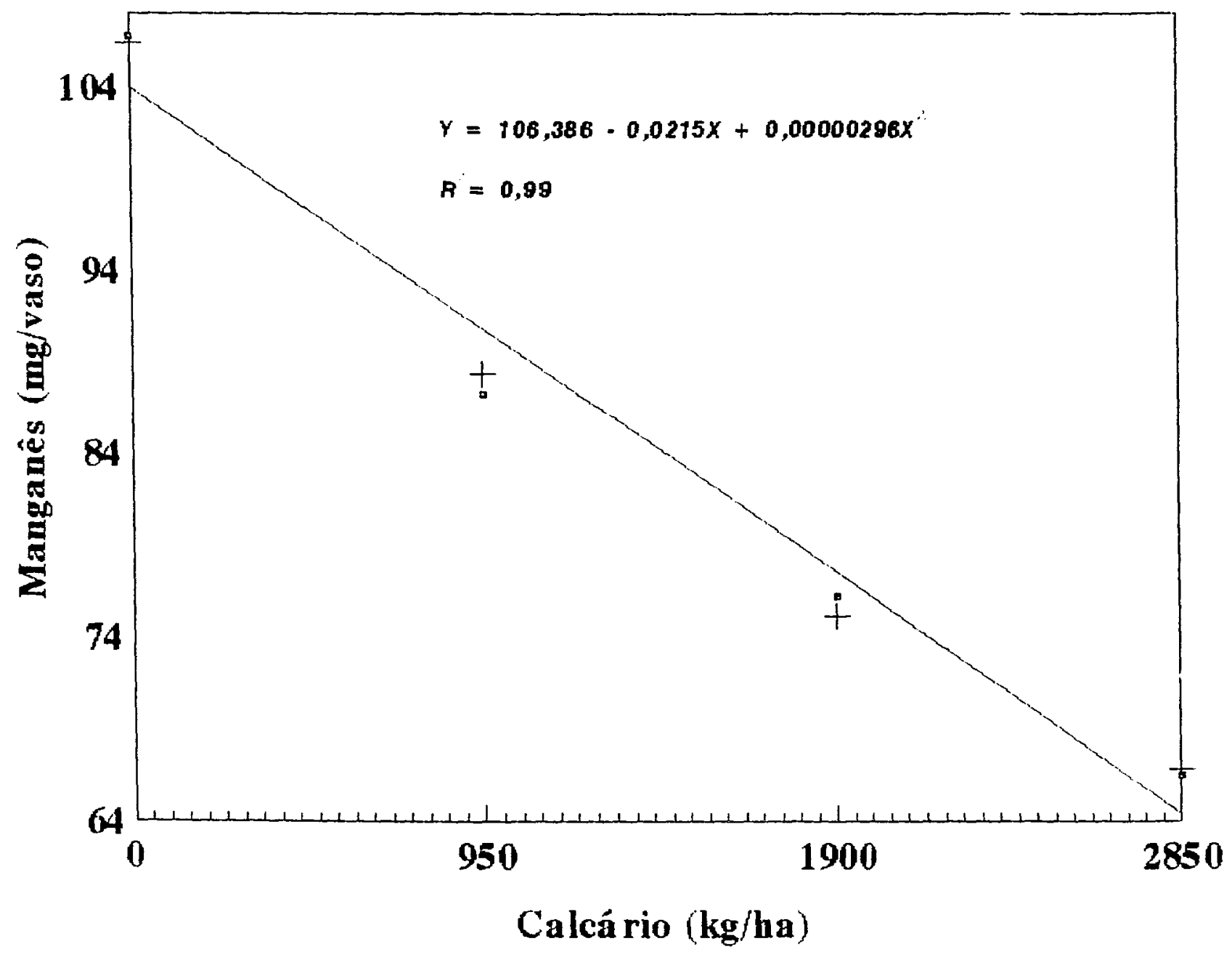

Figura 22 - Teor de manganes na parte aerea da alfafa no material colhido no primeiro corte em função do calcário aplicado. 


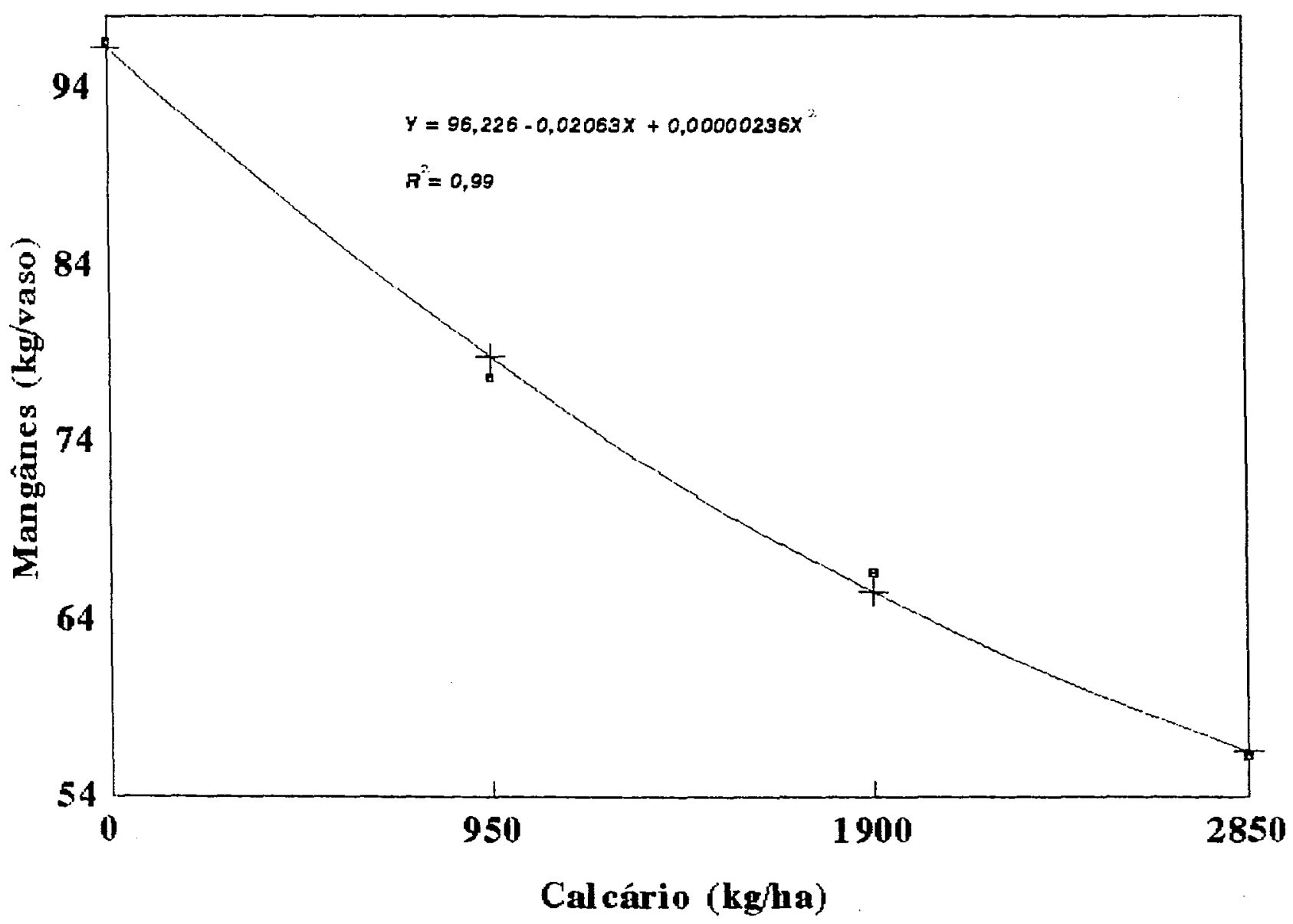

Figura 23 - Teor de manganes na parte aérea da alfafa no material colhido no segundo corte en função do calcário aplicado. 
encontrada na parte aerea da alfafa, fica entre 25 a 200 mg/kg. Trabalhos conflitantes na literatura sobre a concentraçăo adequada desse nutriente na alfafa durante o crescimento, resultam do fato de que a absorção de manganés é consideravelmente influenciada pelos fatores do solo, particularmente o pH e a umidade. As deficiéncias comumente estão associadas aos solos que receberam elevadas quantidades de corretivos.

A aplicação de potássio favoreceu a absorção de manganés, no primeiro e segundo corte (Tabelas 15 e 16 e Figuras 24 e 25), e efeito fai linear para ambos os cortes (Tabela 18 e 20). Isto concorda com os resultados de KORNELIUS (1972) E RANDO (1992).

Ds resultados relativos aos teores de ferro, considerando a aplicaçăo das doses de potássio, encontram-se nas Tabelas 15 e 16, para o primeiro $e$ segundo corte, respectivamente. Esses resultados revelaram a nao significancia na variaçăo daqueles teores em função da adubação potássica.

No primeiro corte confirmou-se o efeito linear e negativo para os teores de boro encontrados, para os niveis de adubaçãa potássica (Tabela 15 e Figura 26). Por ocasião do segundo corte se obteve significancia para esse efeito (Tabela 16).

Houve un incremento 1 inear para os teores de zinco no segundo corte (Tabela 16) e un efeito quadrático no 
primeiro corte (Tabela 15), em função das doses de potássio aplicadas. As equaçớes de regressão encontram-se nas Tabelas 18 e 20 , respectivamente.

No primeiro corte não existiu diferença significativa ( $P>0,05$ ) para os teores de cobre en função da aplicação da adubação potássica (Tabela 15). Verificou-se um efeito linear e negativo para o material colhido no segundo corte (Tabela 16), com sua equação encontranda-se na Tabela 20. 


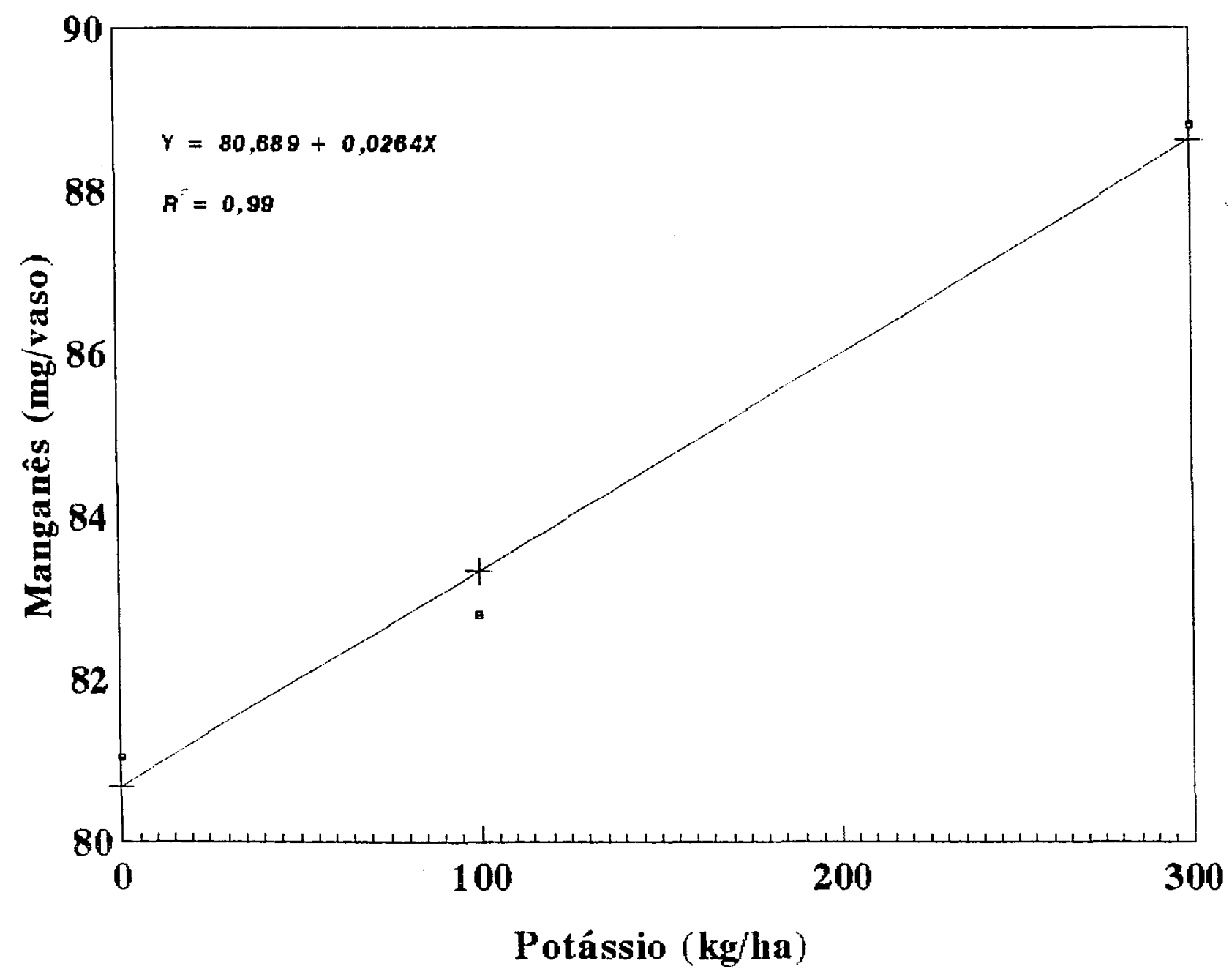

Figura 24 - Teor de manganes na parte ałrea da alfafa no material colhido no primeiro corte em função do potássio aplicado. 


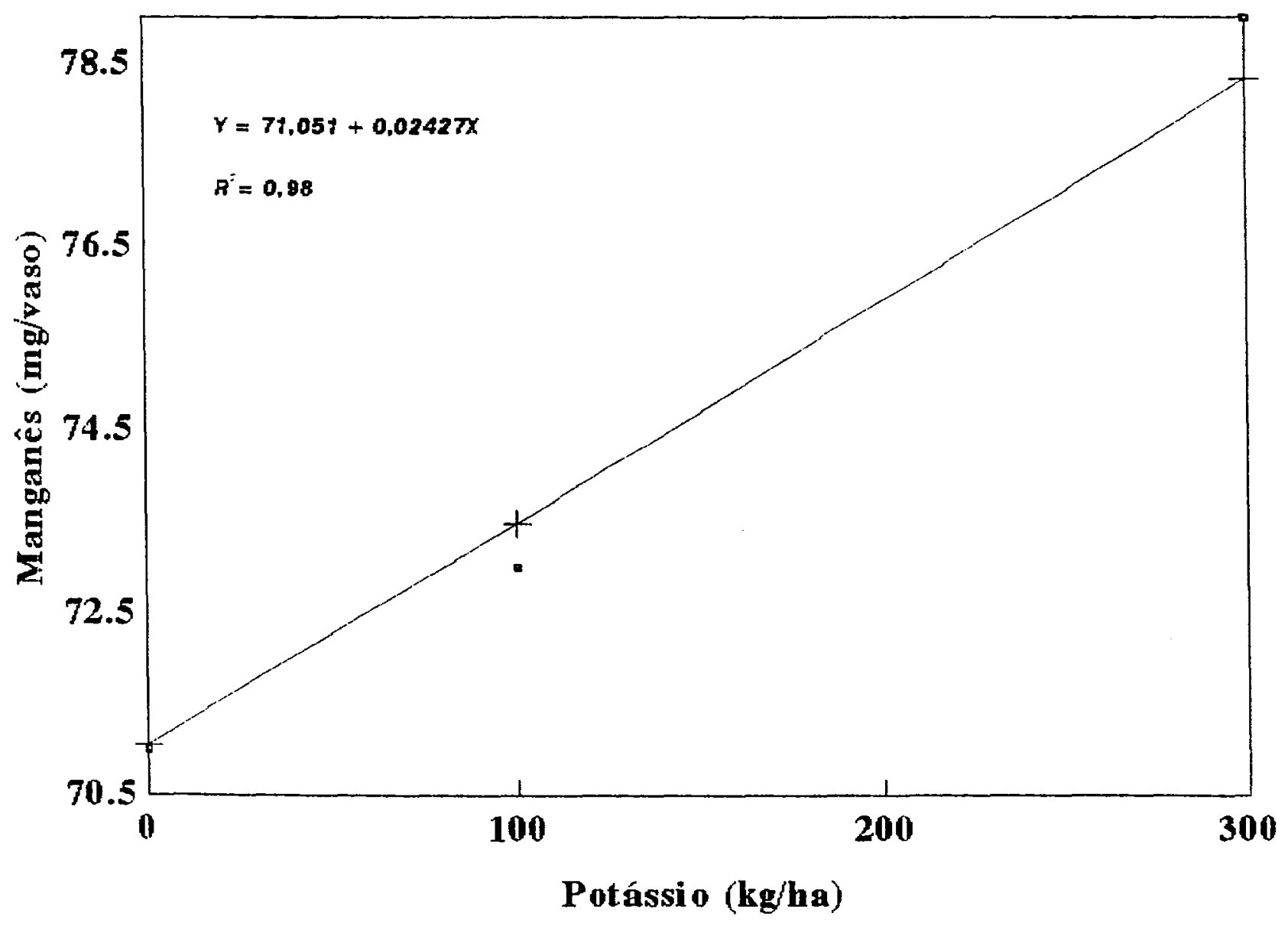

Figura 25 - Teor de manganés na parte aérea da alfafa no material colnido no segundo corte en função do potássio aplicado. 


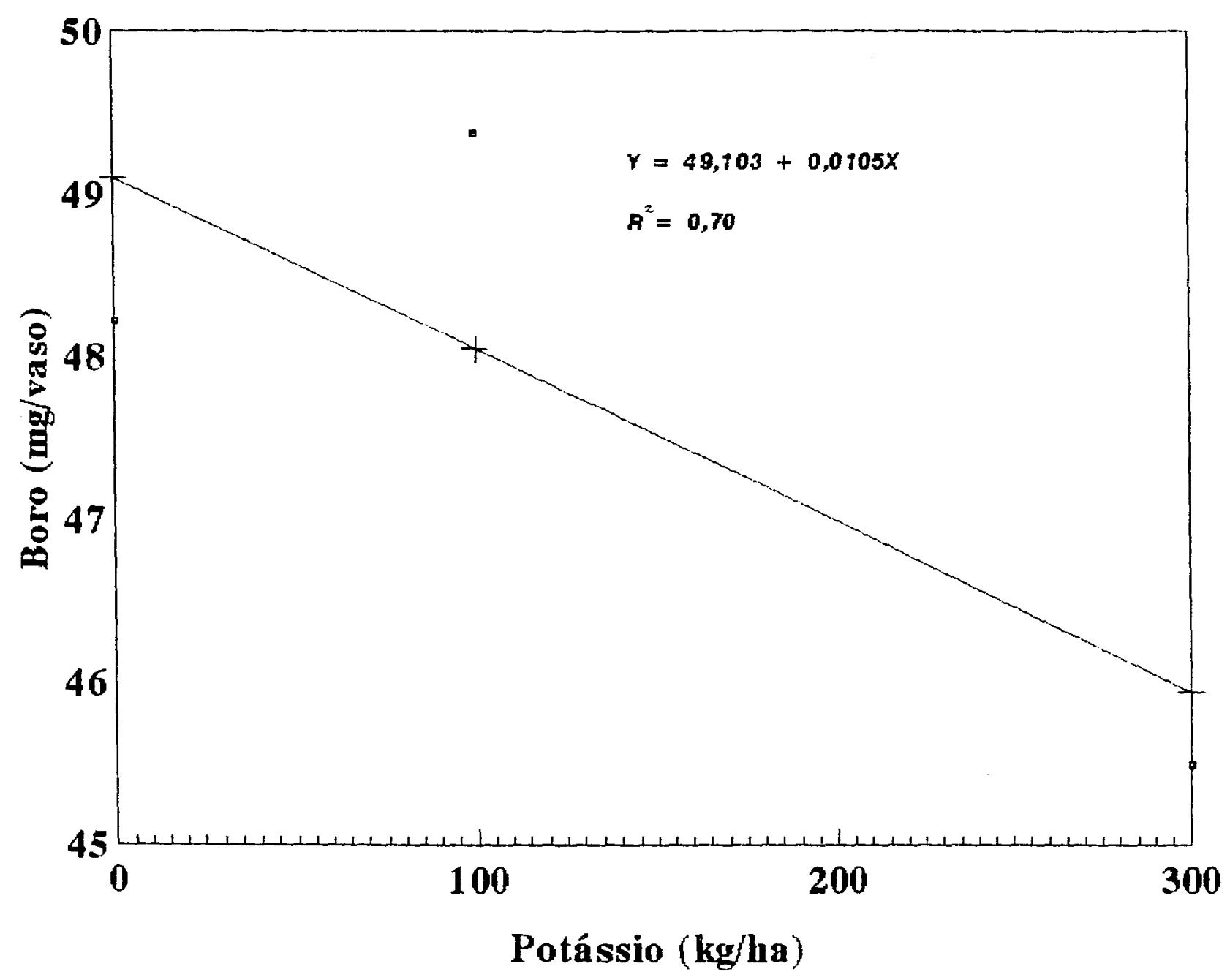

Figura 26 - Teor de boro na parte aerea da alfafa no material colnido no primeiro corte en função do potássio aplicado. 
5. CONCLUSÖES

Com base nos resultados obtidas no presente trabalho pode-se apontar as seguintes conclusoes:

1. Ds cultivares florida 77 e CUF 101, mostraram maior produção de materia seca que os cultivares Crioula e Moapa, no primeiro corte do experimento;

2. D cultivar Florida 77 teve menor produçăo de materia seca de ralzes que os cultivares Crioula, Moapa e CUF 101 ;

3. Os niveis de corretivo de acidez $e$ de cloreto de potássio utilizados propiciaran incrementos significativos na produção de materia seca e na quantidade total de nitrogenio nos cultivares de alfafa;

4. No primeiro crescimento da alfafa não se conseguiu atingir a máxima produção de matéria seca, com as doses de calcário empregadas. Fara máxima produçăo de 
matéria seca (parte aérea e raizes) e quantidade total de nitrogénio da alfafa, a calagem necessária variou de 2.200 a $2.750 \mathrm{~kg} / \mathrm{ha} e$ a porcentagem de saturação por bases do solo no momento do plantio variou de 54,0 a $67,5 \%$;

5. A máxima produção de materia seca (parte aérea e raizes) e quantidade total de nitrogenio da alfafa foi alcançada com a aplicaçăo de 100 a $185 \mathrm{~kg} \mathrm{~K} / \mathrm{haj}$

6. Na auséncia de aplicação de potássio, a alfafa mostrou sintomas visuais de deficiencia desse nutriente, independentemente dos cultivares e dos niveis de cal agem aplicados;

7. As aplicaç̧̃es de calcario e potássio, nos niveis utilizados, promoveram alteraçoes nas concentraçás de macro e micronutrientes, porcentagem de nitrogenio e quantidade total de nitrogenio analisados na parte aerea da alfafa. 


\section{REFERENCIAS BIBLIOGRAFICAS}

ADAMS, F. \& PEARSON, R.W. Crop response to lime in the southern United States and Fuerto Fico. In: PEARSON, R.W. \& ADAMS, F., ed. Soil acidity and liming. Madison, American Society of Agronomy, 1967. cap. 4, p.162-206.

ALCARDE, J.C. Caracteristicas de qualidade dos corretivos da acidez do 5010. In: RAIJ, B. van; BATAGLIA, 0.C.; SILVA, N.M. da, ed. Acidez e calagem no Brasil. Campinas, Sociedade Brasileira de Ciencia do Solo, 1983. p.11-22.

ALLAWAY, H. \& PIERRE, W.H. Availabitily, fixation and liberation of potasssium in high - lime soils. Journal of American Society of Agronomy, Madison, 311940-53, 1939.

ANDFEW, C.S. \& HEGARTY, M.P. Comparative responses to manganese excess of eight tropical and four temperature pasture legume species. Australian Journal of Agricultural Research, East Melbourne, 20: 687-96, 1969. 
ANDREW, C.S. \& ROBINS, M.F. The effect of potassium on the growth and chemical composition of some tropical and temperature pasture legumes. Australian Journal of Agricultural Research, East Melbourne, 20:999-1007, 1969.

ANDREW, C.S. \& THORNE, P.M. Comparative responses to copper of some tropical and temperate pastures legumes. Australian Journal of Agricultural Research, East Melbourne, 13(5):821-35, 1962 .

ARAUJo FILHO, J.A. de; GADELHA, J.A.; PEREIRA, R.M.A.; HAINES, C.E. Competição entre 11 variedades de alfafa (Hedicago sativa L.). Ciencia Agronomica, Fortaleza, $1(2): 81-8$, dez. 1971 .

ARNDN, I. Mineral nutrition of maize. Bern, International Potash Institute, 1975. 452p.

ATTOE, 0.J. Potassium fixation and release in soils occuring render moist and drying conditioning. Soil Science Society of America Proceedings, Madison, 11:145-9, 1946.

BARBARICK, K.A. Potassium fertilization of alfalfa grown on a soil high in potassium. Agronomy Journal, Madison, $77(3): 442-5$, May/June 1985. 
BAssols, P.A. \& PAIM, N.R. Estudo comparativo de cultivares de alfafa (Hedicago sativa L.) introduzidas no Rio Grande do Sul. In: INSTITUTO DE PESQuisas DE zODTECNIA "FRANCISCO 0SoRIO". Anuário técnico - 1978. Forto Alegre, 1978. p.349-417.

BLUME, J.M. \& PURVIS, E.R. Fixation and release of potassium on three coastal plain soils. Journal of Anerican Society of Agronomy, Madison, 31:857-68, 1939.

BOLTON, J.L.; GOPLEN, B.P.: BAENZIGER, H. World distribution and historical developments. In: HANSON, C.H., ed. Alfalfa science and technology. Madison, American Society of Agronamy, 1972. P. 143-66.

BRAUNER, J.L. \& GARCEZ, J.R.B. Lixiviaçăo de potássio, cálcio e magnesio em solos do Rio Grande do Sul submetidos a calagem avaliada em condiçôes de laboratório. Revista Brasileira de Ciencia do Solo, Campinas, 6:89-93, 1982.

BưlL, L.T. Influencia da relação $\mathrm{K} /(\mathrm{Ca}+\mathrm{Mg})$ do solo na produção de matéria seca e na absorço de potássio por graminea e leguminasa forrageira. Piracicaba, 1986. (Doutorado - Escola Superior de Agricultura "Luiz de Queiroz" /USP). 
CAMARGO, D.A. \& RAIJ, B. van. RelaçBes entre aluminio trocável, bases trocáveis e pH em solos. In: CONGRESSO BRASILEIRD DE CIENCIA DO SOLD, 15., Campinas, 1975. Anais. Campinas, Sociedade Arasileira de Ciencia do Solo. 1976. p.95-101.

CARMELLO, Q.A.C. Saturação por bases e relaçỗes entre $k, C a$, Mg no solo na nutrição potássica do milho (Zea nays L.) cv. Piranão. Piracicaba, 1989. 105p. (Doutorado Escola Superior de Agricultura "Luiz de Queiroz"/USP).

CATANI, R.A. \& GALLO, R.J. Avaliação da exigencia em calcário dos solos do Estado de sao Paulo mediante correlação entre pH e a porcentagem de saturaçăo en bases. Revista da Agricultura, Piracicaba, 30:49-60, 1955.

COLLINS, M. \& STANLEY, H. Influence of potassium fertilization rate and form on photosynthesis and N2 fixation of alfalfa. Crop Science, Madison, 21(4):481-5, July/Ago. 1981 .

CRUZ, E.S. \& STAMMEL, J.G. Efeito residual da calagem em solos de diferentes classes texturais. Anuário Técnico do IPZFO, Porto Alegre, 5(1):225-310, ago. 1978. 
DEFELIPO, B.V. \& BRAGA, J.M. Influencia da calagem e fontes de potássio na adsorção de potássio em latossolos em Minas Gerais. Revista Brasileira de Ciencia do Solo, Campinas, $7: 119-22, \quad 1983$.

DEL POZO, M. La alfafa, su cultivo y aprovechamiento. Madrid, Mundi Prensa, 1971. 189p.

FRANCO, A.A. \& DOBEREINEF, J. Especificidade hospedeira na simbiose com Rhizobium - feijao e influencia de diferentes nutrientes. Pesquisa Agropecuária Brasileira, Brasilia, 2:467-74, 1967.

FREITAS, L.M.M. de \& PRATT, P.F. Fiespostas de tres leguminosas à calcário en diversos solas ácidos de são Paula. Pesquisa Agropecuária Brasileira, Grasilia, $4: 89-95, \quad 1969$.

FRIED, M. \& PEECH, M. The comparative effects of lime and gypsum upon plants grown on acid soils. Journal of American Society of Agronomy, Madison, 38(7):614-23, July 1946. 
GOEDERT, W.J.; COREY, R.B.; SYERS, J.K. The effects on potassium equilibria in soils of Rio Grande do Sul, Brazil-Soil Science, Baltimore, 120:107-11, 1975.

GOMES, F.P. Curso de estatistica experimental. 4.ed. São Paulo, Nobel, 1970. 430p.

HANSON, C.H., ed. Alfalfa Ecience and technology. Madison, American Society of Agronomy, 1972. 812p. (Agronomy, 15).

HANSON, A.A., ed. Alfalfa and alfalfa improvement. Madison, American Society of Agronomy, 1988. 1084p.

HAVLIN, J.L. \& WESTFALL, D.G. Potassium release kinetics and plant response in calcareous soil. Soil Science Society of America Journal, Madison, 49:366-70, 1985.

HONDA, C.5. \& HONDA, A.M. Cultura da alfafa. Cambará, IARA Artes Gráficas, 1990. 245p.

JACKSON, T.L.; WESTERMANN, D.T.; MOORE, D.P. The effect of chloride and lime on the manganese uptake by bush beans and sweet corn. Soil Science Society of America Proceedings, Madison, 30(1):70-3, Jan./Feb. 196́. 
JOHN, M.; CASE, U.W.; VANLAERHOVEN, C. Liming of alfafa (Hedicago sativa L.) I. Effect on plant growth and soil properties. Plant and Soil, The Hague, 37:353-61, 1972.

JONES, M.B. \& FREITAS, L.M.M. de. Respostas de quatro leguminosas tropicais a fósfora, potássio e calcário num Latossolo Vermelho-Amarelo de campo cerrado. Pesquima Agropecuaria Brasileira, Brasillia, 5:91-9, 1970.

JONES, M.B.; QuAGLIATO, J.L.; FREITAS, L.M.M. de. Respostas de alfafa algumas leguminosas tropicais a aplicaçós de nutrientes minerais, em trés solos de campo de cerrado. Pesquisa Agropecuária Brasileira, Brasilia, 5i209-14, 1970.

KELLII\&, K.A. \& ERICKSON, T. Efectos que ejerce 1 a fertilización com $P, K$ y $S$ sobre la favorable sementea de Ia alfafa, la supervivencia invernal de las plantas y el rendimento. Revista de la Potassa, Berna, 16(4):3-4, 1984.

KORNELIUS, E. Influéncia da calagem e da adubação fosfatada e potássica na produção da alfafa (Medicago sativa L.) em seis solos do Rio Grande do Sul. Porto Alegre, 1972. 148p. (Mestrado - Universidade Federal do Rio Grande do Sul). 
LEACH, G.L. \& CLEMENTS, R.J. Ecology and grazing management of alfalfa pastures in the subtropics. Advances in Agronomy, New York, 37:127-54, 1985.

LOVADINI, L.A.C.; BULISANI, E.A.; MASCARENHAS, H.A.A. Efeito de niveis de calagen, fósforo e potássio na produçăo de materia seca de soja perene (GIycine wightii) en solos de cerrado. Revista Brasileira de Ciencia do Solo. Campinas, $1: 31-4,1977$.

MAGDORFF, F.R. \& BARTLETT, R.J. Effects of liming acid soils on potassium availability. Soil Science, Baltimore, $129(1): 12-4$, Jan. 1980 .

MAIEF, R.H. \& EARLEY, E.B. The concentration of copper in anatomical parts of several plants. Life sciences, Elmsford, 4(17):1715-9, 1965 .

MALAVOLTa, E. Manual de quimica agricola; nutrição de plantas e fertilidade do solo. Piracicaba. Agronómica Ceres, $1976.528 p$.

MALAVDLTA, E. Elementos de nutriçá mineral de plantas. Piracicaba, Ceres, 1980. 251p. 
MARKUS, D.K. \& BATTLE, W.R. Soil and plant responses to long term fertilization of alfalfa (Nedicago sativa L.). Agronomy Journal, Madison, 57:613-6, 1965.

MCLEAN, E.D. CARBONELL, M.D. Calcium, magnesium and potassium saturation ratios in two soils and their effects upon yields and nutrient contents of german millet and alfalfa. Soil Science Society of Anerica Proceedings, Madison, 36:927-30, 1972.

MEDEIROS, R.B. de \& ZAMBRA, J.E.G. Rendimento de materia seca de cultivares de alfafa na regiăo das Missరes/Rs. In: COTRIJUI - Resultados de experimentação e pesquisa no CTC - 1976-86. Ijui, 1987. P.182-7.

MICHAUD, F.; LEHMAN, W.F.; RUMBAUGH, M.D. World distribution and historical development. In: HANSON, A.A., ed. Alfalfa and alfalfa improvement. Madison, American Society of Agranomy, 1988. p.25-91.

MIELNICZUK, J. Formas de potássio en solos do Brasil. Revista Brasileira de Ciencia do Solo, Campinas, 1:55-61, 1977. 
NUERNBERG, N.J. Técnicas de produçăo da alfafa. In: CONGRESSO BRAsileiro DE PAstagens, $n$ 으. 8., Piracicaba, 1986. Anais. Firacicaba, FEALQ, p.145-60.

QLIVEIRA, P.R.D. de; \& CORSI, M. Avaliaçăo da produção e da qualidade de cultivares de alfafa (Hedicago sativa L.). Revista da Sociedade Brasileira de Zooteenia, Viçosa, $16: 382-93,1987$.

OLIVEIRA, P.R.D. de. Avaliação da produção e da qualidade de cultivares da alfafa (Hedicago sativa L.). Piracicaba, 1986. 75p. Mestrado - Escola Superior de Agricultura "Luiz de Queiroz"/USP).

QVELETTE, G.J. \& DEssuREAUX, L. Chemical composition of alfaifa as related to degree of tolerance to manganese and aluminium. Canadian Journal of Plant Science, Ontario, $38: 206-14,1958$.

PEAA, J.A.G. Cálcio, magnesio $e$ potássio no solo $e$ em plantas de algodão, utilizando magnesita calcinada e cloreto de potássio, em tress niveis de calagen. Viçosa, 1991. 79p. (Mestrado - Universidade Federal de Viçosa). 
QUAGGI0, J.A. Resposta das culturas a calagem. In: SEMINARIO SOBRE CORRETIVOS AGRICOLAS, Piracicaba, 1984. Campinas, Fundação Cargill, 1985. Cap.4, p.123-54.

RAIJ, B. van; SILVA, N.M. da; BATAGLiA, D.C.; QUAGgio, J.A.; HIROCE, R.; CANTARELLA, H.; BELLINAZZI Jr., R.; DECHEN, A.F.: TRANI, P.E. Recomendaçöes de adubaçăo calagem para - Estado de Sáo Paulo. Campinas, Instituto Agronómico de Campinas. 1985. 107p. (IAC. Boletim Tecnico, 100).

FAIJ, B. van. Fertilidade do solo e adubaçáo. Să Faulo, Agronomica Ceres; Piracicaba, Associação Brasileira para Pesquisa da Potassa e do Fosfato, 1991. 343p.

RAIJ, B. van. \& CAMARGO, O.A. Influencia das bases trocáveis na lixiviação de potássio en colunas de solos. In: CONGRESSO BRASILEIRO DE CIENCIA DO SOLO, 14., Santa Maria, 1973. Anais. Santa Maria, Sociedade Brasileira de Ciencia do Solo, 1974. p.263-8.

RAIJ, B. van; QUAGgIo, J.A.; CANTARELA, H.; FERREIRA, M.E.; LOPES, A.S.; BATAGLIA, Q.C. Análise química do solo para fins de fertilidade. Campinas, Fundação Cargill, 1987. $170 \mathrm{p}$ 
RANDO, E.M. Desenvolvimento da alfafa (Hedicago sativa L.) em diferentes níveis de $\mathrm{pH}$, potássio e enxofre no solo. Piracicaba, 1992. 220p. (Doutorado - Escola Superior de Agricultura "Luiz de Queiroz"/USP).

RICCI, M.S.F.; DEFELIPO, B.V.; COSTA, L.M.; REZENDE, S.B. As fraçós granulometricas do solo como reserva de potássio para as plantas. Revista Brasileira de Ciencia do solo, Campinas, $13: 181-6,1989$.

RITCHEY, K.D. O potássio nos oxissolos e ultismolos dos trópicos áridos. Piracicaba, POTAFos, 1982. 69p. (Boletim Tecnico, 7).

ROBSON, A.D. \& LONERAGAN, J.F. Sensitivity of annual Hedicago species to manganese toxicity as affected by calcium and pH. Australian Journal of Agricultural Research, East Melbourne, 21(8):223-32, 1970.

SAIBRO, J.C. de. Produção de alfafa no kio Grande do Sul. In: SIMPOSIO SDBRE MANEJO DE PASTAGENS, 7. ., Piracicaba, 1985. Anais. Piracicaba, FEALQ, 1985. p.61-106. 
SAIBRO, J.C. dE.; MARASCHIN, G.E.; BARRETO, I.L.; STAMMEL, J.G.; GOMES, D.B.; Avaliaçăo preliminar de cultivares de alfafa (Hedicago sativa L=) no Rio Grande do Sul. In: UNIVERSIDADE FEDERAL DO RIO GRANDE DO SUL. Faculdade de Agronomia. Relatorio de pesquisa, 1965/71. Porto Alegre, 1972. P.57-60.

SANZONOWICZ, C. \& VARGAS, A.A.T. Efeito do calcário e do potássio na produção e na composição química do stylosanthes guyanensis em um latossolo vermelho-escuro. Revista Brasileira de Ciencia do Solo, Campinas, 4:165-9, 1980 .

SARRUGE, J.R. \& HAAG, H.P. Analises quimicas en plantas. Piracicaba, ESALQ, 1974 . 56P.

SCHULTE, E.E. \& COREY, R.B. Extraction of potassium from soils with sodium tetraphenyl-borom. Soil Science Society of America Proceedings, Madison, 29:33-5, 1965.

SILVA, N.H.; CARVALHQ, L.H.; HIROCE, R.; KONDO, T.I. Resposta do algodoeiro à aplicação de calcário e de cloreto de potássio. Bragantia, Campinas, $42(2): 643-58$, 1984 . 
SILVA, R.B.V. \& STAMMEL, J.C. Informe preliminar abre o efeito da aplicaçăo de calcário, fósforo e potássio no estabelecimento de alfafa (Hedicago sativa L.) nun solo ácido do Rio Grande do Sul. Porto Alegre, UFRGs/ Faculdade de Agronomia e Veterinária, 1969. 53p.

SIQUEIRA, O.J.F. de., cood. Recomendaçáo de adubaçăo e calagem para os estados do Rio Grande do gul a Santa Catarina. Fasso Fundo, EMBRAPA/CNPT, 1987. 100p.

STAMMEL, J.G. \& KORNELIUS, E. Efeitos da aplicação de KCl sobre a produção de alfafa e propriedades químicas de solos do Rio Grande do Sul. Agronomia Sul Riograndense, Porto Alegre, $9(1): 71-84,1973$.

WASSERMANN, U.D. \& BERG, M. van den. Comparative response of lucerne (Hedicago sativa L.) and sainfoin (Onobrychis vicia folia Scop.) to applications of $F, K$ and $l i m e$. South African Tydskr Plant Grond, Pretoria, 7(1):76-80, 1990.

WERNER, J.C. Adubaçao de pastagens. In: ENCONTRO DE ATualizaça EM PAstagens, 1, São Faulo, 1977, p.43-63. 
YAMADA, T. Potássio: funçăes na planta, dinámica no solo, adubos e adubação potássica. In: CURSO DE ATUALIZAçAo EM FERTILIDADE DO SQLO SOB CONDIÇOES DE CULTIVO REDUZIDO. Santa Maria, 1986. Anais. Santa Maria, Universidade Federal de Santa Maria, 1986. P.Kz-K21.

YAMADA, T. Potássio: dinámica e disponibilidade no solo. In: CURSO DE ATUALIZAÇX̃D EM FERTILIDADE DO SOLO, I Iha Solteira, 1987. Campinas, Fundação Cargill, 1987. P. 183-201.

YORK JT.. E.T. \& ROGGERS, H.T. Influence of lime on the solubility of potassium in soils and on its availability to plants. Soil Science, Baltimore, 63:467-77, 1947.

YORK JF., E.T.; BRADFIELD, R.; PEECH, G.M. Calcium-potassium interactions in soils and plants: I. Lime-induced potassium fixation in mardin silt loam. Soil Science, Baltimore, $77(1): 379-87$, Jan. 1954a.

YORK Jr., E.T.; BRADFIELD, R.; PEECH, Q.M. Influence of lime and potassium on yield and cation composition of plants. Soil Science, Baltimore, 77(1):53-63, Jan. 1954b. 